\title{
Poplavna ravnica reke Save na Krškem polju kot gospodarsko zaledje kmečkih gospodarstev v prvi polovici 20 . stoletja
}

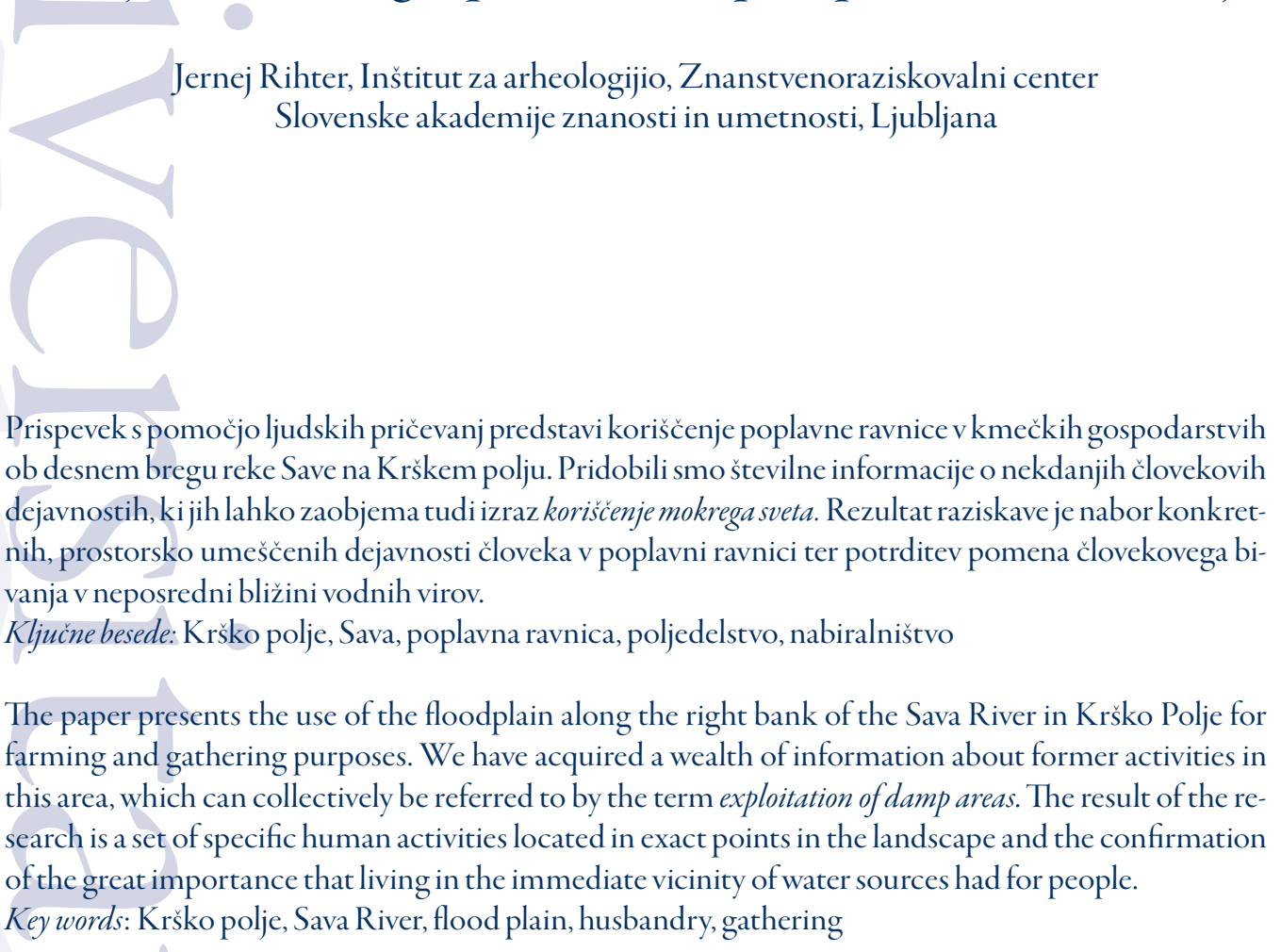

$\mathrm{P}$ regled človekovih dejavnosti $\mathrm{v}$ poplavni ravnici temelji na ljudskih pričevanjih, ki se nanašajo na prostor med reko Savo in vasmi med Drnovim in D. Skopicami na Krškem polju. Gre za razširjeno nadaljevanje podobno zasnovanega dela, ki obravnava različne vidike človekove povezanosti s poplavno ravnico na območju G. in D. Skopic (Rihter 20Io). Ta je temeljil na popisu izbranih kulturnih in naravnih posebnosti na tem istem območju (Rihter 2007), idejno pa na pripovedih Uršule Vodopivec in na njeni kasnejši knjigi spominov (2008). ${ }^{2}$ Večina pričevanj in izročil, zabeleženih na raz-

I Podatke zbiram avtor tega prispevka, ki hranim celoten arhiv pričevanj in izročil. Informatorji so označeni s naključno tričrkovno oznako.

2 Uršula Vodopivec: Knjiga spominov »Za Jerneja« 2008 (rokopis); obseg 145 str., format As (neobjavljeno) (gl. Literatura). Posamezni izseki iz strani p. 33, p. 37, p. 64-72 in p. 90 , so bili objavljeni pri Rihter (2010). lične medije, je bilo nesistematično zbranih med leti 2004-2016. ${ }^{3}$ Sredi leta 2016, ko je bila zaključena neobjavljena različica pričujočega prispevka, je celotno območje raziskave zajela izgradnja zajezitvenega bazena za HE Brežice. Pri tem je prišlo do popolne spremembe obrečnega okolja celotnega območja, ki nas $\mathrm{v}$ tej raziskavi najbolj zanima. Zato naj bralec različna sklicevanja in lociranja $\mathrm{v}$ prostoru na topografski podlagi (Sl. I), v naravi razume v kontekstu stare savske struge pred letom 2016/2017, torej pred zajezitvijo. Zbirka podatkov in s tem tudi pričujoče delo, je bilo kasneje dopolnjeno z novimi pričevanji, zbranimi vključno do julija 2019.

Zbranih je bilo več stotin živih toponimov. Med njimi so številni še danes v uporabi, mno-

\footnotetext{
Raziskovanje življenja s poplavno ravnico izvajam avtor zapisa.

$\mathrm{Za} \gg z ̌ i v e \ll$ toponime štejem tiste, ki so bili zbrani preko ustnih virov in jih je bilo moč z informatorji tudi locirati. Približno petina vseh
} 
go pa je takih, ki so iz uporabe prešli s komasacijo kmetijskih zemljišč. Do leta 2014 je bilo celotno območje, $\mathrm{z}$ dragoceno izjemo $\mathrm{I}, 5 \mathrm{~km}^{2}$ polja pod vasjo Drnovo (gl. Paša ...), že v celoti komasirano (Rihter 2015, II-I5). Navkljub temu je bilo možno vse toponime, tudi takšne, ki so po komasaciji izšli iz redne uporabe, $\mathrm{z}$ informatorji zbrati, preveriti ter $s$ pomočjo starejših ortografskih posnetkov prostorsko umestiti in prenesti na topografsko podlago. $\mathrm{V}$ naši raziskavi nastopajo le tisti toponimi, na katere je vezana informacija o človekovih dejavnostih. Vsak toponim, ki ga omenjamo, je umeščen na topografski karti v merilu I: 25000 (Sl. I) in sicer pod tekočo številko od I-II 4. Vrstni red številk toponimov sledi prvi omembi toponima $\mathrm{v}$ tekstu.

Velika količina toponimov za prostor, ki skozi današnjo gospodarsko perspektivo nima več posebnega pomena, priča o tem, da je bilo $\mathrm{v}$ preteklosti drugače. Razvidno je, da so bila v prvi polovici 20. stoletja še vsa zemljišča poplavne ravnice poimenovana, kar implicira njeno pomembnost za človeka oziroma njegovo vsakdanjo prisotnost $\mathrm{v}$ njej.

Nekatera pričevanja so unikatna, druga je bilo moč preveriti pri več informatorjih. Za mnoge dejavnosti najdemo primerjave $\mathrm{v}$ drugih primerljivih okoljih, vendar njihovo navajanje ni predmet tega prispevka. Podajamo jih le v primerih, ko želimo osvetliti kakšno izmed manj jasnih trenskih informacij ali pa kadar želimo bralca napotiti na lokalno zadevne primerjave. Drobci raznovrstnih pričevanj o človekovih dejavnostih $\mathrm{v}$ tem delu poplavne ravnice, so bili objavljeni na več mestih (Rihter 2006; isti 2008; isti 20I0; isti 20II; isti 2014; isti 2015).

V zvezi s tem izpostavimo delo Življenjepisi Štajercev in Kranjcev ob sotočju rek Krke, Save in Sotle (Iz časov jećmenove kave) avtorice Ivanke Počkar (1998), ki s podatki v obliki ljudskih pričevanj sega tudi v neposredno soseščino našega interesnega območja. Med njimi so nekatere locirane tudi v poplavni obrečni svet spodnjega Posavja (Počkar 1998, 46-313, passim).

toponimov je del avtorjevega lastnega/vaškega/topografskega repertoarja, kot domačina.
Zbrana je bila velika količina prvoosebnih pričevanj o nekdanji izrabi poplavne ravnice, kot pomembnem gospodarskem zaledju tukajšnjih kmetij. Predvsem izstopajo podatki o koriščenju mokrega sveta. Pri tem se je porodilo vprašanje, kako je mogoče, da so bili informatorji, rojeni v prvih štirih desetletjih 20. stoletja, še priča povsem drugačni podobi poplavne ravnice, kot bi jo pričakovali, navkljub sto let poprej pričeti savski regulaciji? Del odgovorov je ponudil pregled zgodovine regulacijskih del in drugih podatkov, ki se nanašajo na prostor reke Save med Krškim in Brežicami v 19. in 20 stoletju (npr. Kronberg I839; Costa I848; Lapajne I894; Vrhovec I895; Teppey 1977; Umek 1986 in 1996; Verbič in Berič 1993; Ripšl 2007; Šebek 2009, Počkar 2009; Mlekuž 2009; Rihter 2015 in 2016a-d), del pa usmerjeno spraševanje informatorjev o izgle$\mathrm{du}$ in izrabi različnih predelov poplavne ravnice $\mathrm{v}$ času pred letom $194 \mathrm{I}^{5}$ (Rihter 2007; isti 20ıo; isti 20I5; glej dalje). Izkazalo se je, da je šlo za čas, ko so leta I 829 pričeta regulacijska dela na reki Savi med Krškim in Brežicami trajala že več kot sto let, utrditvena dela pa so bila še vedno v teku (Rihter 2015, 6I-62; Teppey 1977, 29). Dokončna izravnava struge oz. njena ustaljenost $\mathrm{v}$ poteku, ki je podoben današnjemu, ${ }^{6}$ pa je bila izvedena šele do leta 1945 (Šebek 2009; Rihter 2015; 2016a, 59) oz. do druge polovice 20. stoletja (Verbič 2008, 38; prim. Teppey 1977, 29). Regulacija je porušila nekdanji naravni ekosistem, ki se je od današnjega, antropogenega precej razlikoval (Verbič in Berič 1993,333 ).

Zaradi neposrednih vezi informatorjev, rojenih $\mathrm{v}$ prvi polovici 20 . stoletja, $\mathrm{z}$ generacijami (starih) staršev rojenimi v 2. pol. 19. stoletja in njihove navezanosti na iste prostore $\mathrm{v}$ poplavni ravnici, lahko danes, na pragu tretjega tisočletja, ko (ravnica) ni več ohranjena $v$ tedanji obliki, razpolagamo z zelo konkretnimi pričevanji o postopnih spremembah obrečnega okolja in hkrati o spremenjenih dejavnostih človeka v njem.

5 Letnicaje okvirni mejnik, ki ga predstavlja internacija krškopoljskega prebivalstva v nemška taborišča. Ta je pri večini pripovedovalcev potekala v zadnji tretjini leta I94I in v prvih dveh mesecih leta 1942. Mišljeno za podobo struge, ki je tu obstajala do leta 2015/2016 pred pričetki del za HE Brežice. 
Današnje korito Save je umetno in seka meandre iz različnih zgodovinskih obdobij. Navkljub temu je reka pogosto poplavljala na jugovzhodnem območju Vrbine (Verbič 2004, I85, S1. 2). Hidrotehnični ukrepi so le počasi vplivali na številčnost poplav in na mrtvice ter seveda na gladino talne vode. Odziv na spremenjeno stanje rečnega toka se je mdr. razmeroma hitro kazal na rastju, tudi v rečnem zaledju in posledično $\mathrm{v}$ načinu človekove izrabe mokrega sveta. Z leti je Sava lastno korito poglabljala, s tem pa tudi nivo talne vode v vodonosniku. Seveda je vse postopne spremembe najprej zaznal in spremljal tukajšnji človek, saj je bil s poplavno ravnico tedaj življenjsko še povezan. Po letu I94I je ta sodvisnost plahnela, vendar je bila tedaj še prvi dve povojni desetletji izrednega pomena.

Iz pričevanj je možno povzeti in nanizati poglavitne mejnike v razvoju obsavske pokrajine v njenem poregulacijskem obdobju. Tako je bil v vseh vaseh še zabeležen spomin na rečno plovbo, ne le splavarjev, ki so delovali še dolgo v 2o. stoletje, temveč tudi na mnogo starejšo ladijsko plovbo, ki naj bi se po zgodovinskih virih okvirno zaključila leta I862 (Lapajne I894, Vrhovec I895) in $\mathrm{z}$ njo povezanimi pričevanji o poteku vlečnih poti, potrebami po živini, pletenju vlečnih vrvi, ipd. Sledijo pričevanja o regulaciji in izgradnjah regulacijskih arhitektur, med katerimi npr. Petrova škarpa na Vihrah dokumentirano sega še pred sredo 19. stoletja (Rihter 2016a-c). Predvsem $\mathrm{v}$ vzhodni polovici obravnavanega prostora v prvih desetletjih 20. stoletja opisujejo izjemno plitvost novoizkopanega savskega korita predvsem med Skopiškim zalivom in nekdanjo vasjo Zasavje (Rihter 2015, 272). To se sklada s pričevanji o pogostem prestopanju bregov reke na tem odseku in posledično o angažiranju delavcev $v \mathrm{t}$. i. savski službi, ki je skrbela za utrjevanje razritih bregov in za izdelovanje raznovstnih vrbovih fašin (Rihter 2010, 2016a, b, c).

Človekovo koriščenje mokrega sveta se je zmanjševalo z stabilizacijo savskega korita in postopoma jenjalo, sledeč spremenjenim razmeram pa se je tudi prostorsko premikalo. To se kaže v pričevanjih o starih in novih lokacijah opravlja- nja kakšne izmed dejavnosti. Takšna so npr. pričevanja o starih periščih na Mrtvicah ali o starih pašnih območjih za prašiče na brižanskem (gl. Mokri svet vrbine). O podobni (čeprav natančneje nedatirani) dinamiki govori tudi del toponimov, kot so Stari vrti, Brodišče, Stare gmajne, Turški brod, idr. Zadnjo večjo spremembo so v vaseh zaznali po izgradnji jezovne zgradbe za NE Krško, ko so presahnile še zadnje delujoče štirne, saj se je od jezu dolvodno, savsko korito dodatno poglobilo in s tem tudi vodostaj talne vode. Njen nivo se je v zaledju ponovno zvišal po izgradnji nove jezovne zgradbe za HE Brežice v letu 20I8, ko so prebivalci zaznali pojave talne vode $\mathrm{v}$ gramoznicah in strugah, tudi tam, kjer poprej do tega ni prihajalo.

V kolikor strnemo, je v začetni fazi neuspešna savska regulacija (Rihter 20I5, 6I-69) podaljšala obdobje nekaterih možnosti izkoriščanja $\mathrm{z}$ vodno prisotnostjo povezanih zemljišč, še za eno stoletje, in sicer najmanj do pričetka 2. svetovne vojne, ponekod, v omejenem obsegu pa še dlje. Tako je poplavna ravnica v prvi polovici 20. stoletja marsikje, zlasti pa na območju Gorenjih in Dolenjih Skopic še vedno kazala podobo, ki je ohranjala številne naravne elemente značilnejše za čas pred regulacijo, čeprav so ti ravno tedaj že pospešeno izginjali (Rihter 20IO). Biodiverziteta takšnega okolja je bil izjemna, vendar je v poregulacijskem obdobju prišlo do njenega osiromašenja, ki ga je pospešila človekova povojna vrnitev $\mathrm{v}$ poplavno ravnico, ki je bila agresivnejša kot poprej, predvsem pa mehanizirana ter motivirana $v$ duhu intenzivne gospodarske izrabe.

To spoznanje je pomenilo potrditev, da je na terenu še možno pridobiti kvalitetna, prvoosebna in prostorsko umeščena pričevanja o podobi poplavne ravnice pred letom I94I in o načinih njenega neintenzivnega koriščenja. Pričujoče delo sledi predpostavki, da v kolikor naravne danosti pri naselbinah in njenih radijih niso nepomembne, po tem nas za določeno obdobje nujno zanima, kakšne so bile te naravne danosti in predvsem, katere od teh je človek dejansko izkoriščal. Nabor vedenj, ki izhaja iz obeh možnosti 
pa nam prejkone odpira globlji vpogled v zgodovino prostora in človeka.

\section{Kulturne in naravne danosti}

$S$ širšega prostora obravnavanih vasi so znane prazgodovinske, rimske in zgodnjesrednjeveške arheološke najdbe (Petru in Petrui978; Bavec 2006; 2009, 57-63). Te kažejo na intenzivno, še zlasti rimskodobno poselitev. Tod namreč vodi trasa rimske itinerarske ceste, ob kateri je na območju današnjega Drnovega stalo antično mesto Neviodunum (Petru 1978). Prve pisne omembe imen današnjih vasi sodijo $\mathrm{v}$ čas od srede I4. do srede I5. stoletja (Mlinarič 1977, 26-28, 44), ko se, najbrž že na robovih poplavne ravnice, prvič omenjajo predhodnjice kmetij v današnjih vaseh. Dandanes jih druži lega natnačno ob robu poplavne ravnice, katere značilnost je prepredenost z opuščenimi, pretežno meandrirajočimi rečnimi tokovi. Zato so njeni robovi oblikovani kot meanderski loki (Verbič 2004, I84-I85). To je hkrati tudi najbolj očitna morfološka razlika, ko poplavno ravnico primerjamo z zgornjepleistocensko teraso, ki je zaradi človekove dalj časa trajajoče obdelave navidez že povsem ravna (Verbič 2004, 184-185).

Sledi opis nekaterih geoloških značilnosti območja, zato ponovno spomnimo, da z izrazom poplavna ravnica $v$ pričujoči obravnavi označujemo v najširšem smislu območje tukajšnjih holocenskih savskih teras, imenovanih Vrbina/e. Ta zemljišča so bila $\mathrm{v}$ naravnem stanju večkrat poplavljena, zaradi človekovih posegov $\mathrm{v}$ rečno strugo pa dandanes ob povodnji vse terase niso poplavljene. Za polje nad poplavno ravnico, ki ga povodenj v holocenu praviloma ni dosegala, $\mathrm{v}$ geologiji zaobjema poimenovanje zgornjepleistocenska terasa. V nadaljevanju krajše, tudi pleistocenska terasa.

Razen G. in D. Skopic, vse vasi stojijo na pleistocenski terasi, oziroma natančneje, na skrajnem robu zgornjepleistocenskega prodnega zasipa (gl. Verbič 2004, I84-I84). Krško polje je namreč prekrito $s$ prodnimi savskimi zasipi različnih starosti (Verbič 1993, 327). V zadnji (zgornjepleistocenski) prodni zasip ledene dobe, pa je reka Sava urezala še holocenske terase, ki so po nastanku erozijske površine (Verbič 1993, 327330; 2004, 185, gl. Stritar 1977, 627-638).

Tako je med holocenskimi in zgornjo pleistocensko teraso nastala značilna več metrov visoka višinska razlika, ki je najočitnejša za vasi na razdalji med Drnovim in Vihrami. $S$ tem vasi višinsko dominirajo nad poplavno ravnico. Obrežna narava vasi in sama dvojnost zgoraj/spodaj $v$ odnosu do poplavne ravnice, se dodatno izraža $\mathrm{v}$ pedoloških in posledično $\mathrm{v}$ agrarnih danostih teh vasi.

Z vidika kmetijstva se v podsekvenci na produ in pesku pojavljata dve združbi tal in sicer na holocenskih terasah združba obrečnih tal in na pleistocenski terasi združba rjavih tal. Naravna meja med njima zato poteka po ježi, ki deli holocensko območje od pleistocenskega. To pa je istočasno meja, ki deli združbo obrečnih tal od združbe rjavih tal (Stritar 1990, 52-53; 1977, 636-637). Ljudska prostorska delitev vaško polje npr. na Drnovem, loči na delenske in gorenske njive, kjer za slednje velja tudi krajše poimenovanje pule ali na pul. Pule je tu sinonim za njive na pleistocenski terasi. V obravnavi bomo za slednje uporabili izraz zgornje polje, za njive na holocenskih terasah, ki so bile izkrčene v poplavni ravnici, pa spodnje polje (Sl. 2).

Ta delitev ima v lokalni rabi (in v zavesti) že vgrajeno pomensko informacijo o rodovitnosti ali bolje rečeno o stanovitnosti spodnjega polja, ki se bolj obnese tudi v primeru suše. Čeprav sta obe polji v osnovi rodovitni, je splošno znano, da huda suša na zgornjem polju lahko uniči skoraj celoten pridelek. Nasprotno pa je možno v spodnjem polju sočasno celo spraviti nekaj pridelka. Prav tako pa je bilo lahko spodnje polje ponekod premokro za posevke ali pa nepričakovano poplavljeno v času žetve ali spravila. ${ }^{7}$ Zgornje polje je zaradi plitve ornice hitro odcedno in je zato bolj podvrženo suši, med tem, ko je spodnje polje večinoma vlažnejše in bolje kljubuje suši. Vladala je torej izrazita dvojnost, posledično tudi v dodatnih znanjih potrebnih za uspešno obdelavo. Staro pravilo, ki je nekdaj npr. veljalo na Bre-

Informator EKC, VER, TTD, STM. 
gah, se glasi »gor 12 , dol $16 \ll^{8}$, ki pove kako globoka naj bo brazda $(\mathrm{cm})$ v zgornejm in spodnjem polju, da s preglobokim oranjem v plitvo ležečo prodno osnovo ne bi trajno uničili njive.

V času do leta 194I, ko je bilo preživetje večine tukajšnjih prebivalcev odvisno skoraj izključno od uspešnosti poljedelstva, se takšna možnost gospodarjenja v obeh ekoloških conah izkazuje kot ključna, sama lega naselbin pa namerna, premišljena in predvsem ključna za preživetje. Vstran gospodarskemu vidiku, lahko poselitev robov poplavne ravnice pomeni tudi izraz identitete naseljencev (Evans 2003, 90). Navkljub temu pa so obrečne poplavne ravnice $v$ modernem gospodarstvu navadno obravnavane kot prostor drugotnega pomena (Brown 200I, 282).

$\mathrm{Za}$ razumevanje pomena človekovega bivanja na stiku dveh ekoloških con in gospodarskega pomena poplavne ravnice, je izjemno prikladno dejstvo, da so kar štiri od šestih obravnavanih vasi (z izjemo G. in D. Skopice), imele leta 1824 jedra svojega spodnjega polja skoraj v celoti znotraj k. o. Drnovo. Ta s svojim obsegom -842 ha spodnjega polja na razdalji do Save in le z 230 ha zemljišči na zgornjem polju - posredno izpostavlja in poudarja obrežno naravo obravnavanih vasi, hkrati pa v celoti zaobjema njihov gospodarski radij v poplavni ravnici. Cenilni elaborat franciscejske katastrske izmere za k. o. Drnovo, je posledično dober vir vpogleda za razumevanje gospodarjenja $\mathrm{v}$ poplavni ravnici. Tam izvemo, da so najboljše njive $\mathrm{I}$. in 2 . kakovostnega razreda vzorčili le $\mathrm{v}$ spodnjem polju (v poplavni ravnici), med tem, ko so njive 3 . kakovostnega razreda beležene $\mathrm{v}$ zgornjem polju. Za razliko od zgornjega polja, so v spodnjem polju, poleg njiv, obstajali še različni kakovostni razredi travnikov in pašnikov. Pašniki nasploh najbolj karakterizirajo območje naše obravnave, saj jih na zgornjem polju skorajda ni bilo. Obstajala je tudi kategorija - trike (Rihter 2015, 16-27). Trike (Trischacker) so bila zemljišča, kjer je šlo za izmenjevanje njive in pašnika na istem mestu (Seručnik 2009, 494) oz. za daljšo dobo počivanja zemljišča, kot pri običajni prahi (Valenčič
1970, 132; prim. Novak 1947, IO-II). V poplavni ravnici je bilo takšnih zemljišč za dobrih 85 ha in sicer na prehodnih območjih med strnjenimi pašniki in njivami, kjer je šlo za naosemletni kolobar brez gnojenja. Prvo leto so sejali proso, drugo leto oves in sirek, tretje leto so površino uporabljali kot pašnik in tako še nadaljnih pet let, ko se je kolobar ponovil (Rihter 2015, 19-25). V zvezi s kvaliteto spodnjega polja je izpoveden podatek za k. o. Drnovo, ki se nedolgo (leta i833) pred zemljiško odvezo, omenja kot ena redkih k. o. na območju davčnega okraja Šrajbarski turn, kjer so v dobi uvajanje koruze, le-to sejali v večjih količinah (Britovšek 1964, 215-217). Pomenljivo pa je, da se je sejala praviloma na najkakovostnejših njivah I. in 2. kakovostnega razreda, torej skoraj izključno na spodnjem polju, ki je dajalo največji pridelek (Rihter 2015, 17-19). S tem je spodnje polje na našem prostoru postalo ključen nosilec tudi pri uvajanju novih poljščin, ki so trajno spremenila dotednje poljedelske prakse. Tako naprimer že v sosednji katastrski občini Senuše, koruza v istem času sploh še ni bila del katastrske cenitve, saj so jo sejali le v manjši meri (Rihter 2014, I5).

Retrogradna analiza zemljiškega katastra za vas Drnovo (Rihter 2015), je pokazala, da so bila najstarejša in najkvalitetnejša obdelovalna jedra zgornjega in spodnjega polja med predhodnjice nekaterih današnjih kmetij razdeljena v uravnoteženih deležih. Po nastanku relativno najmlajše kmetije so v teh jedrih praviloma odsotne ali pa nastopajo prostorsko povsem obrobno, nekatere pa si v i9. stoletju krčijo dodatne deleže na izrazito mladih, obrečnih tleh globoko v poplavni ravnici (Rihter 2015, I-I63). Zemljišč naj bi namreč v nižinskem uradu Krškega gospostva primanjkovalo že v zadnji tretjini I6. stoletja (Koropec 1977,48$)$. Isti čas je zabeleženo tudi največje število govedi in konj, ravno v vaseh, ki obdajajo poplavno ravnico ob levem in desnem bregu Save (Koropec 1977, 48-49). Sklepamo lahko, da je bilo tako zaradi bogatega pašnega in vodnatega zaledja, ki so jih te vasi, za razliko od preostalih, imele $\mathrm{v}$ poplavni ravnici. 


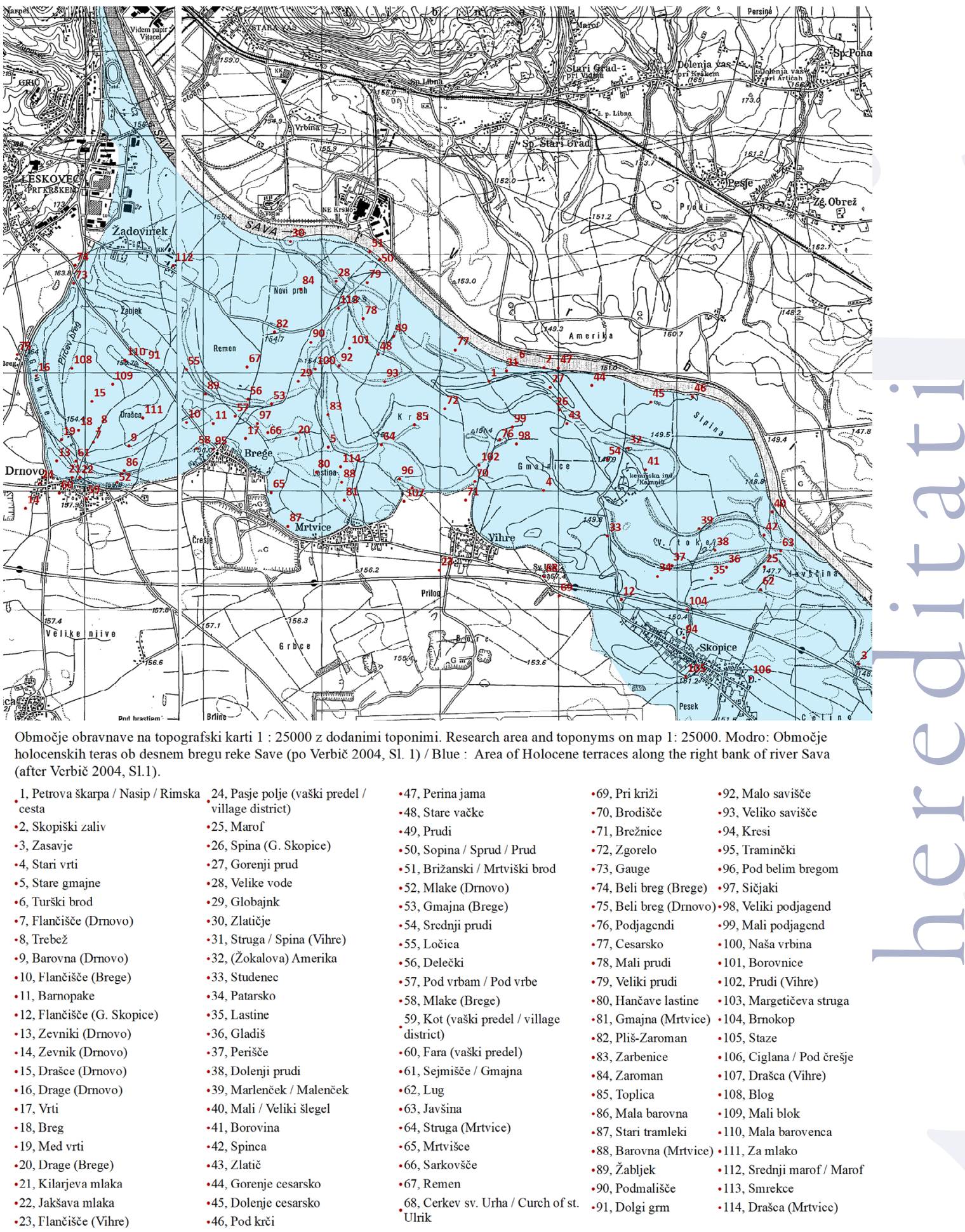

Slika r: Prostor obravnave. / The territory of inquiry. 


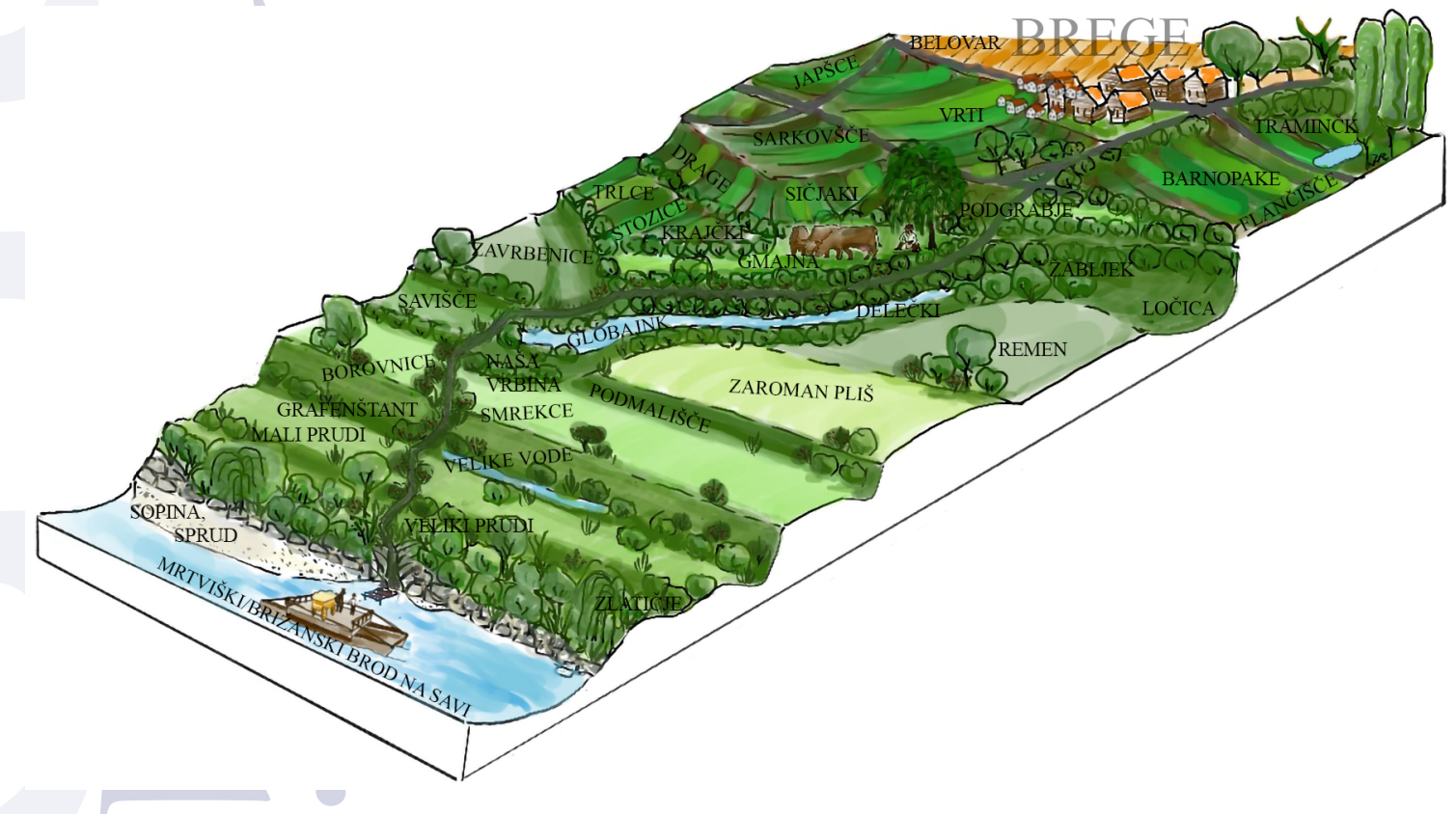

Slika 2: Ilustracija presekov savskih teras in idealizirana podoba vaškega polja vasi Brege do reke Save v prvi polovici 20. stoletja. / Idealized illustration of terraces of the Sava river and its cross-section in the area of fields that belonged to the Brege village as they were in first half of $20^{\text {th }}$ century (ilustrirala: Janja Rihter).

Gre za ekološko povsem različna svetova; med tem, ko je bilo zgornje polje v začetku i9. stoletja' skoraj v celoti namenjeno zgolj njivam, bi spodnje polje lahko imenovali tudi kot prostor med vasjo in reko, kjer je poleg izkrčenega sveta njiv, travnikov in pašnikov do srede 20. stoletja obstajalo še veliko drugih naravnih oblik značilnih za vlažno/mokro okolje; npr. mrtvice, vlažni travniki, logovi, loke in t. i. vrbine na nekdanjih prodnatih otokih (Sl. 2). Poplavna ravnica prepredena s starimi strugami reke Save ni bila nikoli povsem izkrčena v polje, krčenje obdelovalnih površin pa poteka še danes (Rihter 2015, 59-60; sl. 23 in 24).

$\mathrm{Na}$ ravni kmečkih gospodarstev, je človekove dejavnosti v poplavni ravnici težko ločiti na agrarne in neagrarne. V skoraj vseh primerih je šlo za kombinacijo obojega $\mathrm{z}$ namenom zagotavljanja uspešnejšega preživetja. Različne dejavnosti so bile močno prepletene tako prostorsko kot časovno. V opish v nadaljevanju bo večkrat razvidno, da so $\mathrm{v}$ poplavni ravnici sočasno potekala številna, povsem različna dela, npr. paša, napajanje, ribolov, pranje tkanin in spiranje žita.

$\mathrm{V}$ nadaljevanju prehajamo na konkretne opise človekovih dejavnosti v poplavni ravnici.

\section{Poplavna ravnica kot gospodarsko zaledje kmečkih gospodarstev}

Predstavitev pomena poplavne ravnice pričenjamo s tamkaj površinsko eno najmanjših, obdelovalnih enot im. - flančišče. Ta s svojo izrazito navezanostjo na poplavno ravnico, pravzaprav najbolj pooseblja in združuje bistvo življenja na robu dveh ekoloških con in poudarja njegov pomen za preživljanje človeka. Predvsem pa kaže na njegovo premišljeno prostorsko palnirano kmetijstvo. 


\section{Flančišča}

Flančǐšč $a^{\text {I0 }}$ so bila najmanjše obdelovalne enote izven domačega dvorišča, izrazito vezane na pašnike in njihova obrobja $\mathrm{v}$ poplavni ravnici. Navadno jih neposredno izdaja mikro toponim Flančišče, ki se nahaja znotraj območja, ki ga sicer pokriva nek drug, površinsko obsežnejši toponim. Flančišče/a niso enaka vrtu oz. gredi, ki je bila vezana na domače dvorišče, niti njivi $s$ (po)vrtninami, t. i. zeljnikom, ki je po sestavi posevkov dejansko razširjen vrt, le da se lahko (od doma) nahaja na do nekaj sto metrov oddaljeni rodovitnejši njivi. Flančišča zato morda najbolje opredeljuje izraz gojitveni vrt, kot prostor za vzgojo in množenje rastlin, ki so jih kasneje presajali na njive/vrtove na različnih delih polja.

Flančišča so obujali v zgodnji pomladi, na njih pa so največ gojili sadike zelja in pese. $V$ času po presaditvi na njive (Gl. Ilovica), so flančišče, do drugega leta povsem opustili, nato pa zopet iskali novo rodovitno mesto za sejanje, občasno pa so ponovno obudili tudi staro mesto. Pri tem je šlo za izkoriščanje določenih predelov pašnikov na najrodovitnejših mikrolokacijah, ki jih danes lahko naznanja toponim Flančišče (Rihter 2015, 24-25). Pogosto je šlo za poraščene predele, ki jih je bilo potrebno v celoti ali deloma izkrčiti. ${ }^{I I}$ Preko do slej zbranih podatkov smo flančišča kot toponime odkrili na Drnovem, Bregah, Vihrah in na Gorenjih Skopicah.

$\mathrm{Na}$ Drnovem je bilo Flančišče mikrotoponim za rodoviten prostor $\mathrm{v}$ sklopu ledine, ki jo opredeljuje toponim Trebež in njene soseščine, znotraj več hektarjev velikega osrednjega vaškega pašnika Barovna.

Tu so imele ženske flančišča, vsaka eno gredo po $5 \times 5 \mathrm{~m} .{ }^{\mathrm{I2}}$ Vsak je imel eno gredo, kot soba veliko, tam so si posejale flance, pa peso, po tem pa so tisto pukale in presajale po njivah. ${ }^{\mathrm{I3}}$

Io Iz nem. Pflanze, kot rastlina ali narečno flanc. V obravnavanih vaseh je flanc sinonim za sadiko zelja.

Informator VMA, TTR.

I2 Informator RVA

13 Informator RVA
Na Bregah je toponim Flančišče sčasoma zaobjel prostorsko nekaj hektarjev velik nekdanji pašnik na meji z drnovsko Barovno. Na robovih in v notranjsoti tega pašnika so izpričana flančišča tako na Bregah (Sl. 2), kakor na Drnovem. ${ }^{14} \mathrm{Na}$ meji med Barnopakami in Flančišči so v daljšem pasu izpričani majhni vrtovi za sajenje pese in zelja za kasnejši razsad, ${ }^{15}$ kar prav tako ustreza flančiščem.

Iz Gorenjih Skopic je znan naslednji opis:

Flančišče. Spomin mi seže v pretekla leta,
nazaj v mojo mladost, ko si je naša mama v
zgodnji spomladi, kot so včasih rekli - ko se
ptički ženijo, naložila samokolnico dobrega
gnoja in ga peljala po makadamski cesti do
konca vasi, in še ven. Tam smo kraj imenova-
li Flančišce. Bilo je v grmovju. Rasel je črni
trn. Tam je imela vsaka hiša gredico, da so si
spomladi posejali flance za zelje. Trnje okoli
je z vinkom obsekala, zemljo prelopatala in
zagnojila. V velikem tednu, na veliki petek,
je vzela seme, ki si ga je sama vzgojila, vzela
grablje in šla posejat seme. Ko pa je prišlo ob-
dobje za sejanje, je gospodar vzel koš in šel
populiti flance in jih prinesel na zelnik, kjer
smo flance posadili z lesenimi klini. Po tem
smo pazili, da njiva ni ozelenela. Če je še bilo
vreme naklonjeno, je bilo zelja, da smo na-
polnili polno vinsko kad. Bilo ga je za celo
leto. (Vodopivec zoo8, p. 30 ).

Gorenjeskopiško Flančišče je kasneje, po razdelitvi skupnih površin, zajemalo »27 parcelic, velikostipo 2-3are. $\ll^{16}$

Flančišče torej ( $v$ današnjem smislu) posnema domačo rodovitno in gnojeno vrtno gredico, vendar na dislociranem koščku zemljišča, navadno znotraj večjega pašnika, kjer se vsako leto išče in izkorišča spočite in rodovitne predele, $\mathrm{ki}$ so nastajali z grmovno preperlino v povrhnjici. Bistvena prednost tako odbranih površin je njihova rodovitnost, ne da bi jih bilo potrebno gnojiti z domačim gnojem, ki ga je vselej primanjko-

I 4 Informator VMA, FSI, VER, RVA

I5 Informator VER

I6 Informator XSX-MST 
valo. Varstvo rastlin pred živalmi, predvsem pred pašno živino, je zagotavljala okoliščina krčenja za flančǐ̌če v grmovju. Za tako ograjena flančišča vemo iz Drnovega in z Breg. Kaže, da o njihovem značaju in razprostranjenosti govorijo tudi imena sama, v odnosu do površine, znotraj katere velja toponim. Na Bregah je več hektarjev velik predel pašnika med ljudmi enotno poimenovan Flančišči, torej Flančišča. To je moč razložiti $s$ tem, o čemer priča že samo izročilo in pričevanja, in sicer, da so bila na tem območju flančišč razkroplejena po različnih predelih celotnega območja, pa tudi na robovih. Na Drnovem so flančišča obstajala na starem, več hektarjev velikem pašniku ledine Barovna, znotraj katerega je bila izkrčena ledina Trebeži, znotraj te pa velja toponim Flančišče. Vendar je bil ta prostor dovolj velik, da je po potrebi omogočal menjavanje gredic. Primer iz G. Skopic že kaže primer, kako so starejša migrirajoča flančišča prerasla $v$ stalne gredice, ki so jih v 1930-tih gnojili, kar je povezano z že razparceliranimi deleži nekdanjega skupnega pašnika.

Bistven poudarek opisanih flančišč je torej $\mathrm{v}$ njihovi legi, in sicer na rodovitnem in vlažnem območju spodnjega polja ter njihovi vlogi v procesu pridelave zelja, ki je tu, kakor tudi marsikje drugod, pomenilo steber prehrane predvsem hladnega dela leta.

Na flančiščih pridelane sadike so po razsaditvi zahtevale nadalnjo nego na primerno pripravljenih in kvalitetnih zemljiščih. S tem že prehajamo na drugo obliko rodovitnih zemljišč, ki so se prav tako nahajale v spodnjem polju, kamor so običajno v kolobarju za junijsko žetvijo žita, na strnišče prenseli sadike - flance. To so njive zelniki oz. njive s (po)vrtninami. Takšne njive imajo tod značilna imena Zevniki, Drage, Drašce ali Vrti. ${ }^{17}$ Sledi izbran primer ledine Zev-

Tu omenimo, da toponimi Zevniki in Flančišče - obstajajo tudi v zgornjem polju (npr. Vihre in Drnovo), kjer so izvajali iste dejavnosti, kot v spodnjem polju. Vendar retrogradni pregled razvoja zemljiških deležev kmetij, ki so tam nekdaj obdelovala zemljišče, pokaže, da gre glede na ostale kmetije v vasi, za izrazito mlade ali vsaj relativno mlajše kmetije. Zanje, v času njihovega formiranja, v spodnjem polju ni bilo več prostora za pridobitev zemljiških deležev. Prav te kmetije si zato (čeprav redkeje), po vzoru iz spodnjega polja, urejajo zelnike/flančišča $v$ izbranih in najrodovitnejših predelih zgornjega polja. Npr. na Drnovem ima relativno najmlajši vaški pre- niki na Drnovem, kot najtipičnejše oblike njive s (po)vrtninami na obravnavanem območju, kjer so pridelovali zelje v stopnji po razsadu iz Flančišč. Poglejmo.

\section{Zelniki, Zeuniki}

Med najtipičnejše njive s povrtninami na Drnovem sodi ledina Zevniki na prvi savski terasi pod vasjo. O tamkajšnji izjemni rodovitnosti priča izročilo o pridelovanju zelja, ki ga danes nekateri imenujejo staro zelje ${ }^{\mathrm{r8}}$ in pričevanja o posebnem tretiranju teh njiv (Rihter 2015, 25). Količino pridelanih zeljnih glav s teh njiv so merili v številu vozov oz. v konicah. Omenjajo se več sto litrske kadi kisanega zelja ter prav tako tudi prodaja svežih zeljnih glav v bližnjem hribovju, npr. v smeri Rake in drugih delov Krškega hribovja. ${ }^{19}$ Pričevanja o velikem pomenu zeljnega pridelka na Drnovem (npr. Počkar 1998, 287) ter o visoki stopnji znanja in dovršene ter obsežne pridelave zelja, govori podatek iz leta 1862 , ki sicer nekoliko vzneseno pravi, da naj bi v drnovskem »hafnu«, tj. na današnji ledini Zevniki, pridelali dovolj zelja za vso Ljubljano (Rihter 2015, 25 ). Razširjeno in uspešno pridelavo zelja na Drnovem omenja tudi kronika sosednje župnije Videm ob Savi, iz leta ı880, ki govori, da na Vidmu zeljnih sadik niso vzgajali sami, temveč so jih kupovali v vasi Drnovo, v leskovški župniji na Kranjskem, po 30 do 50 krajcarjev za Ioo kosov (Ripšl 2007, 154).Zevnikom po kvaliteti primerljiva ledina za pridelavo zelja in drugih povrtnin je bila na nasprotnem bregu stare struge, na ledini Breg, prostor med njima je nosil zgovorno ime - Med vrti. Na Bregah so tem istim namenom, za razsad sadik služile ledine Vrti, Barnopake in Drage. V vseh primerih je razvidna Ioo do naj-

del im. Pasje polje, svojo ledino Zevnik, južno od vasi v zgornjem polju. Enako najdemo južno od vasi ledino Flančišče v vasi Vihre. Poglavitno jedro površin za flančišča in zelnike je tod nedvomno vezano na spodnje polje.

I8 Tako so pravili neki vrsti zelja z odličnimi lastnosti tako za solate kakor tudi za kisanje. Imelo naj bi drugačne lastnosti od t. i. Ljubljanskega zelja (Rihter 2015,25) in ni enako t. i. varaždinskemu zelju. Ta vrsta zelja je po mojem poznavanju ohranjena le še na nekaterih drnovskih kmetijah, seme pa je vsaj v enem primeru preživelo celo nemško okupacijo, saj so ga izgnanci v času internacije v Nemčijo vzeli sabo in je bilo po vrnitvi v uporabi še naprej.

19 Informator TTR, STM, MIM, idr. 
več 200-metrska oddaljenost od vasi. Takšne njive so bile deležne tudi izdatnejšega gnojenja in nasploh večje pozornosti.

Tako so na Drnovem usedline iz vaške Kilarjeve ali Jakšave mlake uporabljali prav za gnojenje dveh za pridelavo vrtnin najpomembnejših ledin Zevniki in Breg (Rihter 2014, 39).

Iz zelnikov v spodnjem polju se sedaj prestavimo v vasi, na stare savske ježe, oz. na vaška dvorišča, kjer se dvojnost življenja na meji obeh svetov pokaže, tokrat $\mathrm{v}$ še manjši obliki kot pri ravnokar opisanih flančiščih in zelnikih, to je v t. i. zgodnjih in poznih gredah ali vrtih. Tudi ti so bili plod naravnih danosti in izbrane lege naselbin ter mikrotopografije posameznih dvorišč.

\section{Zgodnje in pozne grede/vrtovi}

Vpogled v mikrotopografijo planiranja posevkov na meji obeh ekoloških con, nam dajejo tudi pričevanja o hišnih vrtovih v vasi Brege, kjer se naselbinski deli severne polovice vasi deloma usedajo na pleistocensko teraso/zgornje polje, s spodnjimi deli dvorišč pa proti severu že prehajajo $\mathrm{v}$ poplavno ravnico/spodnje polje, značilno imenovano Vrti (Sl. 2). Vrtovi, kot deli spodnjih koncev dvorišč, so bili ograjeni s pletenimi plotovi iz vejevja, v katerih so bili značilni prehodi im. prelozi. Severna polovica vasi Brege, torej ta, ki je neposredno mejila na spodnje polje, je imela vrtove na senčni in vlažnejši, prvi spodnji terasi (Sl. 2). Južna polovica vasi, onkraj vaške ceste, pa je že v celoti stala na sončnejši, pleistocenski terasi, a s prepustnejšo, prodnato prstjo. Bistvo razlike $\mathrm{v}$ legi obeh vrtov strne informator $\mathrm{z}$ severnega dela vasi: »V južni polovici vasi je imel vsak svojo gredico skonca dvorišča, tam je bilo prej za saditi spomladi. Ti so imeli vse poprej, mi pa vse kasneje. Njim pa je ob suši vse prej vzelo kot nam. $\ll^{20}$ Po tem principu so torej tod ravnali tudi pri vseh drugih kulturah na večjih njivskih površinah. ${ }^{2 I}$ $\mathrm{V}$ 20. stoletju vsakdo seveda te možnosti ni imel. Mnoge po nastanku mlajše kmetije namreč niso imele deležev v spodnjem rodovitnejšem polju (prim. Rihter 2015, 34-52 in Sl. 16). Princip »po-

\footnotetext{
20 Informator VER

2I Informator VER, TTR, RAD, FSI, idr.
}

znega vrta« (prim. Počkar 1998, 58-60) oziroma njiv, ki so vzdržale sušo ter tako zagotavljale pridelek, je bil tu tesno povezan s poplavno ravnico. Resen strah pred sušo, ki se najsiloviteje in hitro pokaže predvsem na zgornjem, peščenem polju (prim. Teppey I97I, 22) slikovito opiše naslednji stavek, ki se nanaša na zgornje polje: »Pri nas je namreč samo takrat dobra letina, ako naše brate preko Sotle zaliva voda, to se pravi: Ako poleti ali vsaj v času glavne rasti dvakrat ali trikrat na teden dežuje. « (D. S. I930, II).

O pripravnosti aluvialnih tal za intenzivne gojitvene potrebe na tem področju prvič slišimo v letu I893 ko so ob Savi pri D. Skopicah želeli postaviti deželno trsnico - po napadu trtne uši ki bi proizvedla 0,5 mio cepljenih ameriških trt letno. ${ }^{22}$ Po drugi svetovni vojni je trsnica pričela delovati, in sicer na ledini Marof. ${ }^{23} \mathrm{Na}$ tem mestu zgolj omenimo kmetijsko in gospodarsko intenziviranje poplavne ravnice, ki je sledilo v prvih dveh desetletjih po koncu 2. svetovne vojne in ki je vzpostavilo obsežne monokulturne nasade topolov in njiv s krmnini in semenskimi rastlinami na obeh bregovih reke save med Krškim in Brežicami.

Prisotnost ali bolje rečeno neposredna bližina mokrega sveta je bila za preživetje v ravnici ključnega pomena. Poglejmo sedaj pobliže različne vidike življenja z mokrim svetom.

\section{Mokri svet Vrbine}

Mnogo najnižjih predelov poplavne ravnice so $\mathrm{v}$ I9. stoletju uporabljali kot pašnike (Rihter 20Io, 34). Pašniki so tod ob izteku fevdalne dobe zajemali nekaj sto hektarjev različnih kakovostnih razredov. Med njimi so bile tudi mrtvice in območja s talno vodo na površju. ${ }^{24}$ Skupnih pašnikov (kot katastrsko vodene kulture) na zgornjem polju v k. o. Drnovo, razen redkih izjem tedaj

\footnotetext{
22 Dolenjske novice (1.5. 1893).

23 Informator ZXF.

24 Glej franciscejski kataster za k. o. Drnovo - grafični del (mapni list VI), abecedni seznam posestnikov, zapisnik zemljiških parcel in cenilni elaborat; za k. o. Krška vas - zapisnik zemljiških parcel, abecedni seznam posestnikov in in cenilni elaborat ter za k. o. Leskovec pri Krškem - grafični del (mapni list VII), abecedni seznam posestnikov, zapisnik zemljiških parcel in in cenilni elaborat (gl. Literatura).
} 
skorajda ni bilo (Rihter 2015, 37). Sredi prve polovice 20. stoletja so bile največje pašne površine, še vedno omejene na poplavno ravnico. Med njimi so bile ponekod še vedno odprte vodne površine $s$ talno vodo in tudi mrtvice. Različne oblike vodnih površin so pestrile okolico, $v$ okviru paše pa so bile pomembne predvsem zaradi napajanja živine (Vodopivec 2008, p. 72).

Do leta 194I je obstajala učinkovita izraba mokrega sveta tam, kjer so bile vodne površine še prisotne. Glede na oddaljenost od naselbinskih delov je šlo po naši presoji (s kriterijem možnosti za koriščenje) za 4 skupine vodovja, ponekod brez izrazitih meja pri prehodu iz ene oblike v drugo:

I. vodne površine $\mathrm{v}$ neposredni bližini vasi ali znotraj njenega obsega (vaške mlake, talna voda),

2. vodovje znotraj obsega vaškega polja ali na njegovem obrobju (talna voda, stalni (potok) in občasni izviri),

3. voda v oddaljenih pašnikih Vrbine (mrtvice) in

4. glavni tok Save (tekoča voda).

$\mathrm{V}$ vseh naštetih conah so se odvijale različne oblike paše in številne druge dejavnosti, ki jih predstavljamo v nadaljevanju.

\section{Mokro godenje lanu}

Mokro godenje lanu v mrtvici je bilo v obravnavanih vaseh do slej izpričano le na G. Skopicah na ledini Spina, kjer so to opravilo dokumentirano izvajali še v 1930-tih letih. Povsod drugod so v tem času izvajali le še vlažno godenje lanu na travnikih ali njivah v nesposredni bližini vasi. To povezujemo $\mathrm{z}$ dejstvom, da so mrtvice $\mathrm{v}$ večjem številu tedaj obstajale le še na skopiškem. Danost so $s$ pridom izkoriščali, seveda premišljeno do drugih odprtih vodnih virov, v katerih so napajali živino ali prali tkanine. Znano je namreč, da namakanje lanu poleg smradu, povzroča tudi toksikacijo vodnih virov (prim. Hoffmann 1996 , 645; 2008, 48). Tozadevno je pomembno, da je na Spini, poleg ene večje vodne površine, obsta- jalo še nekaj manjših, nepovezanih vodnih površin ob poti na Gorenje prude:

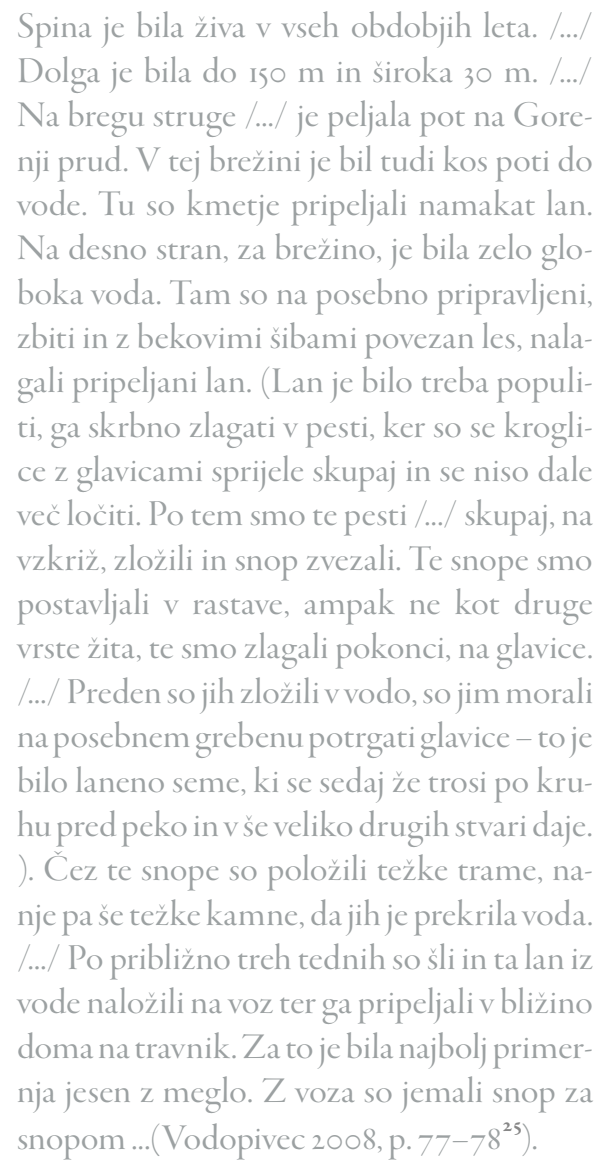

$\mathrm{S}$ posevki lanu in konoplje so praviloma $\mathrm{v}$ vseh vaseh povezane tudi skoraj izključno njive v poplavni ravnici.

\section{Ribolov}

$\mathrm{O}$ t. i. športnem ribolovu v času pred 1945 na območju naše obravnave, ne poročajo nikjer. Savski ribolov je bil v drugi četrtini 20. stoletja tod predmet zakupa, z njim pa so se ukvarjali različni posamezniki. $V$ obravnavanih vaseh so to bili brodniki in tisti z malo ali nič zemljišč, vendar ne množično. Iz vasi bližje regulirani Savi (Brege in Mrtvice) je poimensko znanih nekaj ribičev, ki so lovili ribe za blagovno menjavo. Navkljub temu je bilo na individualni ravni posameznih

25 Neobjavljeno delo (gl. Literatura). Navedeni odstavek je bil objavljen pri Rihter (2010, 25-26). 
kmetij obvladovanje številnih ribolovnih veščin zabeleženo marsikje.

Poglejmo sedaj ugotovitve o stanju voda in zmožnostih za ribolov $\mathrm{v}$ vaseh od zahoda proti vzhodu. Na Drnovskem spodnjem polju zaradi nestanovitne narave zastalega vodovja (nihanje talne vode) in drugih dejavnikov (tacanje živine in prisotnost domače perjadi) stalno prisotnih rib v 20. stoletju ni bilo nikjer. $\mathrm{Na}$ območju Breg smo glede na število mest $s$ stoječo ali zastalo vodo (npr. Velike vode, Globajnk ali Zlatičje), pričakovali, da bomo tam našli pričevanja o prisotnosti rib in njih ribolovu (Rihter 20IO, 3I), sedaj pa je na podlagi dodatnih pričevanj že jasno, da tu v tridesetih letih preteklega stoletja ni bilo rib, razen krajša ali daljša obdobja za poplavami, kjer je šlo za naplavljene ribe, ki so jih za hrano seveda pobirali iz kotanj. ${ }^{26} \mathrm{Tu}$ kajšnji manjši obseg talnega/zastalega vodovja in s tem povezani nestanovitni življenjski pogoji, so onemogočali preživetje in reprodukcijo ob povodnji naplavljenih rib. Vsa pričevanja o ribolovu na brižanskem, so torej že vezana izključno na glavni savski tok. To je razvidno tudi po izpričanih ribolovnih vrstah v vasi Brege: somi, veliko belic velikosti do $30 \mathrm{~cm}$ in občasno sulci (Rihter 20IO, 3I). Nasprotno pa na Vihrah, v t. i. vihranski vrbini, kjer so bile mrtvice tedaj še ohranjene (npr. na ledini Struga/Spina), še zlasti pa na več mestih na območju obojih Skopic, v t. i. skopiški vrbini, je bil pravi ribolov v mrtvicah še zelo razširjen. O vodnatosti in življenjskih pogojih tamkajšnjih mrtvic pričajo omembe ribjih vrst in temu prilagojena ribiška oprema, kakor bomo videli v nadaljevanju. Poglejmo sedaj natančneje pričevanja o ribolovu v posameznih vaseh, od tistih z bolj osušenimi mrtvicami, kjer so ribolov izvajali le še neposredno ob reki (Brege), do tistih, ki so v okviru svojega polja še imeli mrtvice (Vihre, G. in D. Skopice).

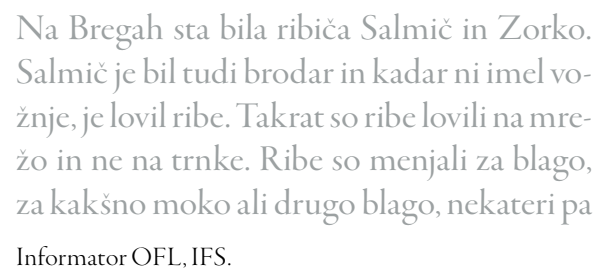

\section{so jih že prodajali, npr. Salmič. Ribič Zor- ko si je sam pletel ribiške mreže. Lovili so na križ. Dobili so mrene in ploske, včasih tudi kakšnega soma. Največ je bilo ploskov. ${ }^{27}$ Zorko je lovil tudi s sakom, največ je bilo ploskov, ki pa so vsi po nafti smrdeli. ${ }^{28}$ V̌́a- sih so lovili tudi menke. ${ }^{29}$}

$\mathrm{Z}$ ribolovom so se na Bregah pred drugo svetovno vojno ukvarjali poleg Zorka, še Kočevar in Judež.

\section{Ker so bili tabarharji so si na ta način služili kruh. Mama so od njih kupili ali menjali ribe za moko. Bile so to ribe velikosti do $20 \mathrm{~cm}$ in so imele veliko kosti. ${ }^{30}$}

$\mathrm{V}$ vas je pripeljal žive $\mathrm{v}$ posodi napolnjeni z vodo. ${ }^{3 \mathrm{I}} \mathrm{Na}$ Drnovem, pravijo, da so bile savske ribe malokdaj $25 \mathrm{~cm}$ velike, z njimi pa jih je zalagal stari ribič Zorko, im. tudi Zorkac z Breg, ${ }^{32} \mathrm{ki}$ je lovil z mrežo. ${ }^{33}$ Brižani so pobirali/lovili naplavljene ribe v starih strugah tudi po poplavah.

Podobno je bil ribolov v vasi Mrtvice priložnostno vezan na predele $\mathrm{v}$ starih strugah, sicer pa ob glavnem toku:

\section{V kakšnih globanjkih ali tolmunčkih so lo- vili, kjer je ostalo kaj rib. Šularu Martenk je imel tudi nekakšne hakle, pa šivanko lese- $\mathrm{no}^{34}$ (prim. Sl. 3).} $\downarrow$

(a)

(

Pletenja mrež so se pri nejm učili še v povojnem času. ${ }^{35}$ Sicer pa je bil omenjeni mož tudi eden izmed brodarjev na brižansko-mrtviškem brodu, ki je v Vrbini, najverjetneje v bližini broda, po pričevanju živel v nekakšni zemljanki. ${ }^{36}$ Splošno znan pa je bil tudi kot ribič. Pri brodu je bila kasneje tudi brodarska hišica.

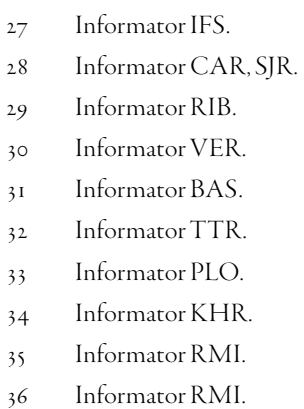


V Vihranski vrbini je bil, za razliko od do slej omenjenih področij, že možen ribolov v mrtvici celo še nekaj časa po 2. svetovni vojni:

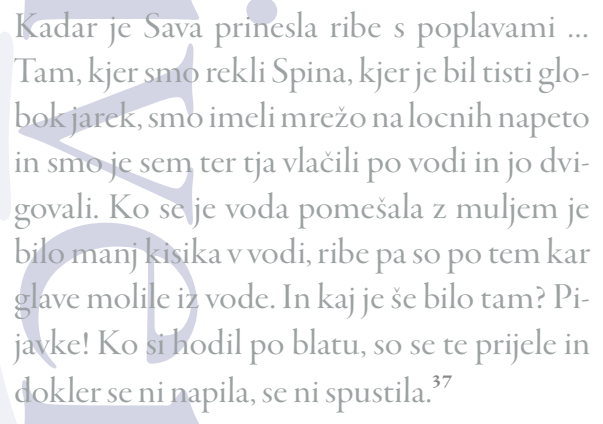

Ribolovni tereni na skopiškem so bili za razliko od omenjenih vasi mnogo bolj pestri. Ribolov je bil mogoč na številnih mestih, tako ob Savi, kakor tudi v mrtvicah, npr. na predelu Spina in Amerika, predvsem pa na ledinah vzhodno od predela Studenec. To območje se je polnilo s tamkaj (na Studencu) izvirajočo vodo, ki je v obliki potočka odtekala po opuščenih savskih strugah severno od ledine Patarsko, Lastine in Gladiš, in sicer preko ledin: Perišče, Dolenji prud, Marlenček in Šlegel (Mali/Veliki), ${ }^{38}$ kjer se je izlival v Savo (Rihter 20IO, 27 in 3I). Morfologija starih savskih strug na njegovi poti je narekovala ustvarjanje blatnih tolmunov in plitvih prehodov s tekočo vodo. Za prve poročajo o izobilju rib in pijavk, na drugih pa so bili zaradi plitvin ustvarjeni prehodi, ki so vodili v notranjost Vrbine, $\mathrm{k}$ reki. Prehode za pešce so kazali na dnu položeni večji kamni. Kot taki pa so bili priročni za pranje tkanin (stepanje), kar so tu dokumentirano tudi izvajali (gl. Pranje...). Potoček je presahnil pred več kot pol stoletja, vendar po večjih povodnjih, ko se za kratek čas poustvarijo (v oziru vodostaja v zaledju ravnice) nekdanjim podobne razmere, se na ledini Studenec ponovno vzpostavi izvir, ki po okoli 3 tednih presahne, npr. povodenj 2010 in 2012. Voda priteka (brizga) pod pritiskom navpično iz dna struge, navadno iz ene večje luknje (globina $120 \mathrm{~cm}$, širina $0,5 \mathrm{~m}$ ), ki se pri tem oblikuje ter iz nekaj manjših v neposre-

37 Informator PAT.

38 Informator RCD dni bližini ${ }^{39}$. Prav takšno stanje pa opisujejo tudi ljudski spomini na Drnovem, ob pričetku zalivanja stare struge pod vasjo (Gl. Lomljenje ...).

$\mathrm{Na}$ ledinah vzhodno od Studenca so lovili krape in šlaje (linj; Tinca tinca) tako, da so mreže vlekli k sebi.

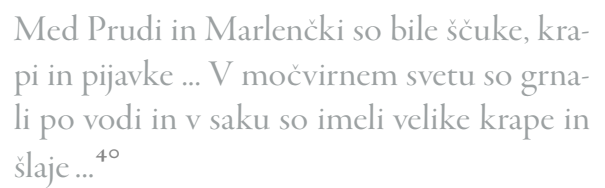

$\mathrm{Na}$ ta način so dobili po okoli 5 do 6 rib. $^{4}$ Voda je bila tu blatna in gosto poraščena, ob njej so pasli kobile, ki jim je voda tedaj segala do vampa in kadar so prišle ven, so jim morali z nog pobirati in stiskati pijavke ${ }^{42}$ (gl. tudi Rihter (2010, 3I). Studenc - tu je voda tekla, notri so bile ribe, /.../ stric je lovil ribe na Perišču ${ }^{43}$. V bližnji Borovini se je predel imenoval Žokalova amerika, kjer je bila stalna voda. Pred 80 leti so se nekateri tam kopali, drugi pa lovili ribe. ${ }^{44}$ Dolenjeskopiški pastirji so ribe lovili v kotanji Veliki šlegel ob ob Savi pri pašniku Spinca. V toplih dneh so navadno slekli del oblačila, jih na odprtih koncih zvezali s srebotino ter jih uporabljali za lovljenje in prenos rib. Ribe so čistili ob glavnem toku Save v čisti vodi, pekli pa na ognjišču iz blata. ${ }^{45}$

O življenjskem okolju šlajev na območju Studenca in Perišča v tridesetih letih preteklega stoletja piše Uršula Vodopivec:

Ta vrsta rib se zadržuje v vodi z resjem. Njih loviti na že omenjeni način zaradi resja ni mogoče. Oče si je plel takšne, imenoval jih je bobne, koše so rekli nekateri. Spravil si jih je v Vrbini, pod noč pa jih je šel nastavit. Potlačil jih je med reso, navlekel nanje tisto dolgo travo in odšel domov. Zgodaj zjutraj je že moral iti pogledat, če je kateri (šlaj, op. J. R.

39 Stanje dokumentiral avtor prispevka 3. 10. 2010, 27. 10. 2010 in 8. I I. 2012.

40 Informator RCD

4I Informator RCD

42 Informator RCD

43 Informator SZP.

44 Informator RCD

45 Informator $\mathrm{ZHK}$ 


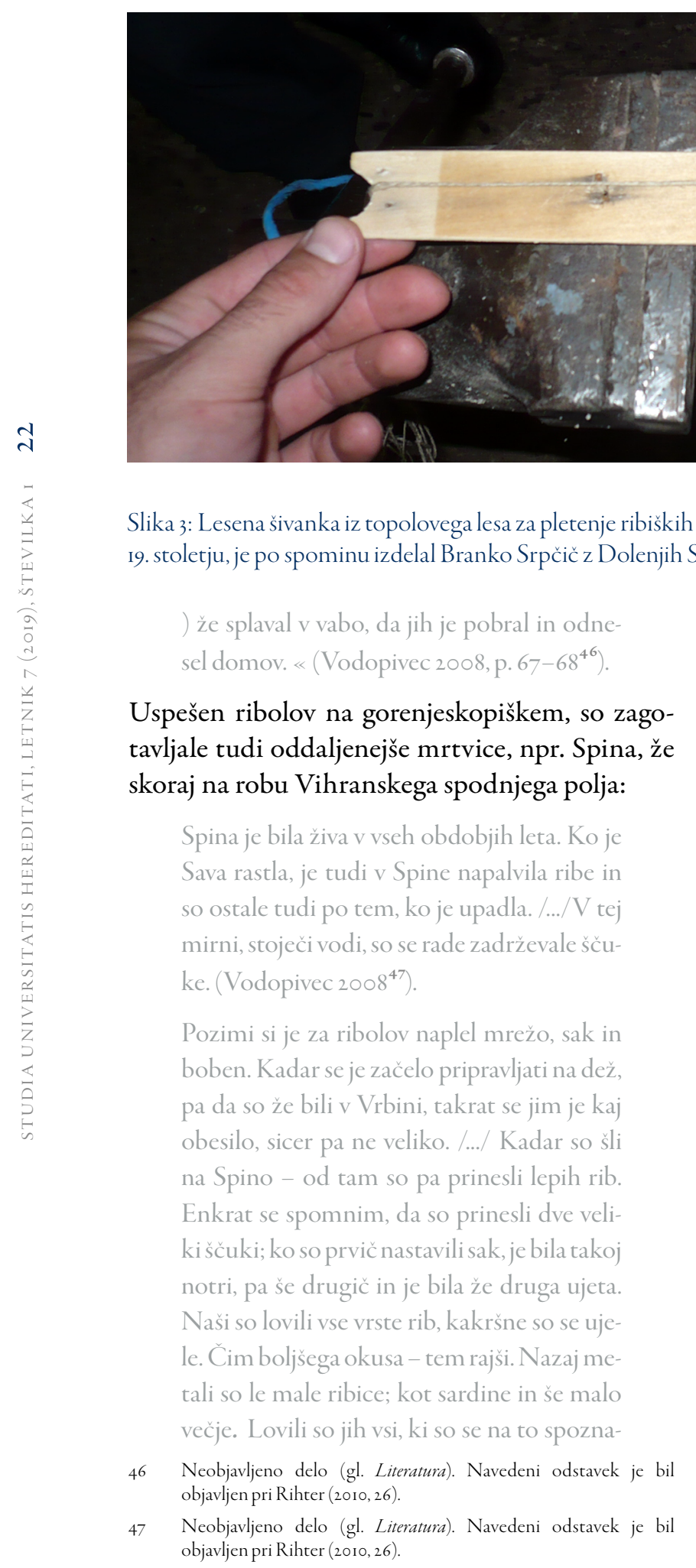

li in če so imeli s kom. (Vodopivec 2008, p. $67-69){ }^{48}$

Torbi v kateri so na skopiškem nosili ribe domov, so pravili karnir, ki je bil sešit iz domačega platna (Vodopivec 2008, p. 67-68). V bližini je bila tudi mrtvica Zlatič, ki je bila sicer znana, kot lokacija za zdravljenje s pijavkami, izpričana pa je tudi kot ribolovno območje. ${ }^{49}$

Pomudimo se še nekoliko na tem območju $\mathrm{s}$ stališča modernih opažanj in se $\mathrm{v}$ naslednjem odstavku ponovno vrnimo $\mathrm{k}$ ribolovu. $\mathrm{Na}$ njivah, ki so do danes nastale v strugi Spina, se v ornici občasno vidijo ostanki lupin rečnih školjk (Unio sp. ). Struga Spina predstavlja ostanek zadnje aktivne struge t. i. skopiškega rokava ${ }^{5 \circ}$ pred rečno regulacijo v 19. stoletju (Rihter 2009; 2015, 6I-69; 2016a, 58; 2016b, I5I). Opažanje se sklada z situacijo, ki je bila vidna leta $2016-2017 \mathrm{v}$ tej isti strugi, nekaj sto metrov severozahodneje od Spine, kjer je ob izgradni jezu za HE Brežice prišlo do uničenja Petrove škarpe ob njenem izklinu v Skopiški zaliv, v dolžini $300 \mathrm{~m}$. Pod uničeno su-

48 Neobjavljeno delo (gl. Literatura). Navedeni odstavek je bil objavljen pri Rihter (2010, 25).

Informator TXJ.

so Savski tok najjužnejšega dela skopiškega rokava je pred savsko regulacijo zajemal ledine Gorenji prudi - Spina (G. Skopice) - Zlatič - Srednji prudi - Studenec - Perišče - Dolenji prudi/Marlenčki Spinca - Veliki/Mali Šlegel. 
hozidno krono nasipa Petrove škarpe, ki je prečno zapiral vhod v skopiški rokav, so bili na globini do $3 \mathrm{~m}$ vidni tako ostanki lukenj in lesenih pilotov - ostankov regulacijskih del (prim. Rihter 2016a, 58; 2016b), kakor tudi zamuljene leče nekdanjih rečnih nivojev dna z izdatnimi količinami lupin rečnih školjk.

Nadaljujemo s pričevanji o ribolovu. Tudi druga poročila s Skopiškega potrjujejo zgoraj izpostavljene lokacije in vrste rib: Na Skopiškem se je lovilo s saki in kadar je voda rasla se je grnalo po vodi. Skopičani so večinoma lovili ob glavnem toku na ledini Pod krči ali do Cesarskega (D. in G. cesarsko), kamor je sodil tudi rečni zaliv im. Skopiški zaliv. Lovili so klece (tj. pisanica), zelenke (tj. zelenike), žagarčke (t. s. ostriži), šlaje (tj. linje) idr. ${ }^{\text {II }}$ (gl. tudi Rihter 2oro, 32). Uršula Vodopivec opisuje Skopiški zaliv, kot nekakšen zaton, ki se je običajno uporabljal za pranje pšenice. To mesto drugi opisujejo kot jamo v Savi, z imenom Perina jama. ${ }^{52}$ Kadar so na tem mestu ob spiranju žita nastavljali tudi sake, so ribe privabljali s trosenjem žita v vodo (gl. Perišča). Nadalje pravi tudi, da so nekateri ribe dvigovali iz vode s pomočjo koze. Ta pa je sestavni element ribolova z mrežo po metodi, tod imenovani na križ. O tej isti metodi ribolova govori tudi pričevanje: Mreže so pletli sami ali pa so jih od kje dobili. Lovili so v Savi šstangami in locni, pa so dvigovali.

\section{Pranje thanin in žit}

Vasi so imele po regulaciji Save različno dolgo pot do reke Save. V tridesetih letih preteklega stoletja v vaseh zahodno od Viher žehte praviloma niso več prali na Savi. V vaseh tedaj ni manjkalo vaških štirn, pa tudi privatne so bile vse bolj pogoste. ${ }^{54}$ Predvsem so na Savi še vedno spirali snetljivo žito in to opravilo je za sabo potegnilo tudi pranje rjuh. Konopljene ali lanene spalne rjuhe so imele ravno pri tem opravilu ključno vlogo oz. so bile sestavni del tega opravila. Pred

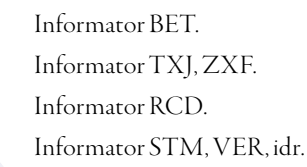

dejanskim pranjem so jih namreč najprej izkoristili še za grobo sušenje spranega žita na prodišču, nakar so bile končno oprane tudi same. Gljivam žitnih sneti, so se ob dozorevanju spore spremenijale $v$ temen prah, kar je imelo za posledico temno obarvanost oziroma zaprašenost tudi sicer zdravih žitnih zrn. Takšno žito je zavrnil vsak mlinar, zato so bili viri tekoče in čiste vode takorekoč nujni. ${ }^{55}$ Čeravno v dobi številnih vaških štirn, smo spomine, še večkrat pa prvoosebna pričevanja o tem opravilu zabeležili pri domala vsaki hiši/informatorju.

V tem oziru je na Gorenjih Skopicah veljala nekoliko drugačna situacija, saj se je v eni od vasi najbližjih starih savskih strug, preko ledine Perišče, pretakala tekoča voda - studenčnica, ki je izvirala na ledini Studenec (gl. Ribolov). To danost so zaradi razmeroma majhne razdalje od vasi (ca. $700 \mathrm{~m}$ ), napram tisti do Save, s pridom izkoriščali. Voz s tkaninami so pripeljali na Perišče, kjer so perice stale v vodi in stepale rjuhe.

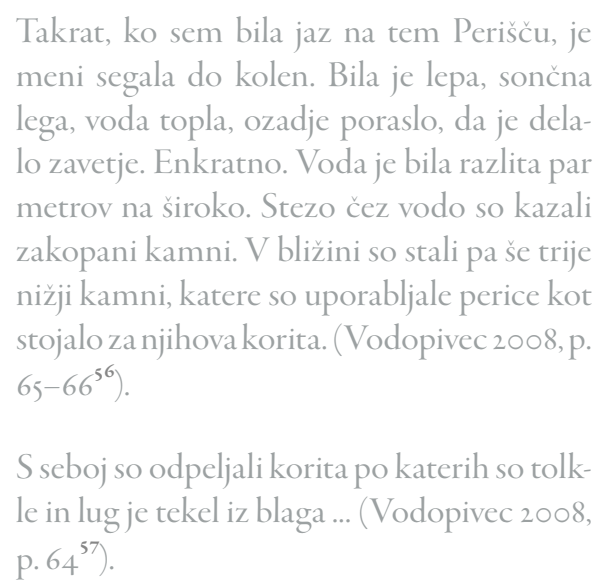

Na območju Perišča je bila voda prisotna voda še v $1960-$ tih. $^{58}$

Drugo lokacija za pranje perila na Gorenjeskopiškem se nanaša na glavni savski tok, kot stranska dejavnost ob spiranju snetljivega žita.

\footnotetext{
55 Informator VER.

56 Neobjavljeno delo (gl. Literatura). Navedeni odstavek je bil objavljen pri Rihter (2010,26).

57 Neobjavljeno delo (gl. Literatura). Navedeni odstavek je bil objavljen pri Rihter (2010,26).

58 Informator ZXF.
} 
Slednje opravilo je zahtevalo večje količine tekoče vode. V Gorenjeskopiški vrbini, na ledini Gorenje cesarsko, v bližini Skopiškega zaliva, sta bili v brežino vsekani dve dostopni rampi do vode (gl. Gradbeni...):

Oče je pripeljal voz s konicami do praga, tu
so naložili čeber z žehto. Mama je nanosila
v drug čeber še tedensko perilo, v tretjega so
pa nanosili še snetljivo pšenico, da jo je op-
rala v Savi. Ko je mama prala, sta oče in brat
obrnila seno, jaz pa sem na naši obali (bili so
lastniki travnika nad reko, op.J. R.) pazila se-
stri. Brat in oče sta navezala na travniku štrik,
da sva midva z bratom obešala rjuhe in po-
tem še ostalo perilo /.../ Midve z mamo sva
zlagali rjuhe in perilo, ter jih pospravili v čeb-
re, odvezale štrike, pospravile grablje. Moški
so pa oprali in skrtačili v vodi konja in kravi
ter jih napojili. No, oče pa je moral še pogle-
dati v sak, če se je kaj slučajno zataknilo in je
treba rešiti. Tako smo preživeli dan in se vsi
oprani in okopani vrnili domov. (Vodopivec
2008, p. 65 - $66^{59}$ ).

Nekaj deset metrov gorvodno od ravnokar opisanega mesta, so v zatonu, po Uršuli Vodopivec (ustno) imeli plavalci 6 stopnic za skakanje $\mathrm{v}$ vodo. To mesto oz. zaton, ki ga omenja, je po drugih virih prostor, ki so ga imenovali Perina jama na Savi (gl. Ribolov), drugod imenovan skopiški zaliv. V lokalni zavesti gre tu za eno najpomembnejših mest na toku Save med Krškim in Brežicami. Ta prostor je vsaj v i9. stoletju, najmočneje zaznamoval stik t. i. krškega prekopa $\mathrm{z}$ skopiškim rokavom, ki je do tlej narekoval različne zgodovinske meje (Rihter 2009; 2015, 6I-69; 2016a, 58; 2016b, I5I).

Na Mrtvicah so v i9. stoletju še prali tkanine severno od ledine Stare vačke, v strugi, ki so jo imenovali Prudi. To je bilo pred nami, kar so starši povedali. ${ }^{60}$ Brižani so prali pšenico, nekateri tudi perilo, na Sopin, na Sopini (im. tudi Sprud ali $\operatorname{Prud}^{6 r}$ ), kjer je deloval brižanski/

59 Neobjavljeno delo (gl. Literatura). Navedeni odstavek je bil objavljen pri Rihter (2010, 26).

60 Informator KHR.

6I Informatorja DIN, DIT, idr. mrtviški brod in kjer je bilo rečno dno drobnoprodnato. Tu so tudi napajali živino. Vsa ta opravila so opravljali na istem mestu, kajti drugod v brižansko-mrtviški vrbini, so bili bregovi že strmi, ker so Savo gradili savski delavci. ${ }^{62}$ Drobnoprodnato rečno dno in plitvino povsod navajajo kot temeljni pogoj za izvajanje teh del. Tudi na Vihrah so prali pšenico v Savi, tjakaj so jo peljali običajno s kobilo. ${ }^{63} \mathrm{Na}$ Drnovem, ki je najbolj oddaljena vas od regulirane Save, je bila navada pranja žehte na reki že zelo redka. Opravilo so opravljali največ 2 -krat letno, snetljivo žito pa je na Savi spiral komajda še kdo, še zlasti ne, če so imeli pri hiši že štirno. Kadar so Drnovci vendarle prali žehto na Savi, so zapregli kravo in vse peljali na plitvino pri brižansko-mrtviškem brodu, kjer so v plitvini perice ožemale rjuhe. ${ }^{64}$ Torej na isto lokacijo, kot Brižani in Mrtvičani v tem času. Ta predel je po savski regulaciji, zaobjemal še vse potrebne danosti tako za varen dostop, kakor tudi za nadalnje delo, ki je zahtevalo plitvino in ustrezno rečno dno. Ob vse bolj strmih brežinah, ki so nastajale v letih po rečni regulaciji še zlasti na zahodnem delu obravnave, je bilo takšnih mest postopoma vse manj.

\section{Lomljenje ledu in igre povezane z vodo}

$\mathrm{Tu}$ je bilo $\mathrm{v}$ zimskem času tudi priljubljeno $\mathrm{dr}$ sališče, kamor so v 1930-tih prihajali otroci raznih imenitnikov iz Krškega. ${ }^{65}$ Drsali ali sličali ${ }^{6}$ so s sliči, tj. z doma narejenimi drsalkami (Rihter 2015, I83, prim. Počkar 1998, 285), običajno iz lesenih polen okovanih s kosom železa ali žeblji, namesto vezalk pa so včasih porabili konjske cugle. ${ }^{67} \mathrm{~V}$ toplejših mesecih so tu pluli s kadujami, tj. lesenimi kadunjami za šopaje (goljenje) prašiča (Rihter 2015, I83).

Dolenjeskopiški pastirji so igrali igre na ledu na Šleglih (veliki in mali). Za lomljenje ledu pa

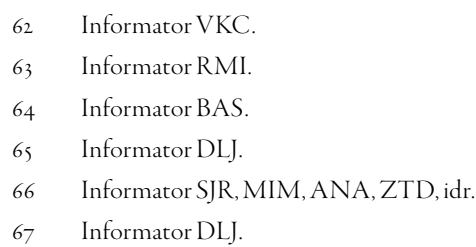


so bili skopičani angažirani v Brežicah, v Vrbini pod gradom.

Del iger je predstavljalo tudi plavanje. $\mathrm{Na}$ dolenjeskopiškem je imel Mali Šlegel plitvejšo vodo in je bil primeren za plavanje mlajših otrok, ker ni bil povezan z glavnim rečnim tokom. V Velikem šleglu je bila voda globlja. ${ }^{69}$ Plavali so tamkaj tudi na območju Pruda in Amerike. ${ }^{7}$ Brižani so se kopali v Savi na območju plitvine pri brodu. ${ }^{71} \mathrm{~V}$ vasi Brege se $\mathrm{v}$ zvezi z otroškimi igrami omenja plitva vodna površina na ledini Traminčki in Mlake pod vasjo, kamor se je v obcestni jarek ob nekdanjem jagnedovem drevoredu stekala vaška voda. Tu je prihajalo tudi do občasnega dviga talne vode. ${ }^{72}$ Drnovski pastirji so se kopali v vodi, ki je nekdaj zalivala jamo na Barovni pri ledini Za mlake.

\section{Gnoj iz mokrih kotanj ob poteh}

Med navadami manjših kmetov in sebenjkov v povezavi z mokrim svetom, je zanimivo še izročilo o »sebenkovem gnoju « z Breg, ki pravi, da so imeli sebenki iz drugih vasi, na brižanskem polju posejano po kakšno njivo koruze, ki so jo nato poželi, doma pa pokrhali štroke. Stebla - koruzenco pa so nasekljali na koščke in zvozili v kotanje na blatnih odsekih ob poti pri Barnopakah in dalje ob Gmajni. Tam so pustili, da so z vozovi vozili preko in se je zmes dodobra pregnetla z muljem. Na ta način so tudi sebenki prišli do gnoja, ki so ga nato razvozili po njivi. ${ }^{74}$ Gre za tod nekdaj razširjen princip namenske priprave kompostnega gnojiva $\mathrm{v}$ jamah - mlakah. V neposredni bližini naše obravnave, le onkraj Save, ga v župniji Videm leta I880 opisuje Dragotin F. Ripšl, ko pri opisu hišnih mlak pravi, da se v njih zbira deževnica, mulj, blato, listje, lubje, kratko rezana drozga ipd, kar vse se porabi naslednjo pomlad za gnojenje mladih trsov (Ripšl 2007,

68 Informator TXJ.

69 Informator ZXF.

70 Informator RCD.

7I Informator IFS, IKC.

72 Informator EKC, VER, IFS

73 Informator JAN.

74 Informator VER.
I46). V bližnji Veliki vasi so v 30-ih letih preteklega stoletja za potrebe gnojenja praznili mlako ob potoku v ravnini, ki je vanjo prinašal listje iz svojega zgornjega (gozdnega) toka. Še stoletje pred tem pa je bil tik ob tej mlaki, na srenjskih površinah tudi zelenjavni vrt, pri čemer njegova bližina verjetno ni naključna. Na Drnovem so z muljem iz vaških mlak (Kilarjeva in Jakševa mlaka) pri nekdanjem sejmišču bogatili le najrodovitnejše njive ledin Zevniki in Breg (Rihter 20I4, 39). Na Bregah izpričana navada izdelave gnoja ob mokrih obrobjih poplavne ravnice torej kaže, da ta proizvodnja ni bila rezervirana izključno za domače ali vaško okolje mlak, temveč se je lahko odvijalo tudi v poplavni ravnici, dlje od doma.

\section{Živinska paša in napajanje}

Živinska in konjska paša na obravnavanem območju je predstavljala najbolj razširjeno dejavnost. Zabeležili smo številna pričevanja o poteku in načinu paše ter kvalitetah in posebostih posameznih pašnikov. Paša je bila pretežno v domeni otrok in starcev. Temu prilagojene so bile ponekod tudi pašne razmere. Najmlajši otroci so pasli bližje domu, starejši dlje od doma v smeri reke Save. $S$ pašo so bile povezana tudi različne pastirske igre in znanja, kakršno je izdelovanje igrač in lesenih izdelkov za domačo uporabo ter nabiranje zdravilnih in drugih rastlin ter živali. Nekatere od teh omenjamo $\mathrm{v}$ pričujoči obravnavi. Zaradi obširnosti dejavnostih povezanih s pašo konj in živine, bodo te predmet ločene obravnave v prihodnosti. Trenutno izpostavljamo napajanje živine.

Sestavni del živinske in konjske paše je torej napajanje. To opravilo je zahtevalo večje količine primerne vode. Njeno zagotavljanje na nivoju vasi, je v času brez vododvodne napeljave, zahtevalo veliko skrb in napore, predvsem pa tvorno terminsko usklajevanje udeleženih pri skupnih vaških vodnjakih. ${ }^{75}$ Zato je bilo napajanje ob paši v poplavni ravnici nuja oz. njen sestavni del. Osnovna naloga tukajšnjih pastiric in pastirjev, je bila pašno žival v obe smeri pasti, nazaj grede,

75 Informator TTR 
ob poti, tudi napojiti. ${ }^{76} \mathrm{~V}$ obravnavanem času je bilo to še skoraj povsod možno. Vendar so bile že prisotne številne ovire, npr. neprimernost vode ali pa težka dostopnost rečne gladine reke Save na nekaterih odsekih brižansko-mrtviške vrbine, kjer se je Sava v novem kanalu do tega časa že znatno poglobila. Do izraza so zato prihajale vodne površine med reko in vasjo.

Poglejmo sedaj topografijo teh voda. $\mathrm{Na}$ skopiškem območju je bilo na gorenjeskopiškem, okoli $150 \mathrm{~m}$ dolga vodna površina na Spini (Vodopivec 2008, 77-78), na ledini Sredji prudi, se omenjajo v mrtvicah trije napajalniki ( Vodopivec 2008, p. 72, 77), to so omejena območja $z$ vodo v stari strugi. O njihovi osnovni rabi zgovorno priča ime samo. Globina najmanj enega med njimi je zahtevala plavanje živine pri prečkanju (Vodopivec 2008, p. 77) in prav tako na ledini Amerika. Na dolenjeskopiškem so bile vodne površine primerne za napajanje na več mestih vzhodno od ledine Studenec, in sicer: Dolenji prudi, Spinca/Veliki in Mali Šlegel. ${ }^{77}$ Te vode so dokončno presušile do 1960-tih let ali nekoliko kasneje. ${ }^{78} \mathrm{~V}$ vaseh zahodno od skopiškega območja so bila takšna območja površinsko manj obsežna. Na brižanskem: na ledini Globajnk (kjer se zaradi nevarnosti terena ni napajalo živine), Velike vode, Zlatičje, občasno, v jesenskem času, še na predelu Ločica in Delečki. Vodnata je bila tudi ledina Pod vrbam. Na mrtviško-vihranskem je bila voda na ledini Struga, Pod belim bregom in morda še kje v bližini Petrove škarpe. ${ }^{79} \mathrm{Na}$ Drnovem le na območju Mlak in deloma na ledini Barovna. Druge drnovske mlake, npr. Kilarjeva in Jakševa, niso bile primerne za napajanje živine.

\section{Paša gosi}

Pred drugo svetovno vojno so bile gosi, poleg kokoši tod najštevilčnejša perjad, njihova paša je bila najbolj povezana $\mathrm{z}$ mokrim svetom v neposredni bližini vasi. Na Bregah, kjer naj bi bilo,

\footnotetext{
76 Informator VER, EKC, IFS.

77 Informator RCD, STM, XSX, idr.

78 Informator ZXF.

79 Informator PAT, PAJ.
}

pred letom 194I po pričevanju, več gosk kakor rac, ${ }^{8 \circ}$ so poleg dveh s perutnino preobremenjenih vaških mlak, kjer je večja nosila značilno ime Račještališče, cenili čistejše vodne površine lučaj od vasi, na ledini Mlake in Pod vrbe, v sklopu velike ledine Gmajne. Tu je izpričana tudi paša koz, od perutnine pa so se tu v največji meri pasle gosi, ki so tod našle kvalitetnejšo pašo, kot $\mathrm{v}$ umazanih vaških mlakah. Te so številčno prevladovale nad racami, saj so jih - poleg mesa - cenili zaradi najfinejšega perja za posteljnino in peruti za omela $^{81}$ ter zaradi obrednega pripravljanja (božične) zdravilne maščobe. Nesoljena surova maščoba gosi v posodi, je bila na Bregah sestavni del jaslic in s tem božičnega blagoslova. Takšna se je stalila in se uporabljala skozi vse leto za zdravljenje. Gosjemu perju je po kvaliteti sledilo račje, ki pa je bilože težje in manj zaželjeno. Kokošje pa je zaradi svoje težine sploh veljalo za najslabše. ${ }^{82} \mathrm{Na}$ Drnovem so za posteljnino tedaj cofali perje še domala pri vsaki hiši ${ }^{{ }^{8} 3}$ dejavnost pa je pomenila tudi pomemben socialni vidik, zimskega druženja predvsem ženskega dela domačije.

$\mathrm{Na}$ Drnovem so gosi in race zahajale v obe vaški mlaki, tj. Kilarjevo in Jakšavo. $\mathrm{V}$ njih je voda človeku segala do pasu, na gladini pa je od pregretosti in preobremenjenosti $v$ vročih dneh plavala »zelena smetana«. ${ }^{84}$ Paša gosi je bila na Drnovem razširjena tudi na območju ledine Mlake v smer vasi Brege. Tam je šlo za večje in čistejše vodne površine, kot posledice dviga talne vode (Rihter 2015, I83-185). Tod zelo razširjena vrsta domačih rac so bile t. i. gluhe race ali mutke, ki so bile običajno tudi letalke. Tudi domače gosi so bile tedaj vsaj deloma še leteče. Paša teh je bila prosta, človekova prisotnost ob paši pa nepotrebna. Največ gosi je premogel vaški predel Kot, ki je bil najbližje vaškima mlakama:

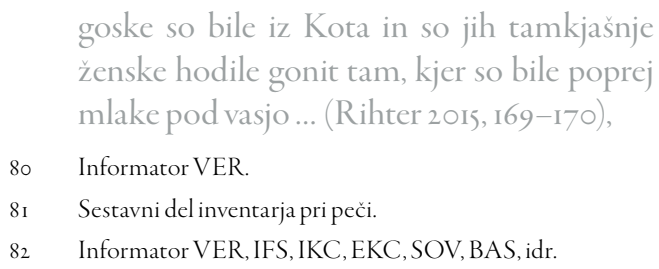


pa tudi obcestni del Fara, kjer so imeli do 25 gosi na hišo, ni zaostajal. ${ }^{85}$ Preprost izračun pove, da je občasno šlo za stotine gosk, kakor tudi sicer poriča izročilo in spomini. Gosi so na pašo hodile tudi same v gosjem sledu ali pa so iz dvorišč nad staro brežino poletavale $\mathrm{v}$ mlake in se od tam pred večerom tudi vračale. ${ }^{86}$ Opoldne so gospodinje prihajale $\mathrm{k}$ mlakam $\mathrm{z}$ žitnim zrnjem, da bi iz jate priklicale svoje gosi in jih nahranile. Pred večerom so jih prišle včasih ponovno iskat. ${ }^{87}$ Preverjali so število vrnjenih gosi in po potrebi (manjkajoče), iskali v mlakah, kjer so navadno zaostale zaradi poškodb ali nenadne obolelosti.

O dobrih pogojih za rejo perutnine v Posavju v 2. polovici 19. stoletja piše Ferdinand Ripšl, za sosednjo, videmsko župnijo onkraj Save, kjer naj bi nekatere vrste pa so ob pitanju dosegale nenavadne velikosti. Gosi so naprimer pri pečenju dajale tudi 2 dunajska funta masti (tj. I, I2 kg). Sloves videmske perutnine je tedaj segal daleč preko meja Štajerske (Ripšl 2007, I58). Reja, kokoši, rac, gosi in puranov je bila nasploh značilna za Krško polje v času konec i9. stoletja in v začetku 20. stoletja. Prav tako prekupčevanje z jajci, kjer se v Brežicah omenja »jajčni kralj« (D. S. I930, II), podobno tudi na Drnovem od koder je Vene Franc st. vozil jajca v Zagreb in v Trst (Rihter 2015, 176).

Gosi so bile še pred desetletji tod zelo pomembna vzrejna vrsta povezana $\mathrm{z}$ mokrim svetom. $\mathrm{Z}$ spremenjenimi navadami prebivalstva, modernizacijo dvorišč in novih podob vasi, opremljenih z elementi, ki so značilnejši za mesta ter $\mathrm{z}$ spremembami $\mathrm{v}$ dostopnosti do (nekdanjih) skupnih vaških površin in nenazadnje, $\mathrm{z}$ osušitvijo mokrega vaškega okolja, je reja gosi po vaseh skoraj povsem zamrla.

\section{Paša (krškopoljske pasme) prašičev}

$\mathrm{V}$ kolikor spregovorimo o paši prašičev $\mathrm{v}$ poplavni ravnici Krškega polja, pravzaprav govo-

\footnotetext{
85 Informator EDA.

86 Informator DMD

87 Informator EDA

88 Informator DMD.
}

rimo tudi o izvornem življenjskem okolju avtohtone krškopoljske pasme prašiča.

Krškopoljska pasma je predstavljala edino pasmo, ki so jo pred vojno tod redili, ${ }^{89}$ pravili pa so ji pasasta sorta, ${ }^{\circ}$ ki se ji je po vojni pridružila in pomešala še t. i. hrvaška sorta ${ }^{91}$ in druge (prim. Rohrman I899, 9; Počkar 200Ib, 577; Šalehar 2015). Zato pred obravnavo njegovega pašnega zaledja spregovorimo še nekaj o splošnih podatkih o povezavi te pasme $\mathrm{z}$ našim območjem.

Viljem Rohrman, ki prvi podrobno opisuje krškopoljskega prašiča, je izpostavil značilno območje njegovega življenjskega okolja pri Šentjerneju, ob Krki in ob Savi, na Krškem polju (I899, 9). Skupna značilnost v vaseh, ki jih našteva kot najpomembnejše pri vzreji krškopoljskega prašiča, je bližina mokrotnega obrobja Krakovskega gozda ali poplavnih ravnic Krke in Save. Drnovo poimensko izpostavlja kot pomembnejše vzrejišče, ob tem pa tudi kot enega štirih največjih središč za trgovanje s temi prašiči (Rohrman I899, 9-10). Na Drnovem so bili namreč od leta I855 dalje trije letni, veliki svinjsko-živinski in kramarski sejmi, na ledini Gmajna v stari savski strugi, in sicer: $\mathbf{1 2}$. marca , 24. junija in 29. septembra to so bili t. i. Gregorjev, Janezov in Mihelov sejem (Rihter 2015, I85-189). V I920-tih letih so krškopoljske prašiče prodajali po 8-ıo tednov stare na Notranjsko, Goriško, v Istro in v nemške avstrijske dežele, še poprej pa tudi na Gorenjsko in na Kočevsko (D. S. 1930, II). S tem se naše območje krškopoljskih vasi, s poplavno ravnico in zaledjem rodovitnih njiv, opredeljuje kot temeljni življenjski okoliš krškopoljskega prašiča, kjer je bilo hkrati zadoščeno tako gojitvenin, kakor tržnim potrebam in kjer zlasti izstopa vloga vasi Drnovo. Vas Drnovo, ima za razliko od ostalih petih v sklopu naše obravnave, ohranjene še nekatere prvine stare poljske razdelitve, ki bi je bilo - če ne iz drugačnih razlogov - nemara vsaj zaradi povezave $s$ krškopoljsko pasmo, nujno ohraniti kot tako. Poglejmo zakaj.

\footnotetext{
89 Informatorja TTR in STM.

90 Informator MIM, TTR, SJR, IFS, VER, idr.

91 Informator IFS
} 
Krškopoljčeva anatomija kratkega in močnega vratu $\mathrm{z}$ močno razvitim rilcem, pripravnim za pašo (Rohrman I899, IO), pravzaprav kaže na mokrotno okolje v katerem je živel in se razvijal. To okolje, kot smo videli v uvodu, zaradi človekovih posegov v prostor danes ni več ohranjeno. Ohranjeni pa so zadnji segmenti tedanje, stare poljske razdelitve pri Drnovem (Rihter 2015), ki izvira še iz fevdalne dobe, ki pa je prav tako sestavni del z rejo tega prašiča povezane pokrajine. Tako se je na celotnem obravnavanem prostoru spodnjega polja med Dolenjimi Skopicami in Drnovim, do dandanes z originalno poljsko razdelitvijo na delce, ohranilo komaj za vzorec polja, to je približno $1,5 \mathrm{~km}^{2}$ spodnjega polja severno pod vasjo Drnovo. Gre za edinstven preostanek mozaične pokrajine, ki v zadnjih letih posepešeno izginja $z$ intenziviranjem kmetijstva. Upamo, da bo ta ostanek starega polja v poplavni ravnici kmetijska in turistična stroka ob spodnji Savi, predvsem pa v občini Krško, če ne drugače, ob razvijanju projekta Črno-belo bogatstvo s Krškega polja, katere končni cilj je razvoj nove lokalne turistično-kulinarične ponudbe-produkta, temelječe na avtohtoni slovenski pasmi krškopoljskega prašiča (prim. Šubic 20I8), prepoznalo kot zgodovinsko izvorno zaledje reje in paše krškopoljskega prašiča ter staro delitev polja prav zato ohranilo in jo vključilo v celotno podobo t. i. »produkta « ali morda bolje, tudi v njegovo rejo. Reja krškopoljca je bila namreč tesno povezana z mozaično kulturno pokrajino in ni nikoli temeljila na intenzivnem kmetijstvu, kakršne predstavljajo in spodbujajo današnje, tod pred kratkim komasirane zemljiške površine. Drnovsko spodnje polje (trenutno, september 2019) torej še vedno, na celotnem krškem polju med Brežica$\mathrm{mi}$ in Krškim, edino še ohranja avtentično podobo iz časa fevdalne ureditve zemljišča (Rihter 2015). Čeravno je takšna parcelacija za trenutne, tod porajajoče se intenzivne oblike kmetijstva, povsem neprivlačna, bi lahko šlo na Drnovem, ob prepoznavanju naštetih dejstev, kot ključnih in pomembnih za celotno podobo te avtohtone pasme, za posebno danost in za priložnost.
Del mozaične podobe drnovskega spodnjega polja bi se moral ohraniti, kot vzorčni del stare, krškopoljske kulturne pokrajine; toliko lažje, v kolikor bi se spojila s kakšno izmed neintenzivnih in ekološko vzdržnih kmetijskih dejavnosti, kakršno npr. zahteva avtentična reja krškopoljskega prašiča. Ozadje avtentiče reje teh prašičev pa pomeni mdr. tudi neintenzivno pridelavo krme, s katero je krmljen. V praksi bi to lahko pomenilo spodbudo za oživitev kakšne izmed starih drnovskih kmetij, ki še razpolagajo z nekomasiranimi zemljišči na spodnjem polju, t. j. z okoli IO-I2 parcelami v različnih delih spodnjega polja.

Za nazornejšo ilustracijo nekdanjega življenjskega okolja krškopoljske pasme, navajamo nekdanjim našim razmeram sorodne in še danes ohranjene poplavne ravnice iz soseščine, dolvodno ob Savi na Hrvaškem, v parku Lonjsko polje. Tu še vedno izvajajo t. i. žirjenje svinj (pašo plodov) v hrastovih gozdovih, kakor tudi običajno pašo. Pašna živinoreja se tam izvaja na poplavnih travnikih, ki so hkrati tudi pomembna ribja drstišča. Velika okoljska pestrost se odraža tudi na številu živalskih vrst, ki tam domujejo. Zato ne preseneča, da je ravno tam koncentracija avtohtonih hrvaških živalskih pasem največja. Tu namreč domujejo turopoljski prašič, posavska gos, med konji - hrvaški posavec in hrvaška hladnokrvna pasma in slavonsko-sremsko podolsko govedo (Gugič 2006, 6 in II). Takšna okolja so na našem prostoru že dolgo izgubljena, nekaj možnosti za ohranitev mozaične pokrajine pa je vendarle še ostalo, kakor smo pokazali in opozorili v zgornjem odstavku ter nadaljujemo v naslednjem.

Povrnimo se sedaj v mokro okolje Drnovega in pašo prašičev. Nekdanje mokro okolje obeh vaških mlak (t. i. Kilarjeve in Jakševe mlake), v stari savski strugi v sklopu skupnega pašnika Gmajna, je bilo tipično in za celotno vas osrednje mesto paše številnih živali. Zgoraj smo že omenili tukajšnjo pašo stotin gosi, ki se jim pridružujejo tudi race, med njimi pa so bili tudi prašiči:

na gmajnah so bile svinje, ki so jih kar nagnali na pašo in koder je bila trava, so se ustavile 
in same pričele pasti. Njih paša je bila lahka, ker so bile ubogljive (Rihter 2015, I69-170).

Mirna narava in krotkost krškopoljskih prašičev je značilnost te pasme (Rohrman I899, Iо; prim. Počkar 20orb, 577). Na drnovski Gmajni se je pred drugo svetovno vojno zmeraj paslo nekaj svinj. ${ }^{92}$ Nekateri vaščani Viher so imeli možnost paše svinj v hrastovem gozdičku ob strugi pod vasjo (Rihter 2010, 30). Tam so ob in v stari savski strugi na SV delu vasi, na vaški zemlji, kjer je rasla robinja in grmovje, $v$ času pred in po drugi svetovni vojni delom še pasli prašiče. ${ }^{93}$

$\mathrm{Na}$ Bregah so se svinje pasle ob stoječi vodi na ledini Pod vrbam. ${ }^{94}$ Izpričan je tudi spomin na svinjsko pašo »pred več kot sto leti $\ll,{ }^{95}$ ki se je izvajala dlje od vasi, na območju močvirnega Globajnka in neposredne okolice, kjer naj bi se svinje tudi kalužale $\mathrm{v}$ blatu. $\mathrm{V}$ prid tej navedbi govori podatek iz leta 1893 , ki pravi, da je neki Urbanč z Breg zahteval odškodnino mdr. za 6 svinj, ki jih $\mathrm{v}$ času vojaških vaj topničarjev ni mogel pasti. ${ }^{96}$ Ker pa vemo, da je poligon za topničarske vaje na brižanskem spodnjem polju zajemal področje severno od vključno ledine Globajnk (Rihter $2016 \mathrm{~d}$ ), to pomeni, da se je brižanska prašičja paša tedaj, izvajala na pašnikih globlje od Globanjka proti reki Savi. Torej od vasi več kot $\mathrm{I} \mathrm{km}$ globoko v poplavni ravnici (Sl. I). V prvi polovici 20. stoletja pri Globajnku prašičev niso več pasli. ${ }^{97}$ Prašičja paša na skupnih gmajnah je bila v Posavju nasploh običajnejša pred I. svetovno vojno (prim. Počkar 200Ib, 579), pa tudi drugod. Omenjena poročila o prašičji paši globlje v Vrbini so torej sled starejših oblik reje prašičev, v našem primeru gotovo deloma povezane tudi z starejšo, manj osušeno podobo poplavne ravnice na območju zaledja Breg, pa tudi z spremembami v načinu kmetovanja. Na Kranjskem je prašičjereja prešla iz pašnega gospodarstva v hlevsko rejo v drugi polovici 19. stoletja. Prehod so pos-

92 Informator VVK.

93 Informator PAT.

94 Informator OFL, IFS, EKC.

95 Informator OFL

96 Dolenjske novice (15. I. 1893).

97 Informator IFS. pešile nove agrarne razmere $\mathrm{v}$ pomarčni dobi in večje izkoriščanje krmnih kultur in okopavin (krompir, koruza, pesa, detelja), ki so jih začeli na Kranjskem uvajati v skladu s fiziokratskimi prizadevanji. Povedano drugače, je prehod na hlevsko rejo, ki je bila sicer zahtevnejša, a donosnejša, zahteval privatno lastnino, potekal pa je vzporedno z razkrojem fevdalne agrarne strukture (Britovšek 1964, I45-146).

\section{Mokri svet in nadnaravno}

Človekove dejavnosti v poplavnem svetu so spremljala tudi nadnaravna doživetja, zato je prav, da jih enakovredno predstavimo. Opazna so relativno pogostejša pričevanja o nadnaravnih doživetjih $\mathrm{v}$ poplavni ravnici in na njenih robovih, kakor na zgornjem polju. Časovni seštevek tistih dejavnosti v poplavni ravnici, ki smo jih že opisali in tistih, ki jih bomo v nadaljevanju, jasno pokaže, da je človek tam preživel več časa, kot na zgornjem polju. Prisotnost človeka v zgornjem polju je bila vezana večinoma na obdelavo njiv, oskrbo posevkov in na žetev. To seveda časovno ni bil majhen zalogaj, vendar v skupnem mnogo manjši, kot tisti, preživet $v$ poplavni ravnici. Gibanje $\mathrm{v}$ poplavni ravnici $\mathrm{v}$ večernem in nočnem času, še zlasti pa v gluhi dobi noči, ki so jih občasno zahtevala različna opravila ali poti (npr. košnja, žetev), so človeka pogosto soočala z nadnaravnim. Tu se ne želimo spuščati $\mathrm{v}$ različne vidike razlag teh pojavov in povezav naprimer $\mathrm{z}$ različnimi mejami v prostoru, ki imajo $\mathrm{v}$ tradicijskih verovanjih pomembno vlogo (npr. Hrobat 2009; Mencej 2006) in so bile v tem oziru na območju Drnovega deloma že obravnavane (Rihter 2015, 206-285; 2017, 71-76). Predstavljamo zgolj kratek prostorsko umeščen pregled pričevanj o nadnaravnem, pričenši na skopiškem območju.

Nekatere dolenjeskopiške kmetije naj ne bi prale perila ali svinjskih črev na Savi, zaradi prisotnosti Babe, tj. velikanke z dolgimi nogami, dolgim krilom in rdečo ruto, ki je prala na Savi. Temu so se nekateri izognili tako, da so raje hodili prati na bližnjo reko Krko. ${ }^{98}$ Motiv velikanke, ki pere na Savi ali pa stoji z eno nogo levem

98 Informator ZHK. 
ali desnem bregu Save je tod sicer dobro znan in razširjen (Rihter 2015, 204). Vendar je običajneje povezujejo $\mathrm{z}$ dejanji, ki posegajo $\mathrm{v}$ arheološke ostanke, npr. prestavljanje rimskih kamnitih ostankov, kjer pa lahko to isto delo opravlja tudi moški lik - velikan (Rihter 2015, 204, 23I in 25I). Na območju ledine Perišče v zaledju G. Skopic, so znana pričevanja o pojavljanju lučk v nočnem času. ${ }^{99}$ Nedaleč od tu, na dolenjeskopiškem, na območju Luga, Marofa in Javšine, so gibanje v prostoru, $\mathrm{v}$ določenih smereh omejevale kače in tudi kača, ki čuva zaklad. ${ }^{100}$ Prisotnost kače, sicer s človeško glavo, je znana iz zaledja Mrtvic na ledini Struga. ${ }^{\text {IO }}$

Pričevanja o sledi božjega kosca v žitu, sicer vidne le v času žetve, so, kakor se zdi trenutno, pogostejša za spodnje polje. Šlo naj bi za več desetin metrov dolge ravne črte $\mathrm{v}$ žitu preko več njiv, ki so jih povezovali z onostranskimi, »božanskimi« znaki zadovoljstva nad dobro žitno letino. Pojav je bil omejen le na leta $z$ dobro letino. Sledi, ki jo povezujejo z božjim koscem, opisujejo na Gorenjih Skopicah, Bregah in na Drnovem (Rihter 2015, 208). Z Breg je znana v spodnjem polju na ledini Mrtvišce. ${ }^{\text {I02 }}$ Nek nepojasnjen dogodek v žitu na ledini Sarkovšče, ki je imel za posledico uničeno žito, je prav tako znan z Breg. ${ }^{\text {103 }}$ Vasi Brege prvi in najbližji skupni pašnik na območju ledine Gmajna, je bil na severovzhodnem obrobju omejen $\mathrm{z}$ vodnato in močvirno ledino Globajnk, kjer je po izročilu bival povodni mož. Njegova prisotnost je zlasti močno omejevala gibanje pastirjev. ${ }^{104} \mathrm{Ob}$ tamkajšnjem pomembnem razpotju, kjer ima $\gg$ baba noge narazen $\ll,{ }^{\text {105 }}$ na zahodnem obrobju pašnika Gmajna ob poti na Remen, je znan prostor pojavaljanja prikazni ženske s trugo (Rihter 2015, 254). Iz poplavne ravnice onkraj reke Save, je znan nočni kosec prikazen, ki kosi na drugem koncu travnika na-

99 Informator BET.

Ioo Informator ZHK

IOI Informator XMR.

IO2 Informator EKC, VER

IO3 Informator KHR.

I04 Informator VER, EKC, IFS

Ios Informator DIN. S tem izrazom opisuje križiščce Y-oblike. sproti dejanskemu koscu - pričevalcu (Rihter 2015, 268).

Pomembna prostorska točka je širše območje podružnične cerkve sv. Urha na Vihrah, ki stoji ob cesti, ki tam prehaja iz zgornjega polja $\mathrm{v}$ poplavno ravnico. Tamkajšnja nadnaravna srečanja zajemajo širok spekter izročil, ki se pojavljajo med ledino Pri križi in cerkvijo. Med njimi je zlasti zanimiva prikazen nevarne divje svinje z I2 mladiči ter izročila o prestavljanju cerkve, utopljenem dečku v jezeru, naplavljenih cerkvenih vratih, o lesenem gradu in drugih nenavadnih doživetjih (Rihter 2015, 240), pridružujejo pa se jim še $z$ arheološkimi ostanki povezana izročila o rimskih vratih (Rihter 2017,64 ). Približevanje cerkvi je bilo pri nekaterih skopiških hišah dovoljeno le v času maše na dan sv. Urha, ki je mdr. naznanil tudi pričetek izkopavanja mladega krompirja za hrano. Nasploh je bila tudi sama cerkev nosilka nadnaravnih pojavov, saj naj bi mimoidoči bili vedno znova vznemirjeni nad prižiganjem luči in občasno (ne)zastrtimi okni. ${ }^{106}$ Vihranska ledina Brodišče pod Brežnicami, ki predstavlja večperiodno arheološko najdišče (Pergar in Rihter 2008, 297), kjer naj bi v času turkov deloval brod (Rihter 2010, 32-33; 2015, 278; 2016, 242) in ledina Zgorelo v poplavni ravnici, sta $\mathrm{v}$ izročilu povezani s čarovnicami, kot lučkami. ${ }^{\text {x }}$

Z Drnovskega območja so znana številna pričevanja o nadnaravnih doživetjih, zlasti z območij, ki mejijo na poplavno ravnico ali pa so $\mathrm{v}$ starih strugah. Npr. o divji jagi v strugi na relaciji Drage-Gauge-Žadovinek, o velikem človeku - nemem spremlejvalcu na cesti ob strugi med drnovskim Belim bregom in Zevniki, ali mrtvecu, ki preko Drašč sledi koscem na ledino Remen, idr. (Rihter 2015, 254-260, 267). Izstopajoč prostor $s$ posebno nadnaravno veljavo na tem območju izstopa ledina Gauge pri brižanskem Belem bregu (Rihter 2008), severno od Drnovega, ki zajema staro savsko brežino, na križišču in stiku katastrskih mej. Tamkajšnjim različnim pojavom, od nočnih lučk, izročil o obešanju ljudi,

I06 Informator ZHK.

107 Informator PAT, CAR 
o zbirališču čarovnic, o nasilnih čarovnicah, ki lovijo mimoidoče, do strašljivih zvokov, idr., se pridružujejo pričevanja o nenavadnih doživetjih tudi $\mathrm{z}$ ledin $\mathrm{v}$ neposredni bližini (Rihter 2015, 257-258, 262). Ledina Mlake, v stari strugi pod vasema Drnovo in Brege je bila splošno znana po nočnih lučkah, sam prostor na območju arheoloških ostalin Nevioduna, pa tudi kot zbirališče čarovnic (Rihter 2006; 2015, 244-245).

Številna pričevanja o nadnaravnih elementih $\mathrm{v}$ poplavni ravnici, torej logično odražajo intenzivnost človekove prisotnosti v njem, predvsem pa jo $\mathrm{v}$ percepciji prostora postavljajo enakovredno med sestavne dele vaških celot. Poplavna ravnica se torej tudi preko nadnaravnega ponovno kaže kot neločljiv in sestavni del vsake vasi.

\section{Nabiralništvo}

Sledijo opisi navad vsakovrstnega nabiranja rastlin in živali v poplavni ravnici, s kratkim dodatkom o lovu. Pri tem imejmo v mislih, da so bile ob tem na zgornjem polju le njive in zelo redki travniki, še manj pa je bilo pašnih površin. $\mathrm{Z}$ grmičjem poraslih površin skorajda ni bilo. Zato je bilo večina nabiralnišstva skoraj izključno vezana na poplavno ravnico. $V$ nadaljevanju obravnave je delitev na hrano za živali in za ljudi vzpostavljena arbitrarno, za potrebe lažjega pregleda in drži le v grobem. Vemo namreč, da sta se obe skupini po namenu pogosto prepletali, najpogosteje vobdobjih pomanjkanja.

\section{Hrana za živali}

Podroben vpogled $\mathrm{v}$ nabiralništvo $\mathrm{v}$ poplavni ravnici pred letom 194I, nudijo pričevanja tedanjih sebenjkov, pa tudi kmetov, v zvezi z dopolnjevanjem prašičje krme. Tudi tu, kakor pri paši je ključno vlogo nosilo prav spodnje polje. Za robovi strug in ob mejnicah srenjskih pašnikov ter ob poteh, je bilo moč s prosto rastočimi rastlinami znatno dopolnili primanjkljaje krme, kar je prišlo do izraza še posebej spomladi, v času po setvi in pred žetvijo, ko je bilo pomanjkanje največje. Strah pred izgubo te možnosti ilustrira te- danje ljudsko razmišljanje, ki je postalo sedaj, ob komasaciji zemljišč ponekod zopet aktualno:

\section{Pravili so že tedaj, da ko bodo veliki kmetje strnili svoje njive skupaj, majhnim ne bo os- talo niti za kozo napasti ob poti. ${ }^{\text {1.8 }}$}

Na Drnovem so pri neki dninarski hiši v I930-tih za svinjski kotel ${ }^{109}$ pleli po stari savski strugi ob njivah in mejah proti severu, vse do ledine Gauge. Nabirali so mladi osc (osat) in modrušo, ki naj bi cvetela $\gg$ rdeče in zeleno $\ll{ }^{\mathrm{IIO}} \mathrm{oz}$. modro, med žitom ${ }^{\text {III }}$ ter mlečk, ki so mu pravili tudi frauca, kakor so imenovali spodnji del maka (Papaver sp. ) v času pred razvitejm cveta. Na boljši zemlji, v svižnatem ${ }^{112}$ na pašniku Barovna so nabirali še lapuhovo listje (Tussilago farfara), ki so ga svinjam kuhali skupaj s koprivami (Urtica sp. ), bezgovim listjem (Sambucus sp. ) in slakom (Convolvulus arvensis) skupaj z žiti. ${ }^{113}$ Pri neki drugi kmetiji na Drnovem so dopolnili kotel v kobinaciji kopriv, osata, fravce in slaka (Convolvulus arvensis), ${ }^{\mathrm{Ir} 4}$ ponekod so v kotlu nad žito (ječmen in koruzo) dajali le lapuh. ${ }^{\text {II5 }}$ Lapuh je bil običajno sestavina kuhanih obrokov, surovega niso pokladali. ${ }^{116} \mathrm{Na}$ Barovni so za kotel nabirali še velike liste parkla (verjetno Heracleum sphondylium), ki so ga skupaj s koprivami in bezgovimi listi kuhali nad ječmenom $v$ pečeh. ${ }^{\text {II7 }}$

Io8 Informator SOV.

I09 Z izrazom svinjski kotel označujem - kakor danes informatorji svinjsko skuho, čeravno se je ta v času, ki ga obravnavamo, izvajala še skoraj izključno v krušnih pečeh v svinjskih loncih iz lončenine in ne v kotlih. Informatorji že zelo dolgo v te namene uporabljajo brzoparilnike, ki mu pravijo kotel. Sprva so ponekod imeli njegovo predhodno različico, tj. obzidano litoželezno posodo - kotel. S to napravo je povezan že tudi nov prostor, to je t. i. svinjska kubna, ki je bil tod, pred 2. svetovno vojno, kot zidan in samostojen prostor, še izjemno redka zgradba. Ena prvih je bila na Škrabčevi domačiji na Bregah že v 1930-tih letih., kjer je bil v istem času zgrajen tudi eden prvih objektov z armirano litobetonsko stropno ploščo.

I IO Informator TTR

i i Informator EKC.

II2 Rečne naplavine najdrobnejšega peska tod imenujejo sviž.

I13 Informator TTR.

I1 4 Informator ALS.

i15 Informator VMA.

I16 Informator IFS.

I17 Informator EDA. 
Slak so tod, med pleveli, poleg kopriv, prištevali $\mathrm{k}$ izdatnejšim krmilom. $\mathrm{Na}$ Bregah so kmalu po skopnenju snega za prašiče nabirali ostk (osat) in frauco, kasneje tudi sunogo, ki je rasla po nezoranih njivah. Našteto so pokladali prašičem večinoma surovo. Enako tudi vodiko ${ }^{\mathrm{II} 8}$ ali vodenko, ${ }^{\mathrm{II} 9}$ ki so jo želi po Vrtih in ob močvirnih predelih. ${ }^{\text {I20 }}$ Špela Pungaršek (Prirodoslovni muzej Slovenije) je vodenko, ki jo je v naravi poiskala Vera Jurečič z Breg, identificirala kot navadno krišino (Parietaria officinalis). Sunogo, ki jo je v naravi poiskala Elka Grilc, pa kot smrdljičko (Geranium robertianum) (Pungaršek, Š., osebna komunikacija, Io. 5.2016 in I. 7. 2016). Tudi regač (navadni svinjak, Hypochaeris radicata), ki se je na Bregah trebil iz travnikov in z njiv kot plevel, so dajali svinjam skupaj z navadnim regratom kar surovega. ${ }^{\mathrm{I2I}} \mathrm{Za}$ svinjsko skuho so na Bregah nabirali koprive in slak ter ostk (osat). ${ }^{122} \mathrm{Ob}$ omembah osata dodajamo še, da so ga povsod tod uporabljali tudi za prvo pomoč pri urezninah (poleg lastnega urina) in drugih poškodbah na polju. Osat so zmehčali v dlani, da se je pocedil sok, ki so ga nanesli na rano. ${ }^{123} \mathrm{Ob}$ lapuhu kot krmi, je znana tudi njegova razširjena uporaba pri toaleti za veliko potrebo. ${ }^{124}$

Ivanka Počkar je pri obravnavi različnih vidikov domače svinjereje v Posavju, med hranili zabeležila tudi koprive in lapuh (200Ib, 578 ), v podobnih kontekstih krmljenja s kuho, kot smo jih zabeležili v naši raziskavi.

\section{Hrana (rastlinska) za ljudi}

Bezgovo cvetje in cevtje hacane ali gacje (tj. robinje; Robinia pseudoacacia), ki so ga nabirali ob poraslih brežinah, so tod povsod cvrli v tajgu (tj. jajčnem testu) za posladek. Omenimo še, da so donedavno njeno listje skupaj z vejami sekali

I18 Informator IFS

I I9 Informator VER, EKC.

I20 Informator IFS.

I2 I Informator VER.

I22 Informator VER

I23 Informator VER, EKC, TTR, idr.

I24 Informator MIM, VER, ANA, idr. tudi za krmo kuncem v prosti reji v hlevu, ${ }^{\mathrm{I} 25} \mathrm{ki}$ so jih tod redili pred drugo svetovno vojno. ${ }^{126}$ Pomladno nabiranje regrata (Taraxacum Weber sp. ) in motovilca (Varianella Mill. sp. ) po strniščih in drugod je bilo splošno prisotno še nedavno. Motovilec v času prve polovice 20. stoletja ni bil (skoraj) nikjer vrtni posevek, temveč samorasli strniščni pridelek, nabiral pa se je, kakor regrat, tudi za prodajo na trgu v Krškem. Najboljši regrat in najlažje dostopen (rahla zemlja) je izviral iz polja v poplavni ravnici. Pri regratu za živalsko hrano je ponekod šlo za temnozelene, bohotne nadzemne dele regrata, ki uspevajo ob poteh in na travnikih. Teh večinoma niso uporabljali za ljudsko prehrano, kot je to $v$ navadi dandanes. Še nekako do začetka 9o-ih let 2o. stoletja je bil tod bolj cenjen beli, podzemni del regrata, ki se je spomladi kopal ob robovih jeseni preoranih strnišč njiv ali travnikov ter deteljišč ali pa v krtinah. Regrat je spomladi pognal iz globine preko ornice na površje, pri tem pa ustvaril dolg bel podzemni del, ki je spominjal na radič. Mešane solate $\mathrm{z}$ regratom so tedaj $\mathrm{v}$ zgodnjepomladanskem času marsikje večkrat predstavljale glavno oz. samostojno jed celotne družine. V povojnem času so globoko koreninjen regrat $\mathrm{v}$ razmeroma mehki ornici običajno ruvali z vojaškimi bajoneti, ki so tod ostali še iz časov nemške okupacije. V 90-ih letih preteklega stoletja je regrat, kakor tudi motovilec, z njiv postopoma izginil skupaj z drugimi vrstami plevi, najverjetneje kot posledica uporabe herbicidov.

Nabiranje travniških kukmakov - šampinjonov na travnikih in strniščih žit v spodnjem polju ni mogoče, saj uspevajo izključno na zgornjem polju (pleistocenska terasa). $\mathrm{V}$ poplavni ravnici pa so nabirali predvsem štorovke na deblih topola. V okviru domačih vrtov pa največ na slivovih štorih. ${ }^{127} \mathrm{Na}$ Vihrah so jih nabirali pri belih topolih na ledini Podjagendi. ${ }^{128} \mathrm{~V}$ G. Skopicah so spomladi v manjši meri uživali še listje gabeza (Symphytum sp.), ki so ga pome-

I25 Informator TTR

I26 Informator VER

I27 Informator SIR.

I28 Informator MRI 
šali v jajčno cvrtje, $v$ poznem poletju pa na isti način tudi ob reki nabran divje rastoči hmelj (Humulus sp. ) in še nekatere druge mlade poganjke rastlin, ${ }^{129}$ med njimi npr. kopino tudi $\mathrm{v}$ čaju. ${ }^{{ }^{30}}$ Podobno, v jajčnem cvrtju, na Bregah, le v zdravilne namene tudi poljac (Mentha pulegium) (gl. Zdravilne ...).

Še zlasti pastirji so dobro poznali oz. vedeli za rastišča plodonosnih grmovnic. $\mathrm{Ob}$ poti v Vrbino so na G. Skopicah obirali maline in drugo plodonosno grmičevje (Vodopivec 2008, p. 7I-72). Sicer pa so se skopiški otroci v Vrbini sladkali še $\mathrm{z} \gg$ vlašicami ${ }^{1331}$ kakor so imenovali neko vrsto jagodičevja (Rihter 2010, 30), pa tudi z medvedovimi hruškami (glog; Crataegus sp. ), trnulami (črn trn), ipd. ${ }^{\mathrm{I32}} \mathrm{Na}$ drnovskem območju so za prehrano nabirali tudi plodove črne in bele murve (Morus sp. ) ter divjih češenj, ki so tod še dandanes razširjena drevesa. Murve so po izročilu ostanek sviloprejske dejavnosti povezane $\mathrm{z}$ velikovaško graščino (Rihter 2014, 79). Na Drnovem tarnul (črni trn) omenjajo za kuho marmelade (Rihter 20ı, 33). Tudi iz gloga so ponekod kuhali marmelado, ${ }^{133}$ iz češmina pa napravljali kis. ${ }^{134}$ Pastirji z Breg so žvečili in (ali) jedli: češmin ${ }^{135}$ (Berberis vulgaris), trnule (črni trn; Prunus spinosa), ${ }^{136}$ medvedove hruške, lešnike (Corylus avellana), divje jagode (Fragaria sp. ) kopine (robida; Rubus sp. ), kislico (Rumex acetosa), gartrože (šipek; Rosa sp. ), črna semena dobroletine (Viburnum lantana) in srkali cvetni med kozjega zizka (kovačnik; Lonicera caprifolium). ${ }^{137}$ Preseneča redkost drena tedaj, kakor še danes:

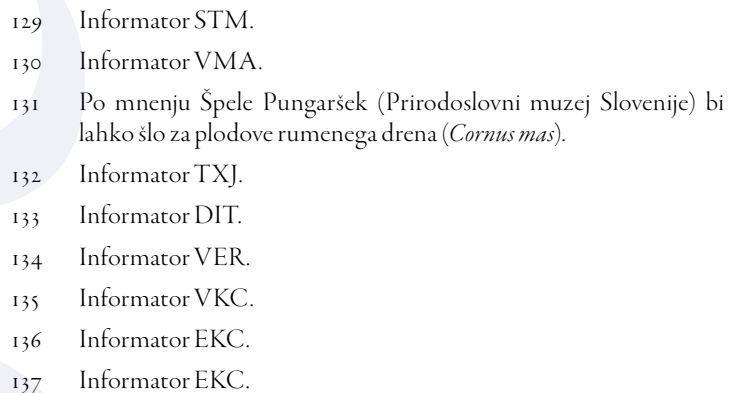

\section{$\mathrm{Na}$ brižanskem je bil samo en dren proti le- skovški gmajni, kjer je še danes, uporabljali paso ga za izdelavo butaric. ${ }^{138}$}

Izpričana je uporaba njegovega lesa, o uporabi njegovih plodov ne govori skoraj nihče. Za Brege se omenja, da so v Vrbini nabirali plodove neke vrste grmovnice za črnilo in liste za zdravljenje rdečike pri prašičih (Rihter 2010, 30), vendar nam v kasnejših pogovorih, teh rastlin ni uspelo identificirati. Ena od možnosti uporabe za črnilo je izpričana v okolici Trebnjega, kjer so za izdelavo črnila uporabljali črni trn (Papež 20IO, 38 ).

Danes izginula cipresovka $\mathrm{v}$ Vrbini je brin (Juniperus sp. ). Na vihranskem je bilo veliko brinja na pašnikih im. Cesarsko. Nekateri so brinove jagode nabirali in jih dajali $\mathrm{v}$ šnopc, večina pa ga je uporabljala pri dimljenju mesa. ${ }^{\mathrm{I} 9} \mathrm{~V}$ Gorenjeskopiški vrbini:

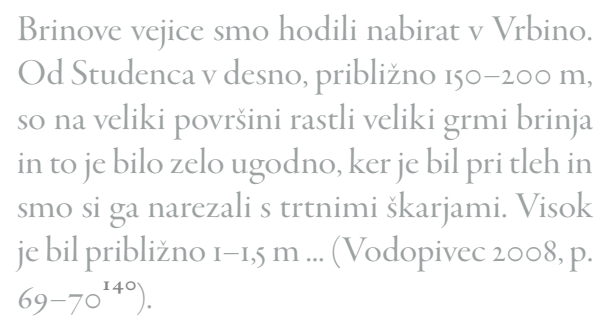

V Brižanski Vrbini je rasel na ledinama Mali in Veliki prudi (Rihter 20ı0, 30). Tako v skopiškem kot v brižanskem primeru je bilo njegovo rastišče v prvi polovici 20. stoletja tam, kjer so bili v 2. četrtini 19. stoletja ali še kasneje, rečne struge še pretočne, a so po savski regulaciji ostale suhe in puste. Kakor ugotavljajo domačini, je brin že v začetku 2. polovice 20. stoletja povsod tod postopoma izginil. Od začimb se na Bregah omenjajo rastišča kimla (kumine) na ledini Stare gmajne. ${ }^{141}$ V zvezi s tem je tod znano, da se kumina pojavlja na ilovnatih tleh, navadno na robovih Krškega polja, npr. ob vznožju Veniš, zato je pričevanje v primeru Starih gmajn zelo pomenljivo. Tam je šlo ob meji z Hančavimi Lastina-

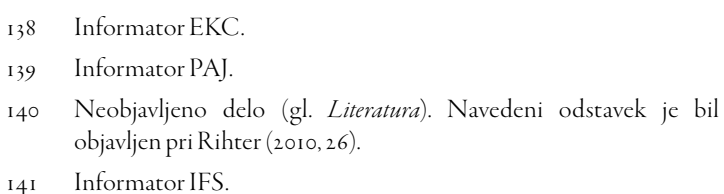


mi za strugo z ilovnato naplavino, $v$ situaciji podobno, kakor je predstavljeno v poglavju Ilovica (gl. tam).

V raziskavi prehrane v 19. stoletju na Slovenskem, Gorazda Makaroviča, najdemo številne vzporednice z zgornjimi podatki in tudi prepletanje istih rastlinskih vrst tako $\mathrm{v}$ ljudski prehrani kakor tudi pri živalski krmi (prim. Makarovič 1991, I6I-163). Prav tako sta tozadevno izpovedni raziskavi Borisa Kuharja iz srede 20. stoletja z območja Škocjana na Dolenjskem (Kuhar 1972) in Vilka Novaka (1947) za območje Prekmurja. Slednji je izpostavil tudi pomen zbiralnega/nabiralnega gospodarstva tako z etnološkega (Novak 1957, 19-20) kot tudi gospodarskega vidika in nekatera $s$ tem povezana raziskovalna vprašanja (Novak 1957, 27). Vlasta Mlakar prinaša pregled tradicionalnih znanj o uporabi rastlin na Slovenskem (2015), kjer najdemo našim podobne ter številne druge primere uporabe rastlin.

\section{Zdravilne rastline}

Brižani so kot zdravilno rastlino cenili polaj ali polajc (iz nem. polei za Mentha pulegium), ki je rasla na gmajni Pod vrbami, nekoliko višje nad tam zastajajočo vodo, za razliko od sička (gl. Druge ...), ki je tam rasel neposredno ob vodi. Polajc je dišal kot meta in ji je bil tudi podoben, cvetel pa je modro. ${ }^{142} \mathrm{Na}$ Drnovem so ga imenovali polaj in so ga nabirali na območju Gmajne na predelih v stari strugi. ${ }^{\text {I43 }} \mathrm{Na}$ Bregah: Jedli smo / ... /, če si bil bolan pa polajc z jajci. ${ }^{144} \mathrm{Ra}$ stlino so osmukali in pekli z jajci, zato so pravili tudi: Polajc pa devet jajc! Ali pa: En poljac pa deset jajc! ${ }^{145}$ Nekateri razlagajo pretirano količino jajc s tem, da se je šele tako lahko pojedlo sicer zelo grenak polajc, ki so ga uporabljali tudi proti driski. ${ }^{146}$ Drugi pravijo, da je pomagal pri prehladu in za pljučne bolezni. ${ }^{147}$ Zvočno podob-

I42 Informator VER.
I43 Informator EDA.
I44 Informator EKC.
I45 Informatorji VKC, VER, EKC in IFS. Obstaja več variant o številu
jajc.
I46 Informator IFS.
I47 Informator EKC.

no ime za neko zelišče imenovano pelajc se pojavlja nedaleč od tod, v Gorjancih, in sicer v vaseh okoli Orehovca, kjer so poznali »čaj za moške iz »moškona«, »pelajca «, ki naj bi pomagal tudi pri prehladu. «(Sosič 2000, 243).

A že v sosednjih Mrtvicah so nekateri imeli istoimensko, vendar očitno ne enako rastlino, polajc, za t. i. grdo rastlino, ki naj bi povzročala glavobol. Nekateri so jo uporabljali kot repelent, za žvadi tikute ${ }^{\mathrm{r} 48}$ odganjati. Na Mrtvicah ga je bilo največ na Gmajni, a se je do danes zatrl. ${ }^{\text {I9 }}$ $\mathrm{Na}$ Mrtvicah verjetno ni šlo za isto rastlino kot na Bregah, čeprav ju po ljudskem spominu druži isto ime. Izginotje te rastline v brižanski vrbini domačini povezujejo s savsko regulacijo in posledičnim padcem talne vode.

$\mathrm{Na}$ brižanskem spodnjem polju so poznali na pustih tleh rumeno deteljico, ki so jo nabirali za zdravilni čaj, ${ }^{\text {I5o }}$ cvetela je med prvimi cvetlicami že konec aprila na ledini Pliš-Zaroman ${ }^{\text {I5I }}$ in na ledini Remen. ${ }^{152}$ Po vojni so jo nabirali in sušili za farmacijo. ${ }^{153}$ Rasla je tudi na ledini Flančišče in povsod na ubožanih travnikih. ${ }^{154}$ Poznali so tudi belo deteljico, ki je imela »bel, resast cvet $\ll$ za katero so pravili, da je za »en čaj ${ }^{15}$. 5 Špela Pungaršek (Prirodoslovni muzej Slovenije), domneva, da bi lahko šlo v prvem primeru najverjetneje za hmeljno meteljko - Medicago lupulina ali pa za poljsko deteljo - Trifolium campestre), $\mathrm{v}$ drugem pa najverjetneje za plazečo deteljo - Trifolium repens (Pungaršek, Š., osebna komunikacija 6. 5. 2016).

Tavžentrože (Centaurium Hill sp. ) so na brižanskem rasle na slabi zemlji severno od Zarbenic in do reke Save. ${ }^{156}$ Prav tako na Zaromanih tam, kjer so bila tla pusta. Bile so priljubljeno

\footnotetext{
I48 Informator KHR. Tikut v pomenu tekut in źvand ali źvad, ki na Krškem polju pomeni domačo perjad, še zlasti kokoši. Npr. žvausko meso, v pomenu kurje meso.

I49 Informator KHR.

I50 Informator VER. Informator ne pomni v kakšne namene.

I5 I Informator IFS

I52 Informator EKC

153 Informatorja IFS in VKC.

I54 Informator VER. Ubožani travniki so slaborodni travniki.

I55 Informator VER

I56 Informator EKC
} 
zdravilo moških za želodčne težave. ${ }^{157}$ Vihrani so nabirali tavžentrožo na ledini Cesarsko in na ledini Toplica. ${ }^{158} \mathrm{Na}$ skopiškem so rastle po pašnikih, kjer so ostajale za kravami, ki so jih zaradi grenkobe puščale. ${ }^{159} \mathrm{Na}$ Drnovem so hodili po tavžentrožo (Centaurium sp. ) na Barovno, ${ }^{160}$ drugi pa na t. i. Vrbinske travnike, t. j. v Remen in Zaroman. ${ }^{61}$ Namakali so jo v žganju, uporabljali pa za obkladke in masiranje, sušili za čaj ali pa jo nosili prišito v rob površnika, da jih je varovala pred uroki. Če je bilo tavžentrože kako leto malo, so nabirali tudi rumeno cvetočo grenčico (Blackstonia perfoliata), ki je bila zastopana $\mathrm{z}$ dvema podvrstama, obe sta uspevali na drnovskih travnikih stare savske struge. Njuna grenčina, je pomagala pri umirjanju razdraženega želodca (Sonja Budna, osebna komunikacija 23. I1. 2016). Že leta I85 I je Valentin Plemel grenčico, tedaj imenovano Chlora perfoliata (Sonja Budna, osebna komunikacija 23. II. 2016), nabiral na mokrih travnikih v stari savski strugi pod Drnovim - kakor je izpostavil - le lučaj proč od rimskodobnih ruševin (Plemel I862, I28), ${ }^{162}$ najverjetneje na ledini Mala barovna.

$\mathrm{Na}$ dolenjeskopiškem, na ledini Marof je rasla arnika (Arnica montana). ${ }^{163}$ Iz šentjanževke (Hypericum perforatum) so na Bregah napravljali šentjanževo olje, ki so ga dali na sonce, da je rdeče ratalo. ${ }^{164}$ Šentjanževka je rasla na koncih njiv, kjer je bila stara savska brežina, npr. na ledini Stari tramleki. Tam, skonca je bilo vsesorte rož. ${ }^{165}$

$\mathrm{Na}$ Drnovem so nabirali materino dušico na drnovskih Flančiščih ob robu ledine Barovna. Pri nekaterih hišah so jo, poleg siceršnje rabe za zdravljenje prehladov, s posebno recepturo uporabljali tudi za umiritev driske. ${ }^{166}$ Glog so nabi-

$\begin{array}{ll}157 & \text { Informator VER. } \\ 158 & \text { Informator CAR. } \\ 159 & \text { Informator RCD. } \\ 160 & \text { Informator BAS. } \\ 161 & \text { To pomeni na območje vasi Brege, na predel Remen in Zaroman. } \\ 162 & \text { Za ta podatek sem hvaležen Sonji Budna. } \\ 163 & \text { Informator SUT. } \\ 164 & \text { Informator VER. } \\ 165 & \text { Informator VER. } \\ 166 & \text { Informator TTR. }\end{array}$

rali v času cveta za probleme s pritiskom. ${ }^{167} \mathrm{Za}$ domače zdravljenje so Drnovci v Vrbini nabirali »češmigono « (češmin) in »babji zob (šipek) ter lipove cvetove (Tilia sp. ) (Rihter 2010, 30). Pri neki hiši na Drnovem so po obnovi med vojno požgane domačije pastirjem naročili, naj jim prineso iz Vrbine mlado lipo, da bo hiši v okras, za senco in za čaj. ${ }^{168} \mathrm{Ob}$ poteh, na suhem je rasel rmanc (rman; (Achillea sp. ), ki so ga uporabljali za čaj in za zdravljenje razpokanih nog ${ }^{169}$ ter kot nujno sestavino piče za mlade račke. ${ }^{170} \mathrm{Na}$ pašniku Barovna so nabirali tudi gladeš (Ononis sp. ) in ga uporabljali za odvajanje vode iz telesa ${ }^{171}$ in za lajšanje težav z ledvičnimi kamni. ${ }^{172}$ Brižani so ga na Gmajnah kosili skupaj z ostalim travinjem za steljo, ker ga živina ni marala (gl. Stelja). ${ }^{173}$ Vihrani pa so njegove korenine uporabljali za zdravljenje konj in ledvičnih kamnov, nabirali pa so ga na ledini Cesarsko. ${ }^{174}$

$\mathrm{Na}$ Mrtvicah so v Vrbini, ob poteh, na pustih tleh nabirali vratič (Tanacetum vulgare). Uporabljali so ga za zdravljenje živine, kadar jo je napihovalo. Nabirali so ga na ledini Prudi severno od Starih vačk. ${ }^{175}$ Vratič so na D. Skopicah sušili in kobilam dajali med oves, za boljše odvajanje blata in za siceršnje zdravje. ${ }^{176}$ Iz Drnovega je znan podatek o nekdanji uporabi vratiča za mehansko razširjanje materničnega vratu za sprožitev prekinitve nosečnosti (Sonja Budna, osebna komunikacija, 26. II. 20I6). Na Bregah so vratič uporabljali za teleta, če so imela drisko. Iz cvetov so kuhali čaj. Nekateri ga imajo tu sedaj za okras v vrtu, nekdaj pa so bila njegova rastišča ob brežinah, kjer niso kosili ter ob grmovju in ob po-

$\begin{array}{ll}\text { I67 } & \text { Informator EDA. } \\ \text { 168 } & \text { Informator TTR. } \\ 169 & \text { Informator TTR. } \\ \text { I70 } & \text { Informatorja MIM in VER. } \\ \text { I7I } & \text { Informator VVK. } \\ \text { I72 } & \text { Informator PLO. } \\ \text { I73 } & \text { Informator VKC. } \\ \text { I74 } & \text { Informator PAT. } \\ \text { I75 } & \text { Informator KHR. } \\ \text { I76 } & \text { Informator RCD. }\end{array}$


teh. ${ }^{177} \mathrm{Na}$ Vihrah so ga uporabljali proti driski za prašiče in za živino. ${ }^{178}$

Kot mažo so na Mrtvicah pripravljali gabezove korenine, ki so jih prepražili na maščobi. ${ }^{179}$ $\mathrm{Na}$ Drnovem so gabezovo mast (iz gabezovih korenin) uporabljali za težko celeče se rane, ozebline in preležanine (Sonja Budna, osebna komunikacija, 26. II. 2016).

Za bolezni srca so Mrtvičani nabirali glog in trnulo ali trnuluc (črni trn), ki je rasel na (mrtviški) Barovni, Drašcah in na Prudih. ${ }^{180}$ Glog so uporabljali za zdravljenje težav povezanih s srcem, kuhali pa so ga v čaju. Nabirali so tudi šipek, ki so mu tam pravili divja gajtroža. ${ }^{181}$ Iz čičmigone (češmin) so po vojni delali tudi kis. Gladeš so kopali za zdravila na ledinah Stara vačka in Prud. ${ }^{182} \mathrm{Na}$ Bregah je na predelu Gmajna rasel na več mestih (gl. Stelja). ${ }^{183} \mathrm{Za}$ drisko so na Mrtvicah nabrali hrastovo lubje. ${ }^{184}$ Podobno so tudi na Vihrah zdravili drisko svinj s hrastovim lubjem. ${ }^{185}$ Sladke koreninice so na Vihrah rasle na ledini Pod belim bregom. ${ }^{186} \mathrm{Na}$ brižanskih pašnikih je rastel tudi bodeč kačji stric, kot pravijo, dveh vrst, in sicer visok, ki je cvetel rdeče ter nizki z belim cvetom, ki je kazal vreme.

\section{Rastlinje za okras}

$\mathrm{V}$ veselje in za okras so predvsem pastirice v 1930tih letih na brižanskem, nabirale različne rože, predvsem je izpričano veselje do nabiranja orhidej, ki jih opisujejo takole: V Zaromanih na Pliši so rasle kukavice/kukuce, imenovali so jih tudi petelinčki (Ophrys sp. ). Najprej so nabirali modrellila (Orchis morio), za tem pa še mačja očesa, ki so jim pravili tudi račke (Ophrys sp. ). Ko so prve kukavice odcvetele, so pričele cveteti več-

177 Informator VER.

178 Informator CAR.

179 Informator XMR, KHR.

180 Informator XMR.

I8I Informator KHR.

I82 Informator KHR.

183 Informator VER.

I84 Informator KHR.

I85 Informator CAR.

I86 Informator CAR. je kukavice z roza cvetovi (Ophrys sp. ). ${ }^{187}$ Raslo je več vrst kukuc, različnih barv, visoke ali nizke in kakor ugotavljajo - so do danes številna njihova rastišča uničena $\mathrm{z}$ sodobnimi kmetijskimi praksami. Okoli Remena in pri Žabljeku so v maju rasli visoki večcvetni zvončki. ${ }^{188}$ Spomladi so kukavice rasle po celotnem Remenu, sedaj, kot pravijo, le še v Podmališču. ${ }^{189}$ Rasle pa so na območju Remena, kot pravijo, tudi velikonočnicam podobne rože. ${ }^{190}$ Najverjetneje je šlo za isto vrsto, kot na ledini pri Dolgem grmu na drnovskem polju, kjer je izpričano nabiranje $z a$ spank $^{191}$ (Pulsatilla nigricans), ki so jim na Drnovem pravili fajfe. ${ }^{192}$

\section{Od Borovnic navzdol so travniki im. So- višče (Savišče), ki se stegajo na mrtviško in prav tam je največ podleskov. ${ }^{193}$}

Neznanokje na brižanskem so nabirali tudi encijanček ali bobke, kot so pravili encijanu ${ }^{194}$ (Gentianasp.).

$\mathrm{Na}$ bogatstvo in številčnost orhidej in drùgih rastlin na ubožanih travnikih ob Savi, kot jim pravijo nekateri domačini, in na pomen tega habitata v svetovnem merilu, je že pred leti opozoril Dušan Klenovšek (200I, II).

\section{Rastlinje za velikonočne in kresne šege} ter druge navade

Rastlinje, ki se je uporabljalo za velikonočne in kresne šege so nabirali skoraj izključno v poplavni ravnici. Tam so razen redkih izjem dobili vse potrebne sestavine.

$\mathrm{V}$ okviru predvelikonočnega obredja so ponekod v G. Skopicah za butaro za cvetno nedeljo $\mathrm{v}$ Vrbini iskali vrbove veje, bezeg in bršljan ( $\mathrm{He}$ dera helix). ${ }^{195}$ Tudi v vasi Brege so za butaro do-

$\begin{array}{ll}187 & \text { Informator EKC. } \\ 188 & \text { Informator EKC. Zaenkrat nedoločljiva vrsta. } \\ 189 & \text { Informator VKC. } \\ 190 & \text { Informator EKC. } \\ 191 & \text { Informator VKC. } \\ 192 & \text { Informator MIM. } \\ 193 & \text { Informator VKC. } \\ 194 & \text { Informator EKC. } \\ 195 & \text { Informator STM. }\end{array}$


bili večino sestavin v Vrbini. V butarici je moralo biti s leskovih šib, brin (gl. Hrana za ljudi...), bezeg in dren, vrh pa je bil ovit z žingrcem (zimzelen, Vinica sp. ). Brižani so pred cvetno nedeljo obiskovali tam edini, stari dren v bližini Save

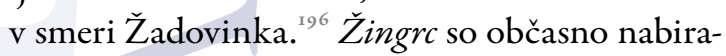
li tudi izven območja naše raziskave v Venišah, ${ }^{197}$ skonca Strgarjevega (izven karte na Sl. I), ${ }^{198}$ še zlasti ob žegnanjskih nedeljah in ob božjih poteh, ko so z njim okrasili vozove. ${ }^{199}$ Gorenji Skopičani so žingarc nabirali v pustih grmovjih na ledini Flančišče. ${ }^{200}$

Ponekod na Mrtvicah so butarco sestavljali iz bršljana, leske, dobroletine (Viburnum lantana), gabra (Carpinus sp. ), žingarca, farone in oljke. Pri opisih farone gre po mnenju Špele Pungaršek (Prirodoslovni muzej Slovenije) za navadno trdolesko - Euonymus europaeus (Pungaršek, Š., osebna komunikacija, 6. 5. 2016). Žingarc ali zimzelen je prej rasel na več mestih v bližini stoječih voda. Tako so ga Mrtvičani nabirali Pod belim bregom pri Vihrah, kjer ga je bilo še posebej veliko. ${ }^{201}$ Razen oljke, so vse sestavine našli v Vrbini, celo gaber. Zanj so npr. verjeli tudi, da varuje pred strelo. Zgolj za primerjavo in vtis navedimo, da Drnovci v okviru svojega spodnjega polja, ki je bilo tedaj že relativno suho, za butarico v njem niso našli vseh potrebnih rastlin, zato so jih iskali tudi drugod. Tako so žingrc nabirali v oddaljenem Trnovcu (izven karte na Sl. I), kakor so Drnovci imenovali konec doline potoka Žlapovec, tik pred njegovim nekdanjim izlivom v Savo v Krškem.

V G. Skopicah naj bi vsak pastir večer pred kresom (poletni solsticij) v Vrbini nalomil veje belega topola (Populus alba) in nabral šentjanževe rože: »Napravili so se šopi, da se je lažje nosi-

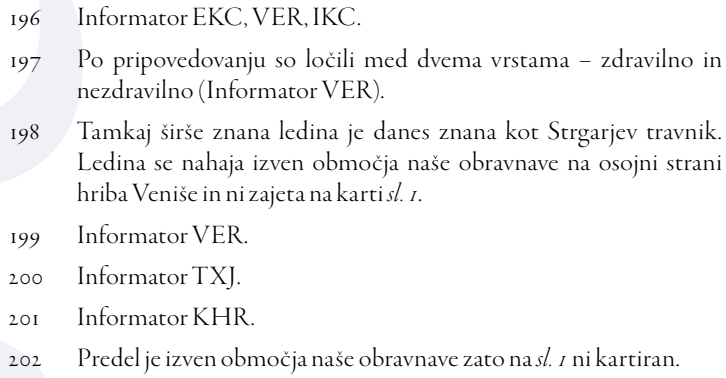

Predel je izven območja naše obravnave zato na sl. I ni kartiran.

lo domov. Veje so doma vstavljali za tesane stebre v plotu ob glavni vaški cesti. Iz šentjanževih rož pa smo vrh lat naredili preplet. In tako cela vas. Po treh dneh se je ves okras vrgel na domači gnoj. $\ll^{203}$ Isti običaj je izpričan tudi v vasi Brege, kjer so morali na predvečer kresa pastirji prinesti domov še pred sončnim zahodom rastlinje za krašenje vaških plotov.

Rož smo nabrali za polne naročaje - rume-
ne in bele kresne rože, ni bilo pravih kresnic,
pobrali smo vse kar je takrat cvetelo. Krasi-
li smo po plotih med latami, na stebre smo
pa šopke dajali in okrasili smo tudi krave, ki
smo jim rože napletli med rogove. ${ }^{204}$

$\mathrm{Na}$ plotove so napletali kresnice; nekateri so jih dajali le na stebre, drugi so iz njih napravljali preplete. Nekateri so ločili med $\gg$ belo $\ll$ in $\gg r u-$ meno kresnico «, obe pa so nabirali na ledini Remen in Gmajna. ${ }^{205}$ Nekateri pravijo, da je šlo v teh primerih za rože vrste lakota ${ }^{206}$ (Galium sp. ). Tudi na Drnovem so ob kresu krasili plotove $\mathrm{z}$ rastlinjem, ${ }^{207}$ vendar se potankosti o poteku niso ohranile. Vemo pa, da so drnovski koledniki sv. Jurija nalomili vrbove vejice za Savo, ki so jo po tem polagali na okna hišs. ${ }^{208}$

Količino paše so na Drnovem napovedovali po neki, $v$ času po kresu belo cvetoči in asparagusu podobni roži, na peščenih tleh pašnika Barovna. ${ }^{209} \mathrm{Na}$ brižanskih pašnikih so po bodeči neži (Carlina acaulis) napovedovali vreme.

Kurjenje ognja - kresovanje $\mathrm{v}$ času kresa (poletni solsticij) je bilo tesno povezano $s$ poplavno ravnico polja. Na Drnovem se je izvajalo na ledini Barovna, ${ }^{210}$ na Bregah v savski brežini pod vaško kapelico pri ledini Traminčki, ${ }^{211}$
203 Informator STM
204 Informator EKC.
205 Informator IFS
206 Informator EKC.
207 Informator VVK
208 Informator EDA
209 Informator TTR
210 Informator SVD, SJR, idr.
21 I Informator RVA, RVL. 
na Mrtvicah na ledini Barovna. ${ }^{212}$ Mesto kresa na Gorenjih Skopicah pa poleg ljudskega spomina izdaja kar toponim sam - Kresi, severno za t. i. Luznarjevo kapelico. ${ }^{213}$

\section{Druge uporabne rastline}

Brižani so poznali na močvirnih in vlažnih območjih tudi rastlino, ki so jo imenovali sić, ${ }^{214}$ $s_{i c ̌ k}^{215}$ ali sičjak ${ }^{216}$, rasel je pri ledini Globajnk s stalno vodo ${ }^{217}$ in pod Vrti, na ledini Pod vrbami pri Gmajni in v Ločici, ${ }^{218}$ kjer je zastajala voda. ${ }^{219}$ Kot zanimivost omenimo, da je na območju brižanskega spodnjega polja znana tudi ledina Sičjaki. Ime je izpričano za njive že na franciscejskem katastru leta 1824 , kot Sitschenyaki. ${ }^{220}$ Sičk, je bil zlasti cenjen med otroki - pastirji, zaradi dobrih lastnosti za vezavo in za pletenje. Rasel je na močvirnih predelih. Na paši so ga uporabljali za izdelavo igrač, pa tudi sicer. Pletli so iz njega izdelke za igro, kot so košarice, reziraparate in klobuke ter številne druge izdelke. ${ }^{22 x}$ $\mathrm{Na}$ Brižanskem - ugotavljajo domačini - danes ni več sička. Na podlagi vzorčnih stebel sička, ki jih je iz drugega rastišča priskrbela Elka Grilc iz Sevnice, je Špela Pungaršek (Prirodoslovni muzej Slovenije), ugotovila, da gre najverjetneje za sivozeleni loček (Juncus inflexus) (Pungaršek, Š., osebna komunikacija, IO. 5. 2016 in I. 7. 2016). $\mathrm{V}$ poplavni ravnici reke Sotle so sivozeleni loček imenovali šar (Kolbezen in Žagar 1978, 177). $\mathrm{V}$ zvezi z otroško igro in pletenjem igral se tam omenja tudi sitje, kot visokorasla trava ob Sotli (Počkar 1998, I05).

$\mathrm{Na}$ Bregah so poznali na mokrih tleh tudi rastlino im. flošc, $\gg$ visoko, ostro in grobo, sivo tra-

$\begin{array}{ll}212 & \text { Informator KHR. } \\ 213 & \text { Informator STM. } \\ 214 & \text { Informator EKC. } \\ 215 & \text { Informatorja EKC in VER. } \\ 216 & \text { Informator VKC. } \\ 217 & \text { Informator VKC. } \\ 218 & \text { Informator IFS. } \\ 219 & \text { Informator VER. } \\ 220 & \text { Glej franciscejski kataster za k. o. Drnovo - grafični del (mapni list } \\ & \text { VI) (gl. Literatura). } \\ 221 & \text { Informator EKC. }\end{array}$

vo, $\mathrm{z}$ večkrat preščipnjenim/zavitim steblom «. ${ }^{222}$ To so prinesli domov, jo poravnali v šop, ki so ga v dlani ovili v krog premera okoli $20 \mathrm{~cm}$ ter ga stisnili skupaj. Takšna priprava je nadomeščala krtače za ribanje tal. Bila je zelo trpežna, vendar zaradi grobosti za roke zelo neprijetna. ${ }^{223}$

O domači izdelavi krtač poroča Elka Grilc:

»sirkove krtače za ribanje tal. Iz nekih trav
je poiskal korenine, ki so bile bolj tanke, dalj-
še in rahlo kodraste. Te korenine je opral,
lepo zložil in namakal v vodi, da se niso po-
sušile. Iz teh korenin je naredil krtače, po-
dobne tistim, ki so jih prodajali in smo z nji-
mi ribali tla v hiši.

Šlo naj bi za korenine neke trave, ki je rasla na starih travnikih:

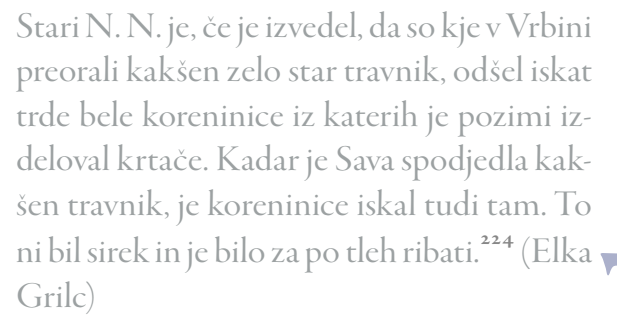

Poznali pa so tudi »temnosivo, tanko in ostro travo «, ki je na brižanskem v 30 -ih letih 2o. stoletja rasla le še na manjšem, mokrem odseku remenske struge na predelu Delečki. Ta »trava $\ll$ zaradi redkosti njenih rastišč ni bila več del splošno razširjene uporabe, ljudje pa so do danes pozabili njeno pravo ime. Zanjo pomnijo, da so jo generacijo starejši prebivalci z Breg še uporabljali za polnjenje štrozakov (ležišč) in komatov. Krave je namreč niso marale. Cenjena lastnost je bila ta, da se po sušenju ni sprijemala in je bila enakomerne sive barve. ${ }^{25}$ Domala ista uporaba je zabeležena v bližnji Kostanjevici na Krki za neko močvirsko rastlino, ki so jo tam imenovali plaščnka. Šlo je za manj kot meter visoko »travo«, ki so jo želi v gozdu in sušili, z njo pa polnili komate. Ker je bila čista in brez zeli so jo upo-
222 Informator VER, IFS
223 Informator VER, IFS
224 InformatorjaVER, IFS.
225 Informator VER 
rabljali tudi za polnjenje žimnic (Zakšek 2OI2, 30) in za izdelavo pastirskih plaščev, kakršne so nosili v tamkajšnji okolici (Makarovič 1960, 202; Mlakar 20I5, 65). Po mnenju Sonje Budna, gre za migalični šaš (Carex brizoides $\mathrm{L}$. ), ki so ga $\mathrm{v}$ Zakrakovju (izven karte na Sl. I) imenovali plaščenka ali tudi pleščinka, zanj pa so vedeli tudi na Drnovem (Budna, S., osebna komunikacija 6. ı.. 2016).

Franc Lovrenčak, v opisu prsti in rastja poplavenga sveta ob reki Krki ugotavlja, da tamkajšnje higrofilne rastlinske vrste, zlasti tiste iz rodu ločkov (Juncus. Sp. ), nimajo hranilnih lastnosti, travniki kjer rastejo pa naj bi imeli neznaten gospodarski pomen (Lovrenčak 1980, I40).

Zgoraj našteta pričevanja s Krškega polja, npr. da krave teh močvirnih trav niso marale ter opisi njihovih lastnosti, da se po sušenju niso sprijemale in so ohranjale barvo, sama po sebi govorijo o njihovi povsem drugačni, nekrmni uporabi. Pomen teh trav, torej vsaj za starejša obdobja, ne moremo videti skozi gospodarsko vlogo travnika kot takega. Zgoraj izpričani načini uporabe omenjenih trav, še v I. polovici 20 . stoletja, govorijo o drugačnih vrednostih tovrstnih travnikov, ki jih ni moč razumeti v današnji luči intenzivne izrabe.

\section{Nabiranje in uporaba drobnih živali}

$\mathrm{Na}$ paši v Vrbini so pastirji iskali čričkove rokav$c^{2} k e^{226}$ ali srajčke $e^{227}$, kakor so pravili pajčevinastim oblogam $\mathrm{v}$ rovčkih, ki so jih uporabljali za zdravljenje ran. Kot pripoveduje Elka Grilc, so rokavcke ali srajcke zbirali in jih imeli vedno tudi doma na zalogi za zdravljenje ran vseh vrst. Čakali so pred luknjo, dokler živalica ni prišla ven, nato pa so jo hitro odstranili, da ni mogla nazaj v luknjo. Živalica je bila hitra, obnašala pa se je zelo previdno. Segli so s prstom v luknjo in ven potegnili rokavček. Ti so bili dolgi približno Io $\mathrm{cm}$ in spodaj okroglo zaprti, kot naprstniki. Zunanja stran je bila blatna in prašna, znotraj pa gladka »kot pajčevina«. Notranjo stran so dajali na rane za zašcito in za obsušitev ter za boljše

\section{Informator EKC.}

227 Informator VER celjenje. $\ll^{228} \gg$ Pajčevino v zemljii $\ll$ so za celjenje ran kopali tudi na Drnovem in tamkajšnjih pašnikih. ${ }^{229}$

Po mnenju Tomija Trilarja (Prirodoslovni muzej Slovenije) ni šlo niti za črička (ta ne koplje lukenj) in niti za poljskega murna (ta koplje luknje, vendar nima predilnih žlez), s katerim bi utegnili zamenjati črička, temveč verjetno za pajka tapetarja ali vrečkarja iz rodu Atypus. Ta živi v kolonijah na travnikih in si izkoplje rov v zemljo, ki ga okrog in okrog obloži z mrežo im. »svilena vrečka«. O tem verjetno govori tudi potankost v zgornji navedbi, da so pred luknjo $\gg$ čakali « in ne $\gg$ bezali $\ll$ kakor pri murnih. Namreč v kolikor bi vanjo drezali, bi se pajek vanjo le še bolj odmaknil (Trilar, T., osebna komunikacija, 20. -21. 4. 2016).

O zdravilnih učinkih pajčevine je mnogo poročil. Krškopoljski identična uporaba »svilenih vrečk« pajkov vrste Atypus, za zdravljenje ran je izpričana v Južnih Karpatih (Wright in Goodacre 20I2, in tam navedena literatura). V Sloveniji je uporaba pajčevine etnološko izpričana predvsem za namene zdravljenja ran na koži; ureznin, oteklin in ustavljanja krvavitev (Sosič 2000, 224, 228, 231-232, 236 in 239). Ponekod na Dolenjskem za zdravljenje ran in zaustavljanje krvavenja navajajo pajčevino, ki so jo imenovali »marijini štumfki« (Sosić 2000, 217 in 244), na območju Kobarida pa »Matere Božje nogavice« (Sosić 2000, 233) ali v okolici Cerknega - »bohkove hlačce« (Sosić 2000, 240). V enem primeru z Dolenjske je razvidno, da je pajčevina izvirala tudi z neke rože (Sosić 2000, 217).

Vihrani so izvajali s pomočjo pijavk, ki so jih nabirali na ledini Spina/Struga tudi zdravljenje:

To so govorili stari ljudje. So šli in vzeli pijavko in če je imel vnetje zoba ali če se je vnela korenina, so si dali gor pijavko, da se je prisesala in bolno kri potegnila ven. To so počeli tukaj in še ne tako dolgo nazaj, so govorili. In enako tudi, če si imel kakšen tvor. ${ }^{230}$

228 Informator EKC

229 Informator BAS.

230 Informator PAT. 
Tudi na Bregah je bilo razširjeno zdravljenje s pijavkami. Izvajali so ga pri ljudeh s slabo prekrvavljenimi in nasploh slabotnimi nogami.

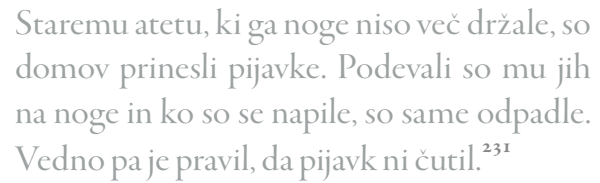

Na Skopiškem:

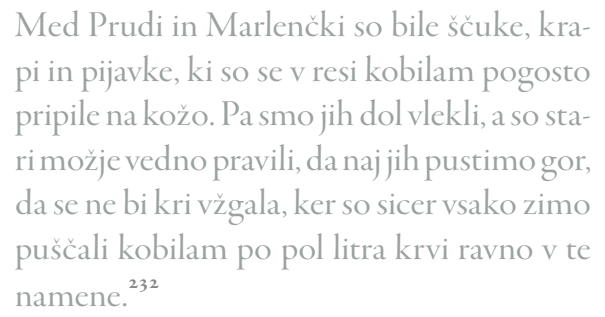

Stari ate, ki je bil rojen leta 1887 je pripovedoval, da so se na gorenjeskopiškem na predelu mrtvice Zlatič, zdravili s pijavkami na mestu samem. Pijavk je moralo biti na obolelih mestih ravno pravšnje število, kot so govorili stari možje. ${ }^{233}$

Nabiranje in raba zdravilnih rastlin ter pijavk na Krškem polju ima dobre primerjave v pregledu gradiva o ljudski medicini, ki so ga zbrale terenske ekipe SEM med 1948-1984 v Sloveniji (Sosič 2000). V obravnavanemu primerljivem okolju, kakršno je pokrajina ob Muri, najdemo našim zelo podobna poročila o ljudski medicini s pijavkami in rastlinami (Zadravec 1985, 130-131), naprimer pri zobobolu, krčnih žilah in ranah na nogah (Zadravec 2000, 59).

$\mathrm{Na}$ Bregah so ob stoječi vodi pri Pod vrbah in na vzhodnem delu Gmajn, na rastlinah, ki so jih imenovali »rdeči mlečki« nabirali velike pisane gosenice raznolikih barv $\mathrm{z} \gg$ rožičkom $\ll{ }^{234}$. Pripovedovalci pravijo, da je rumeno-rdeče cvetje delovalo dekorativno in kot se je zdelo, je vsak cvet imel svojo gosenico, ki so jim pravili tudi konjički. Vsaka gosenica je bila drugačna, vsaka lep$\check{s} a$. Opazovali so jih leže ${ }^{235}$ ali pa jih nosili domov,

$$
\begin{array}{cl}
231 & \text { Informator VER. } \\
232 & \text { Informator RCD. } \\
233 & \text { Informator TXJ. } \\
234 & \text { Informator VER. } \\
235 & \text { Informator EKC. }
\end{array}
$$

kjer so jih starejši družinski člani uporabljali za napovedovanje letine (česa bo več) in poteka zorenja žita, za kar sta govorili njihova barva in okras oz. pisanost. V zgodnjem poletju, $\mathrm{v}$ času pred žetvijo ječmena in pšenice, so bili pozorni na gosenice, na katerih je prevladovala rumena barva. Ker pa so za pšenico in ječmenom, včasih še tudi za ovsom, v poznem poletju sejali ajdo, so tedaj iskali takšne gosenice (iste vrste), ki so omogočale napoved količine ajdove moke. Zato so sedaj posvečali pozornost tistim, ki so imele več rjavkaste ali črne barve v podlagi. Črna barva ajdovih luščin je namreč pomenila več moke, rjava pa manj namlete moke. ${ }^{236}$ Tudi na Drnovem so na paši iskali gosenice s pikami in jih nosili kazati domov. Največ jih je bilo na pašniku Barovna. Posamičen vzorec je simboliziral določeno žito. ${ }^{237}$

Po mnenju Tomija Trilarja (Prirodoslovni muzej Slovenije) je verjetno šlo za gosenice navadnega mlečkarja (Hyles euphorbiae), ki se prehranjujejo na mlečkih (Euphorbia sp. ) (Trilar, T., osebna komunikacija, 20.-2I. 4. 2016).

Že pred drugo svetovno vojno so v Brežicah odkupovali polže, ki so jih v brižanski Vrbini v te namene tudi nabirali. ${ }^{238}$ Polži so se za prodajo tod nabirali še v 80 -ih letih 20. stoletja. Sicer pa so jih pred tem pekli tudi na paši.

\section{Lov}

$\mathrm{V}$ poplavni ravnici je bila številčna tudi divjad, ki je bila sestavni del občasnega jedilnika. Visoke divjadi pred drugo svetovno vojno tod še ni bilo ali pa je bila zgolj prehodna. Polje je še daleč v drugo polovico 20 . stoletja slovelo predvsem po zajcih in poljskih kurah; fazanih, jerebicah in prepelicah, pri čemer slednji vrsti od 1960-tih nista več lovni. Že Valvasor omenja na Krškem polju prisotnost velikega števila jerebic v povezavi s kulturno pokrajino in tudi njihov lov (Vlavasor 2010,246 in 248). Lov je bil pred povojno ustanovitvijo lovskih družin Krško in Cerklje ob Krki, predmet različnih zakupnikov (prim.

236 Informator VER, EKC in IFS

237 Informator BAS.

238 Informator EKC.

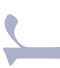

\section{O} (n) (n) 
Šribar 2018, 123-125). V 1930-tih so npr. na drnovsko spodnje polje zahajali zagrebški lovci, ki so bili v zimskem času nastanjeni na Drnovem. ${ }^{239}$ $\mathrm{V}$ okviru obravnavanega območja, njegovih naravnih danosti in $\mathrm{v}$ zvezi $\mathrm{z}$ Vrbino ter gospodarjenjem $z$ divjo perjadjo, omenimo domačina Franca Škofljanca z Breg, ki je kot vsestransko dejaven $\mathrm{v}$ povojnih letih znatno pripomogel pri vzreji in povečanju staleža jerebic. Nadaljeval je tudi kinološko tradicijo dr. Vilka Pfeiferja iz predvojnega časa, ko je na Bregah leta 1962 ustanovil psarno nemških kratkodlakih ptičarjev $\mathrm{z}$ zvenečim domačim imenom »Vrbinska $\ll$, ki je aktivna še danes (B. T. 201 4, 464).

Povrnimo se obravnavanem času prve polovice 20 . stoletja. T. i. krivolov je bil prisoten predvsem v sebenjkovskih pa tudi v nekaterih kmečkih družinah. Tema je zanimiva in bi zahtevala širšo razpravo, zato se tukaj omejimo le na kratek pregled lovskih dejavnosti brez naprednih lovnih pripomočkov, ki so bile $\mathrm{v}$ domeni pastirjev $\mathrm{v}$ Vrbini. Izjema so le opisi lova s kamni, ki ga opisujemo v odstavku o Prodnikih (gl. Prodniki).

Pastirji predvojnih in tudi povojnih generacij, so spremljali premike različnih divjih živali, zato so lahko pravočasno dostopali do jajc zlasti poljskih kur, od mladičev pa so cenili zlasti golobje, grličje, sračje in vranje, seveda v času njihove največje tolstosti, to je tik pred vzletom. Drobovje so otrebili na kraju samem, meso pa sprali $v$ reki ali v mlaki ${ }^{240}$ ter ga spekli na ognjišču, ki je bilo večinoma stalno, v bližini kakšnega večjega drevesa, npr. vrbe. $Z$ gnezd, večinoma poljskih kur, nabrana jajca so dolenjeskopiški pastirji pekli na ognjišču, ki so ga oblikovali iz blata. V prvem desetletju po vojni so v te namene, pa tudi za peko rib, na območju dolenjeskopiške Spince že uporabljali pleh, navadno pridobljen iz tamkajšnjih letalskih razbitin. ${ }^{241} \mathrm{~K}$ temu spomnimo še na peko polžev, ki smo jih omenili že v poglavju o nabiralništvu (gl. Nabiralništvo). Prehrana z ježi je tod izpričana v času krize

239 Nformator DLJ.

240 Informator TXJ.

24I Infortamtor ZHK. prvih povojnih let, ${ }^{242} \mathrm{v}$ poplavni ravnici, na ledini Pod vrbam pa je izpričana v 1930-tih letih v prehodnih romskih taborih. ${ }^{243}$

Velika biodiverziteta nekdanjega okolja se je odražala v bogastvu živali neposredno ob reki Savi in v ravnici ob njej. Sočasen vpogled dajejo nekatera poročila, ki pričajo o obilju lovno zanimivih živalskih vrst. $\mathrm{Z}$ območja levega brege Save so znani zanimivi opisi lovnih vrst živali Ferdinanda Ripšla iz I880-tih let (2007, I55I58). V Savi je bila v 1930-tih letih do Sevnice npr. še kečiga (KLDB 1937, 239 in 288). Stanje živega sveta $\mathrm{v}$ kasnejšem, poregaulacijskem obdobju in problematiko njegovega dolgoročnega obstoja, prikazujejo številne raziskave (npr. Klenovšek 1999; 2001; 2009; Vogrin, M. in Hudoklin 1993; Hudoklin 1993; 2008).

\section{Lesne surovine}

$\mathrm{Na}$ vihranskem, ${ }^{244}$ brižanskem ${ }^{245}$ in skopiškem za obravnavano obdobje kot pomembne omenjajo različne vrste vrb (Salix sp. ) ter topolov (Populus sp. ), med njimi jagend (Populus nigra, jagned) in topolovko, kakor ljudsko imenujejo beli topol (Populus alba), kjer izpostavljajo njegovo svetleče listje in mehak les. Omenja se tudi hrast dob (Quercus robur), vendar je bil tedaj že redko drevo. Jesenovim drevesom na Vihrah pravijo jesenovc (Fraxinus sp. ), manjši gozdič tam še danes uspeva na območju Petrove škarpe severno od ledine Zgorelo, na Bregah pa ob robu Gmajne in med Delečki. Od drugih listavcev omenjajo še črno (Alnus glutinosa) in belo jelšo, ${ }^{246}$ lipo (Tilia sp. ), murvo (Morus alba in Morus nigra), gacjo ali hacanko (Robinia pseudoacacia) in brest (Ulmus sp. ). ${ }^{247}$ Jelše so bile na skopiškem nekdaj zelo razširjene in kjer jih najdemo še danes. $\mathrm{Na}$ Brižanskem so jelše rasle na ledini Velike vode in na ledini Delečki, kjer je običajno zastajala voda

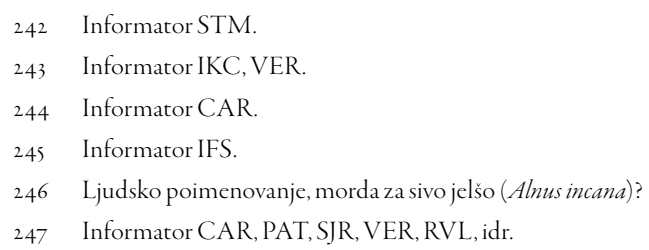


t. i. leskovškega potoka Pašenka. ${ }^{248}$ Jeseni je njegova voda po starih savskih strugah, preko ledine Ločica in Delečki, pritekala vse do zaledja vasi Brege (Rihter 2015, 56 in 262-263). Drnovci so do jelševine prihajali na ledini Zlatičje šele po tem, ko so tam prišli do novih zemljišč v prvi polovici 2o. stoletja. ${ }^{249}$

\section{Grmovnice}

Grmovne vrste so bile zelo razširjene na jarkih in nasipih, ki so omejevali pašnike ter v mejnicah, predvsem pa na pašnikih. Ob poteh v zaledju Breg in Mrtvic so mejnice varovale pred ubegom živine na travnike in na njive. $V$ brižanskih mejnicah spodnjega polja posebej omenjajo vrbo, trnulj (Prunus spinosa), glog (Crataegus sp., tod ljudsko hrušca in redkeje medvedove hruške) ter lesko (Corylus avellana).

Na starih prodiščih - pašnikih (ledini Gorenji prudi in Dolenji prudi) so na skopiškem in brižanskem (Mali in Veliki prudi) kopali za prodajo korenine češmina (Berberis vulgaris) za barvanje tkanin. ${ }^{250} \mathrm{Na}$ skopiškem, vihranskem in brižanskem se omenja nabiranje brinovih jagod in vej (gl. Nabiralništvo). Na Drnovem so vejevje črnega trna za potrebe ograjevanja vrtov in krpanja dotrajanih plotov sekali v mejnicah na spodnjem polju. V zvezi s tem je zanimivo pričevanje o vaški podobi v času druge polovice 20 -ih let in $\mathrm{v}$ tridesetih letih preteklega stoletja:

Planke, malo zagrajeno ali pa iz protja spleten plot in zopet malo zagrajeno/.../ s tem je bilo veliko dela, naš ate - vem, ker smo morali gredo za hišo ograditi - so šli in nasekali tarnula - tarnulavo tarje,25I po tem pa smo s tem pletle ograjo. / ... /, si se takoj nadrl na trnje (Rihter 2015,169-170).

248 Informator EKC

249 Informator BAS

250 Informator VER, IKC, EKC, IFS, STM, idr. Na tem mestu opozarjamo na napako v avtorjevem članku iz leta 2010 (Rihter) na str. 30, kjer bi moralo namesto »kopali korenine jasmina (Rihtzer 2010, 30), pisati »kopali korenine češmina «!

251 Narečno poimenovanje za črni trn (Prunus Spinosa). Tarnulavo tarje, v pomenu trnje črnega trna. Tod razširjeno poimenovanje zanj je tudi darnul, čeravno ne gre za drnulje drena.

\section{Jagned}

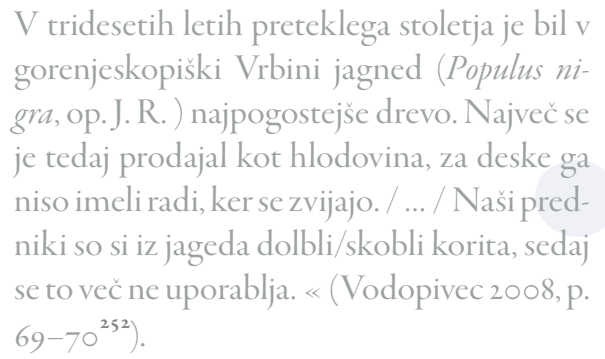

O njegovi nekdanji razširjenosti na vihranskem priča tudi toponim Pod jagnedom, ki je izpričan že leta $1824^{253}$ in je živ še danes v obliki Mali in Veliki podjagend. $\gg$ Iz jagnedovega lesa so na skopiških domovih dolbli korita različnih dimenzij za različne potrebe. « (Vodopivec 2008, p. 69$\left.70^{254}\right)$. To je lahek in močan les, a le če je bil na suhem. Zaradi prepletenosti z žilami ga ni bilo moč kalati, temveč je bil izvrsten za dolbenje. ${ }^{2}$ $\mathrm{Na}$ Vihrah so dolbli manjša, polkrožna korita za prestrezanje črev ob kolinah, ki so jih imenovanih nejcke oz. bance. ${ }^{256} \mathrm{Na}$ D. Skopicah so jagned uporabljali za izdelavo manjših sani, iz njegove skorje pa so otroci rezljali igračke (Rihter 2010, 30). Uporaben je bil tudi kot gradbeni les. $\mathrm{V}$ vasi Vihre še danes najdemo nekatere skednje, ki so obiti s krivimi jagnedovimi deskami (Rihter 20I0, 30). Na Bregah so iz jagneda izdelovali gajbice za hranjenje poljščin in za izdelavo zgornjih delov voza; konic in skončnikov ${ }^{257}$, predvsem pa so tod izdelovali predmete, ki so služili delu z žitom in moko. Takšna sta npr. vijavnica in skledasto polkrožno korito za mesenje kruha - banca. Prav takšne, odslužene bance, so otroci tod uporabljali za spuščanje po snegu. ${ }^{258}$ To je omogočala njihova nič manj skrbno kot notranjost, lepo zaobljena zunanjost (nehorizontalno

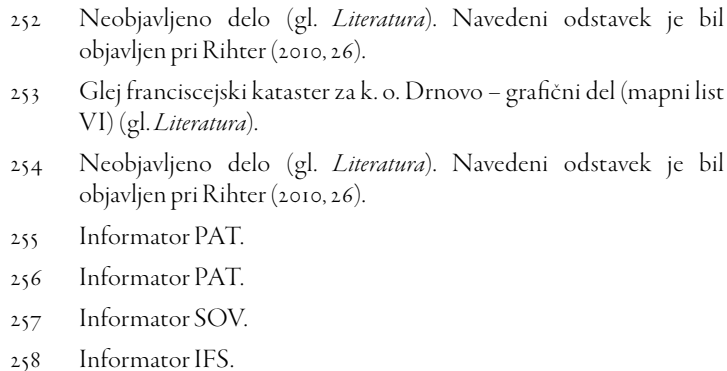


dno). V času po 2. svetovni so v vihransko Vrbino prihajali potujoči rezbarji iz Slavonije (ali Srbije in Madžarske), ${ }^{259}$ ki so od domačinov kupili jagnedova drevesa, jih posekali in na mestu samem mesec in več dolgo izdelovali različne okrasne motive (npr. živalski motivi), ${ }^{260}$ ter druge izdelke, npr. korita in bance. ${ }^{261}$

$\mathrm{V}$ luči današnje podobe nekdanje poplavne ravnice dodajamo, da so bila najjugozahodneje $\mathrm{v}$ poplavni ravnici dokumentirana tri jagnedova drevesa na holocenskih terasah pri vasi Brege, na meji ledin Traminčki in Flančišče (SL. 2). Ta so imela po izročilu veliko prostorsko in simbolno vlogo, saj naj bi bila simbolično potaknjena na mejo med pašnikom in vaško zemljo (Rihter 2015, 239, Op. 343). Izročilo pravi, da je praded Jurečič iz Breg pri določanju meje med pašniki in njivami šel k takratnemu jagnedovem drevoredu ob cesti, nalomil veje, jih prinesel $\mathrm{k}$ meji in jo označil tako, da je vejice potaknil v linijo. Tri zaporedne vejice naj bi vzklile in zrasle v velika drevesa, ki so jih ohranili kot mejnike. Izročilo še pravi, da so to pomembno dejanje razmejitve polja od pašnikov, ob veliki udeležbi vpletenih, obilno »zalili $\ll \mathrm{z}$ vinom. ${ }^{262} \mathrm{Ob}$ komasaciji zemljišč je prišlo leta 2013 do menjave lastništva in posledičnem nepričakovanem poseku le-teh, nakar se je prebudil tudi ljudski spomin o njihovi nekdanji vlogi, ki smo ga zapisali zgoraj. Danes sta za Bregami na območjo Barnopak in nekdanje Gmajne še dva manjša jagneda, nekaj več pa jih je bilo še na skopiškem v smeri vihranske ledine Prudi. ${ }^{263}$

Današnje stanje. Osrednji del obravnavanega področja je med leti 2009 - 2014 zajela komasacija, ki je povsem spremenila kulturno pokrajino spodnjega polja. Zabrisana je parcelacija in ustroj poti, ki je izviral še iz fevdalne dobe. $\mathrm{Na}$ območju spodnjega polja med Vihrami in Brega-

Informatorji niso bili enotni v navajanju narodnosti. Nekateri omenjajo potujoče Rome. Vilko Novak je v etnografski študiji na območju Prekmurja ugotovil, da so korita in posode iz jagnedovine tam dolbli Romi (Novak 1947, I20).

260 Informator IFS

26I Informatorja CAR in PAT.

262 Informator RVF.

263 Informator PAT. mi v obsegu komasacije so (ne)posredno izginile številne mejnice na vihranskem (ob poti na relaciji Brodišče-Zgorelo), na brižanskem (Hančave lastine, Stara gmajna, Zavrbenice, Naša vrbina) ter večina starih markantnih osamelcev, npr: edini hrast na ledini Pod vrbe, edini hrast na ledini Naša vrbina, osamelci različnih vrst vzdolž Velikega savišča, že omenjeni trije mejni jagnedi na meji ledini Traminčki/Flančišče (gl. Jagned) (Rihter 2015, II-I4), tod najstarejši osameli glogovi drevesi (!) nad Podmališčem. idr. Omenjenemu neprimerljivo in večje uničenje naravne in kulturne pokrajine pa je pomenila izgradnja akumulacijskega bazena za HE Brežice, ki - po savski regulaciji - pomeni doslej najradikalnejši poseg v dosedanji obrečni prostor (prim. Hudoklin I993; 2008, i-iii; Brečko 2008).

\section{Hrast}

Pričevanja o gospodarski izrabi vrbinskih hrastov so redka. Vemo, da jih vrbinski pastirji niso marali za kritje $\mathrm{v}$ slabem vremenu, zaradi strel. ${ }^{264}$ Razpolagamo pa s podatki o svinjski paši pod hrastovimi drevesi in uporabi za zdravljenje (gl. Zdravilne ...). Zanimivo je pričevanje o hrastu, kot pomembnem mejniku na spodnjem polju brižanske vrbine, nekje na območje ledine Borovnice in Stare vačke, kjer je potekala vzhodna poljska meja med vasjo Brege in Mrtvice.

Brižani smo pasli do Struge, ${ }^{265}$ kjer je v stru-
gi tekel majhen potoček, nekje ob meji z
mrtviškim. Tem potočku smo rekli Struga.
Tam, na meji je rasel osamelec, edini hrast
od Zavrbenic naprej, za katerega nihče ni
vedel koliko sto let star je bil. Zraven hrasta
je bila struga, ki je danes ni več in do tam
smo smeli pasti. Stal je na meji med našim in
mrtviškim. Tako je pripovedovala stara ma-
ma, ${ }^{266}$ ki me je enkrat peljala do tega drevesa
in mi je pokazala mejo. ${ }^{267}$
Informator FSI.
Natančneje nelociran toponim. Zelo verjetno gre za
mikrotoponim znotraj ledin Malo in Veliko savišce ali v njuni
neposrednibližini.
Informator EKC. Stara mamaje umrla leta i94ov starosti 83 let.
Informator EKC.

267

\section{4}


Stari Mrtvičani so namreč kričali, če je živina ušla preko meje. ${ }^{268}$ Ta potoček, bržkone zarisuje že t. i. avstrijska vojaška specialka iz leta 1882 in v nadaljnih letih vse do leta $1943 .{ }^{269}$ Po tej karti je gotovo, da je izviral in tekel po strugi na ledini Veliko savišče, ki jo predstavlja star meanderski lok oklepajoč ledini Borovnice, Stare vačke in druge. Verjetno je šlo za podobne okoliščine, kot pri potočku, ki je izviral na ledini Studenec na gorenjeskopiškem (gl. Ribolov).

Jelsa

Uršula Vodopivec je zapisala:

\section{Jaged je v Vrbini najpogostejše drevo, bolj na mokrem svetu pa jelše (Alnus sp., op. J. R. ). $\mathrm{V}$ prejšnjem stoletju je raslo še veliko število vrb. Sedaj so se posušile. (Vodopivec 2008, p. $\left.69-70^{270}\right)$}

Kot že omenjeno, so jelše obraščale remensko strugo na brižanskem spodnjem polju, na predelu Delečki. ${ }^{271} \mathrm{Na}$ G. Skopicah so jelšev les uporabljali za tla v živinskem hlevu, ki so ga cenili zaradi trajnosti v mokrem okolju (Vodopivec 2008, p. $\left.7 \mathrm{I}-72^{272}\right)$. Na Bregah je hlev Vinka Škofljanca, zgrajen leta I900, ki ima še vedno deloma originalen jelšev tlak iz $20 \mathrm{~cm}$ dolgih in v premeru I2 $\mathrm{cm}$ širokih prečnih rezin jelševih debel. Stari rejci naj bi izdelovali izključno tovrstne pode, saj so na podlagi izkušenj menili, da takšna tla živini in konjem zagotavljajo varno vstajanje, predvsem pa z svojimi robovi in medprostori onemogočajo drsenje nog. Podoben učinek razgibanosti in opore $\mathrm{v}$ tlaku hlevskih tal so dosegali s tlakovanjem z velikimi prodniki in lomljenci. Ostanke takšnih izvedb tal smo pred leti še lahko videli na nekaterih domačijah, npr. pri stari p. d. Rahličevi domačiji na Bregah (gl. Prodniki).

$\mathrm{Na}$ skopiškem so $\mathrm{v}$ poletnih mesecih kurili jelšev les, ker ta ni imel posebne kalorič-

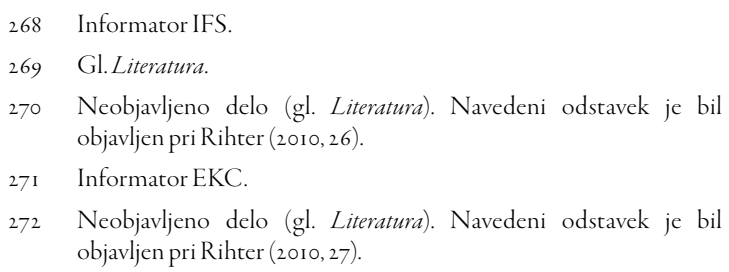

ne vrednosti (Vodopivec 2008, p. 7I-72). Jelševina za poletno kurjavo je znana tudi iz drugih poplavnih ravnic (prim. Novak 1947, I17). Na brižanskem se je jelševina $\mathrm{z}$ Velikih vod prodajala mizarjem, ki so jo cenili npr. za izdelavo obročkov za karnise. Na Bregah je izpričana njena uporaba tudi za platišča vozov. ${ }^{273}$

\section{Jesen}

Jesenov (Fraxinus sp. ) les so na Vihrah cenili za izdelavo delov vozov, na Skopicah so ga uporabljali za izdelavo smuči s postopkom kuhanja in uvijanja (Rihter 2010, 30), podobno na Bregah in Vihrah. ${ }^{274} \mathrm{Na}$ splošno pa je bil tod priljubljen za izdelavo raznih ročajev. ${ }^{275} \mathrm{Na}$ Bregah so jesenovino sekali v Zlatičju, jo skobli in s pomočjo toplote in šablon ukrivljali za smuči. Sicer pa je bila tod jesenovina nepogrešljiva za špice voza in za kosišča. ${ }^{276}$

\section{Vrbe}

Med drevesnimi vrstami po omembah izstopa obilje različnih vrst vrb (Salix sp. ), ki je postalo ob savski regulaciji še izdatnejše. Osnovni naravni gradniki za utrjevanje savskih brežin so bile namreč vrbe oz. t. i. vrbove fašine. ${ }^{277}$ Vrbe so na savskih obrežjih sicer rasle samoniklo, na reguliranem kanalu pa sprva kot posledica utrjevalnih del, gojene pa naj bi bile bile tudi $\mathrm{v}$ nasadih (D. Skopice) (Rihter 2007, 35; 2010, 30, 35-36; op. 23 in 43; 2015, 69). Nasade in porasle brežine so »savski mirkači < kakor so na Bregah pravili čuvajem savskih obrežij, čuvali pred nenadzorovanim sekanjem. To bi namreč ogrožalo trdnost brežin. $\mathrm{Na}$ ta način so varovali tudi naravne zaloge za izdelavo novih fašin za utrjevanje spodžrtih brežin. ${ }^{278}$ Neupravičeno rezanje vrbovih šib v Vrbinah pod Zotterjevo pristavo (severno od Žadovinka), navaja Majda Smole po graščinskih

273 Informator IFS

274 Informator IFS, RVL, PAT.

275 Informator CAR.

276 Informator RVF, IFS.

277 SSKJ: fašina -e ž (i) grad. butara protja za dreniranje ali utrjevanje rečnih bregov.

278 Informator IFS 
arhivih Šrajbarskega turna (Smole i980, 9I). Šlo je za organizirano službo varovanja in popravljanja spodžrtih brežin, za katere nosilca se je v ljudskim spominu ohranilo poimenovanje savski inženir ali inšpektor. Na Bregah se v tej vlogi v 19. stoletju omenja Škofljanec. Kot izvajalec del oziroma savski delavec pa Završnik. ${ }^{279} \mathrm{~V}$ Dolenjih Skopicah je o tej dejavnosti ohranjen spomin, da so ljudje iz vasi hodili na delo v brežiški grad, kjer so pletlifašine ${ }^{280}$ za utrjevanje brežin. Na območju Čateža pa naj bi delavci vodne skupnosti tovrstne fašine izdelovali še v 1960-tih in 1970tih, ${ }^{281}$ kjer je od leta 1938 dalje kot rečni načelnik deloval Franc Avšič (Teppey 1977, 29). Ugotavljamo, da bi bilo pred desetletji možno v tu obravnavanih vaseh še pridobiti prvoosebna pričevanja o načinu in poteku tovrstnih del predvsem na skopiškem območju, kot jih omenja Uršula Vodopivec (2008).

Ljudem so tako negovani, mladi obrežni nasadi vrb izjemno ugajali za pletarstvo v okviru domačih potreb. Zaradi periodičnih človekovih utrjevalnih posegov ob reki, so se stari nasadi pomlajevali, hkrati pa nastajali novi. Tako je bilo primernega materiala - maldic - vedno dovolj. Tudi v času pred rečno regulacijo, si lahko verjetno predstavljamo podobno izobilje samoniklega vrbja, ki je ob spremembah rečnih strug, kot pionirsko, poraščalo vedno nova prodišča in brežine. Že pred 2. svet. vojno so na Skopiškem vrbove šibike nabirali za prodajo, kupci pa so bili razni korbarji, ki so pletli korbe za blagoslov velikonočnih jedi; manjše korbe $\mathrm{z}$ locnjem, cekarje za raznovrstno rabo in tudi stole (Vodopivec 2008, p. 69-70 $0^{282}$ ). K tej omembi pritegnimo še poročilo iz tedanjega Brežiškega okraja, objavljeno v Slovenskem gospodarju, ki pravi, da so leta I90 I zaradi velikega zaledja $\gg$ vrbin $\ll$ z vrbami, $\mathrm{ki}$ jih je bilo v nekaterih občinah od 40-60 oralov

\footnotetext{
279 Informator VER, EFF, STM.

280 Informator TXJ.

28I Informator TXJ.

282 Neobjavljeno delo (gl. Literatura). Navedeni odstavek je bil objavljen pri Rihter (2010, 26).
}

in so jih do tlej kupovali italijanski kupci, celo razmišljali o ustanoviti pletarske šole. ${ }^{283}$

Še zlasti je bila tod priljubljena vrsta im. zlatikona ali zlatika (Salix sp.). Njene enoletnice so cenili za izdelavo špal in za pletenje košar. Rasla je na savskih obrežjih, največ pa so je nabirali na ledini Zlatičje, ki naj bi po ljudskoetimološki razlagi dobila ime prav po zlatiki oz. zlatikoni. Zlatikono Brižani opisujejo kot vrsto vrbe, ki je pod lubjem rumene barve in so jo cenili za izdelavo špal in za pletenje.

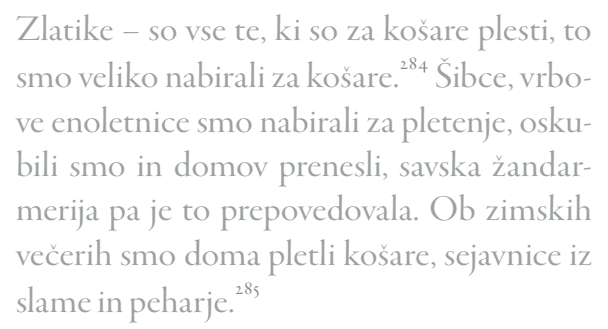

Sicer pa je bila izdelava špal pogosto delo pastirjev na paši, ki so s žepnimi nožiči klali vrbove veje, ${ }^{286}$ izdelovali pa so jih tudi iz maklena.

Tudi pletar Bogolin z Mrtvic - ki ga na Krškem polju kot prodajalca košar, košev in jerbasov pomnijo na drnovskih in drugih sejmih, ${ }^{287}$ je svoje surovine pridobival $\mathrm{v}$ poplavni ravnici. Imel je namreč svoj vrbov nasad v stari strugi pod vasjo. ${ }^{288}$ Njegov repertoar izdelkov je natančneje opisala Ljudmila Bras. Izdeloval je koše in košare iz surove, nebeljene vrbe, pisane locnjevke, bele jerbase toplarje z dvojno kito, košare za perilo, zibke in koše za mošt (Bras 1970, II).

Od brižanske vrbine in Zlatičja gorvodno, v smeri Krškega, kjer so bili osušeni savski tokovi že dokaj oddaljeni od regulirane struge, so v I930-tih določene predele že prodajali za posek zlatike $\mathrm{z}$ namenom oskrbe s kurjavo. Iz vzhodnega dela tega območja je znana tudi lomenjena edina Zlatičje, ki naj bi po ljudskoetimološki razlagi dobila ime prav po zlatikoni. S takimi po-

\footnotetext{
283 Slovenskigospodar, 28. I I. I90 I.

284 Informator VKC.

285 Informator EKC.

286 Informator EKC.

287 Informator TTR.

288 Informator IFS
} 
seki so dopolnjevali oskrbo z drvami, še posebej tisti, ki niso imeli lastnih gozdov v krakovskih gozdovih. $^{289}$

Vrba, beka (Salix viminalis) in še neka druga vrsta vrbe $\mathrm{z}$ od beke boljšimi lastnostmi za vezavo, je bila tedaj še povsod osnovna surovina za vezavo v vinogradništvu. Na Drnovem so jo poleg tega, uporabljali tudi za žlimaje/žlemaje svinjskih črev. ${ }^{290}$ Brižanski pastirji so izdelovali veliko izdelkov iz mladega vrbovega lubja, pezde$c e$, piščalke in rogove. ${ }^{291} \mathrm{Na} \mathrm{D}$. Skopicah so tako izdelan rog imenovali horn ${ }^{292}$ (Rihter 20I0, 30), prav tako na Drnovem. ${ }^{293}$ Uršula Vodopivec piše, da so jim med vojno, ko so bili izgnani v delovna taborišča v Nemčijo, Kočevarji posekali vse domače beke na dvorišču in po vrnitvi iz internacije niso imeli s čim vezati. Zopet so se zatekli v Vrbino, a tam, niso več dobili dovolj kvalitetnega šibovja za vezavo (p. 69-7094). To pomanjkanje bi bilo možno razložiti s tem, da med okupacijo na določenih odsekih ni prihajalo do rednega pomlajevanja nasadov $\mathrm{z}$ utrjevanjem brežin, zaradi česar tudi ni bilo ustreznih mladic za pletenje ali vezavo.

\section{Leska}

V brižanski vrbini ob poti čez ledino Remen, na razdalji med Delečki in Zaromani so bili pred izgradnjo letališča Remen (tj. pred letom 1937 , prim. Ravbar 2008), na obeh straneh poti, z grmovjem poraščeni jarki z nasipi. Ti so varovali pred ubegom živine na travnike. V tej mejnici je bila najbolj zastopana vrba, črni trn, glog in leska (Corylus avellana). Tu so spomladi nabirali leskove šibe $\mathrm{v}$ mezgu za pletenje košar $\mathrm{z}$ locnjem in jerbasov za velikonočni žegenj in jerbasov za prenašanje dojenčkov. Pravočasno olupljene leskove šibe so bile bele barve, kar je dajalo izdelkom posebno vrednost. Belina jih je izvzemala iz vsakodnevne rabe; takšni izdel-

$\begin{array}{ll}289 & \text { Informator IKC, VER. } \\ 290 & \text { Informator MIM, SJR. } \\ 291 & \text { Informator EKC. } \\ 292 & \text { Horn ali rog je bilo glasbilo (trobilo). } \\ 293 & \text { Informator SJR. } \\ 294 & \begin{array}{l}\text { Neobjavljeno delo (gl. Literatura). Navedeni odstavek je bil } \\ \text { objavljen pri Rihter (2010, 26). }\end{array}\end{array}$

ki so bili ponekod v uporabi le ob praznikih. ${ }^{295}$ Uporabljali so jo tudi za izdelavo špal za špiljenje klobas ${ }^{296}$ in nosilnih kolov za dimljenje mesa. ${ }^{297}$ Nekateri Brižani so za nosilne kole pri dimljenju uporabljali tudi drenov les (Rihter 20I0, 30), ki naj bi ga po nekaterih podatkih sekali nekje na Gmajni in pri nekaterih hišah uporabljali tudi za špale, ${ }^{298}$ enako kakor maklenov les (Rihter 20ı, 30). Iz leske so izdelovali locnje za ribolov z mrežo na križ. Izbrane kole premera do $4 \mathrm{~cm}$ so ukrivili tako, da so jih z obema koncema potaknili v zemljo in pustili nekaj dni (gl. Ribolov), da so se ukrivili. Pastirske palice so bile iz leske in praviloma okrašene z vzorci napravljenimi z izmeničnim izrezovanjem lubja. ${ }^{299}$ Leska je bila po vseh vaseh nepogrešljiva za koljenje visokih sort fižola, v otroški igri pa za izdelavo lokov. ${ }^{300} \mathrm{O}$ široki uporabi leske govori naslednji odstavek:
Stric je prepletene biče delal - lesen del je iz leskove palice, zgornji del je grel in klal. Izde- loval je še vitre. En del leskove palice je od- luščil in ga obdeloval nato pa v snegu puščal, da se ni posušilo. To so vitre. Izdeloval pa jih je iz par metrov dolgih kolov, ki jih je dal v peč, olupil, nato pa z nožem luščil par mili- metrov na debelo, nato pa spet in spet luščil, da je dobil tanke vitre. Na usnjenem kolenč- niku jih je z nožem fino obdelal. Nato pa jih je dal v sneg, da se niso izsušile. Ostanki leske so bili za locen. Košare je delal nato iz viter. Tako narejene košare so bile za na njivo in za vse iz njive domov prinesti. Koši so imeli šir- še vitre. Za sejanje so bile košare iz slame, im. sjavence. Pozimi je pripravil še brezov les za popravila na plugu. Grablje so prav tako na- redili iz leske, vse iz Vrbine. ${ }^{301}$

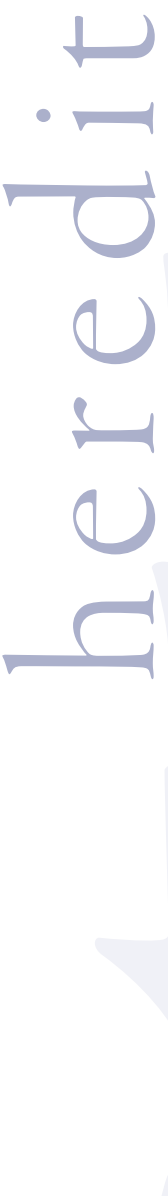

295 Informator VER

296 Informator VER

297 Informator IFS.

298 Informator IFS

299 Informator EKC.

300 Informator SJR.

301 Informator EKC. 
Na Drnovem so iz leske izdelovali mreže za sušenje lanu in konoplje kot delov zidanih sušilnic. ${ }^{302}$ Gradili pa so na Drnovem tudi iz protja pletene in z ilovico ometane peči za sušenje lanu. ${ }^{303}$

\section{Stelja}

Grabljenje stelje na skopiškem v tridesetih letih preteklega stoletja omenja Uršula Vodopivec:

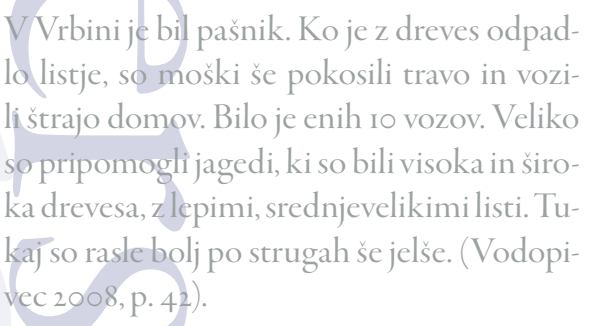

Na brižanskem pašniku Gmajna, kjer so izvajali skupno pašo navpreko, čeravno na razparceliranih delcih, so vsako jesen vse kmetije opravile še čistilno košnjo za steljo, a sedaj le v okviru svojih parcel. S tem so pašnik pripravili na počitek še pred zimo. Šlo je za nekoliko obraslo travo v šopih, ki se je obrasla od poletja le okrog gladeža in drugih bodečih ali živini neokusnih rastlin. Takšna stelja ni bila cenjena, saj pogosto poročajo o poškodbah rok z rastlinskimi bodicami.

\section{Polajc in gladiž rasteta na Gmajnah, tega je bilo veliko in kačji stric. Za steljo je bil vmes, vendar gaživina ne mara. ${ }^{304}$}

Vrbinske stelje tisti z gozdovi v Krakovskem gozdu niso potrebovali, saj so obilnejšo strajo dobili kar tam. Zato so jesensko/predzimsko košnjo na Gmajnah odstopali tistim, ki niso imeli drugih možnosti za pridobivanja stelje. Ta košnja je bila sicer nujna predpriprava pašnika za drugo leto in je zato vselej moral dočakati zimo očiščen. ${ }^{305}$

\footnotetext{
302 Informator STA

303 Informator ALS.

304 Informator VKC.

305 Informator VER in IFS.
}

\section{Gradbeni materiali}

\section{Ilovica}

$\mathrm{Na}$ Bregah so koristili ležišča ilovice za domače potrebe na ledini Globajnk, na Vihrah na ledini Pod belim bregom in na ledini Prudi. Nobeno ležišče danes ni več vidno oz. odprto. Znano je, da je šlo za manjše kope na mestih, ki so jih naznanjala močvirna območja. Koriščenje ilovic je jenjalo s pričetkom 2. svetovne vojne oz. s povojnimi spremembami v načinu gradnje. Zato tu danes ni nobenega ohranjenega kopa več. Zanimala pa nas je primernost ilovic za opisane in druge potrebe. Odgovore so ponudila opažanja v neposredni bližini znanega starega kopa v Globajnku, in sicer na sosednji ledini Podmališče, ki ju povezuje ista struga. Nedavno je tamkajšnji izkop za vodovod na liniji Brege-NE Krško, pokazal, da se pod I,5 $\mathrm{m}$ pretežno poplavnih muljastih peščenih naplavin pričenja naplavina mazave sive ilovice $\mathrm{z}$ vključki rjavo obarvanih peg. ${ }^{306}$ Enaka ilovica je prisotna tudi na Drnovem pod vasjo, na prvi terasi im. Zevniki, kjer se na okoli $2 \mathrm{~m}$ globine, pod čistimi ponekod pa pod muljastimi peščenimi naplavinami, pojavi do I $\mathrm{m}$ debela naplavina ilovice, ki se useda neposredno na peščenoprodnati zasip. Prehod med njima pa je obarvan rjavordeče v debelini okoli Io $\mathrm{cm} .{ }^{307}$ Poizkusi so pokazali, da je to ilovico možno oblikovati in tudi žgati. Sklepamo, da je na Bregah in na Vihrah šlo za izkoriščanje opisanim podobnih naplavin ilovice.
Na brižanskem v Globanjku je bila rjava gli- na. Naša stara mama so jo hodili iskat za bru- ne fugirat v skednju. Notri so dali ovsene ple- ve in to z nogami zmesili do gostote testa za kruh. S to zmesjo so spomladi, ko se je oto- plilo, zafugirali vse reže v tleh in stenah ske- dnja. Mi smo doma vršili žito v skednju s kra- vami ali konji in smo potrebovali zatesnjena
Vidno dne, 27. 12. $2013 \mathrm{v}$ več izpraznjenih jamah, ki so bile izkopane ob naknadnem odkopu spojk že položenih vodovodnih cevi na celotni trasi sicer ravnokar položenega vododvodnega voda na območju struge Podmališče, do poti Žadovinek-Velike vode (avtor prispevka).
307 Takšno situacija je bila dokumentirana dne 13. 5. 2009, na liniji izkopa za kanalizacijo preko njiv ledine Zevniki (avtor prispevka). 
bruna, da žito ni uhajalo. To je imela pri nas stara mama čez. Tam v Globajnku, kjer so kopali glino je v jami ostajala voda - tam smo verjeli, da prebiva povodni mož. Tudi lesene hiše iz brun so zamazali s to glino, le da so jih pobarvali še z modro in belimi pikicami. $^{308}$ Kadar pa je na svinjakih odpadel omet sva s staro mamo, s prav tako zmesjo ilovice in plev ter s pomočjo kalanih leskovih palic kot armature, popravile poškodbe. ${ }^{309}$

V Globajnku so Brižani jemali ilovico tudi za zdravljenje rdečike pri prašičih. Umešali so jo z vinskim kisom in mazali po koži. ${ }^{3 \mathrm{IO}}$ Kaleš, raztopino kravjega blata in ilovice, ki so ga na Bregah uporabljali za presajanje krmne pese na strnišče (gl. Flančǐ̌če), ${ }^{311}$ so prav tako pripravljali iz ilovice iz Globajnka. ${ }^{312}$

$\mathrm{Na}$ Vihrah so v Margečevi strugi Pod Belim bregom Vihrani dobili »sivo blato «, ki so ga uporabljali za zamazovanje tal $\mathrm{v}$ hišah (za praznike so tla poflikal ${ }^{13}$ ) in za tesnenje prostora, kjer so mlatili žito in so ga na Vihrah imenovali uguna (gumno). ${ }^{314}$ Kot še pravijo na Vihrah, so »posebno zemljo《 ali »rjavo glino za izdelavo tal v zgradbah nekdaj kopali tudi na ledini Prud. Njena ležišča so naznanjali predeli na katerih je zastajala voda, kopali pa so do I m globoko. ${ }^{315}$

O še nekem mestu, kjer so prvotno najverjetneje kopali ilovico, kasneje pa (izpričano) predvsem pesek in prod, morda priča ledinsko ime Brnokop na Skopiškem in temu zvočno podobno ime Brnopake ali Barnopake na brižanskem. Besedo brnokop razlaga L. Pintar, kot kraj kjer se koplje prst ali ilovica za tlakovanje (Pintar i895, 4). V narečni slovenski besedi brn pa je ohranjen pomen $\gg$ rečno blato, mulj $\ll$, brna $\gg$ ilovica, zemlja, humus« (Snoj 2009, 82-83). V Pleteršnikovem slovarju najdemo brnje, kot die Dammerde

\footnotetext{
308 Informator VER, ELK.

309 Informator ELK.

3 Io Informator VER.

3I I Informator IFS.

312 Informator IFS.

313 Informator CAR.

314 Informator CAR.

315 Informator RMI
}

v nemščini ${ }^{316}$, kar Ivan Zelko pri obravnavi Prekmurskih ledinskih imen prevaja kot »črna prst« (Zelko 1985, 460). Kopanje rodovitne zemlje za rož $e^{317}$ ter peska in proda je izpričano na Bregah, ob robovih ledine Barnopake, ki je toponim za staro strugo. V njej je ob zahodni brežini, pod teraso Vrti, potekal pas srenjskega zemljišča, ${ }^{318}$ kjer so imeli vaščani po izročilu odprte manjše skupne kope proda. Med njimi so bili nekateri opuščeni že pred 2. svetovno vojno, saj so vanje že takrat odvažali hišne odpadke. ${ }^{319} \mathrm{Na}$ ledini Barnopake so v grmovju kopali humozno zemljo za rože in druge domače posevke še $\mathrm{v}$ 90-ih letih 20. stol. ${ }^{320}$ Vzdolž nasprotne, zahodne brežine Barnopak, so imeli pred 2. svetovno vojno pas majhnih gojitvenih vrtov-flančišč, ${ }^{321}$ ki naznanjajo prehod Barnopak $\mathrm{v}$ obširno ledino Flančišče proti zahodu (Gl. Flančišče).

Kopanje na ledini Brnokop na skopiškem dodatno osmišlja ljudski spomin na že pred letom 194I odprte kope; omenjata se dve jami, ${ }^{3}$ kasneje pa je to področje prečkala avtocesta in danes niso več vidni. Zaenkrat žal ni natančneje znano, kaj so v omenjenih jamah kopali.

V Gorenjih Skopicah so (v času velike noči) glino za lesene hiše fugirat ${ }^{323}$ kopali za vasjo na Stazah. Šlo je za sivo glino, ki so jo mešali z pšeničnimi plevami. O primernem ležišču ilovice za izdelavo opek priča tudi v izročilu ohranjen podatek o obstoju opekarne na vzhodnem robu Dolenjih Skopic, ${ }^{324}$ kjer so v letih 1900 in 1901 izdelali vso potrebno strešno in zidno opeko za izgradnjo nove cerkve sv. Marka v Cerkljah ob Krki, kakor poročajo domačini ${ }^{325}$ in župnijska kronika (objavljena pri: Smuković 20I4, 243).

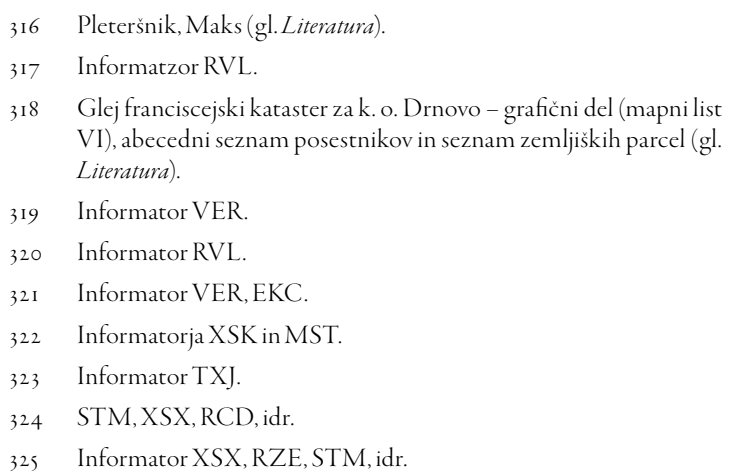


Lokacija opekarne sovpada z arheološkim najdiščem Dolenje Skopice - Arheološko najdišče Ravne, kjer naj bili nekateri ostanki kamenja, opeke in lončenine, prepoznani kot rimskodobni. ${ }^{326} \mathrm{Na}$ tem mestu, ki so ga značilno imenovali Ciglana, so domačini dobili

\section{ilovko za mazat po hišah. ${ }^{327}$ Ciglarna je bla tu, rekli so Pod črešje. Bil je ohranjen še kos zida. Se je vidlo od deleč. ${ }^{32}$}

Ta podatek se nanaša na čas 1930-1940. Opekarna pa naj bi po mnenju nekaterih prenehala $z$ delovanjem že pred I. svetovno vojno. ${ }^{329}$ Krajevni leksikikon dravske banovine $(1937,258)$ omenja opekarno tudi v Gorenjih Skopicah.

\section{Sviž in prod}

$\mathrm{V}$ vseh obarvnavanih vaseh se je pred drugo svetovno vojno droben pesek, ki ga tod imenujejo sviž, črpal izključno na spodnjem polju (holocenske terase). Prod pa se je v tistem času kopal ob glavnih cestah predvsem za njihovo oskrbo in to skoraj izključno na pleistocenski terasi. Pogosto so se kopi nadaljevali kar na robovih starejših kopov, v katerih so sicer že uspevali travniki in njive. Med njimi so namreč v okolici Drnovega nekateri zelo verjetno še rimskodobne starosti (Rihter 2015, 209-216).

Za ceste so skrbeli domači zogarji, ${ }^{330}$ ki so - kot že rečeno - prod črpali v nekaterih starih kopih, hkrati pa so deloma že odpirali tudi kope na svojih zemljiščih v bližini cest (npr. Brege). Nove kope so odpirali v času okupacije tudi Nemci predvsem na območjih, kjer so gradili t. i. avionske ceste, $s$ katerimi so povezali glavno letališče v Cerkljah ob Krki, z zakloni za letala na poraščenih obrobjih polja bližje reki Savi. Večji kop proda je v tem času (med okupacijo) na novo nastal južno od c. sv. Urha na ledini Pri križi ${ }^{33}$, ki je trenutno $v$ fazi zasipavanja. $V$ času okupa-

Dolenje Skopice - Arheološko najdišče Ravne (EŠD I0779)): Dostop: http://giskd6s. situla. org/giskd/ (17.08. 2019).

327 Informator RCD

328 Informator STM

329 Informator TXJ

$330 \mathrm{~V}$ pomenu cestni delavec.

33 Informator FSI, VER, EXC, LPT, XSX cije so zaradi umeščanja avionske ceste pri ledini Mrtvišce, znatno povečali tudi kop proda pri Bregah na mestu, kjer je kasneje domovala »gramoznica in cementnine Brege « kasneje del IGM Sava Krško. ${ }^{332}$ Do takšnih posegov v brežino in prod, je med 2. svetovno vojno prišlo tudi na Vihrah na ledini Drašca. ${ }^{333}$

Ko je po drugi svetovni vojni prod postal prevladujoč gradbeni material za zidavo, so se nekdanji obcestni kopi zaradi ugodne prometne lege nesluteno razširili daleč onkraj nekdanjih meja. Za nazornejšo ilustracijo - na drnovskem zahodnem robu se je stari kop proda, ki je še leta 1824 meril 7 arov, do danes povečal za 1600-krat (Rihter 2015, 174), na Bregah je južno od vasi takšen kop uničil več kot 42 ha dotedanjih njiv. Med Drnovim in Gorenjo vasjo pa skoraj 6oha. Samo na razdalji $\mathrm{I}, 5 \mathrm{~km}$ med Bregami in Drnovim, je bilo od 1970-tih let in do danes trajno uničenih več kot Iooha nekdanjih njiv. Na neodgovorno in kratkovidno gospodarjenje Krške občine $z$ umeščanji kopov proda na ekološko krhko ravnico, je že leta 1977 opozarjal Albin Stritar (Stritar 1977, 637), vendar so se od tlej nekatere gramoznice še razširile.

Posvetimo se sedaj pregledu razvoja kopov sviža na spodnjem polju, ki nas tu najbolj zanimajo. Če so se kopi proda vidneje razširili šele po sredi 20. stoletja, je za kope sviža, ki so vezani izključno na spodnje polje, značilno, da so se razmahnili že konec 19. in v začetku 20. stol. Ta trend v okviru Drnovega povezujemo z obnovami drnovskih pogorišč (prvič po lesenih gradbenih fazah), v zidani izvedbi z opeko. Drnovo je namreč med leti 1899 in 1915 , torej v samo 16-letnem obdobju gorelo kar devetkrat, do konca druge svetovne pa še najmanj $3-\mathrm{krat}$. Izmenoma so pogoreli skorajda vsi vaški predeli, nekateri tudi po večkrat in to v istem letu (Rihter 2015, I70). Povečane potrebe po svižu so ta čas zaznavne tudi v drugih tukajšnjih vaseh in so povezane $\mathrm{z}$ novim načinom gradnje $\mathrm{v}$ opeki in izdelavi značilnih glajenih fasad pogosto oker barv, $\mathrm{z}$ dekorativnimi elementi še zlasti ob odprtinah ali

332 Informator VER, IFS

333 Informator LPT 
nišah v zatrepu ali na vogalih, katerih glavna sestavina je sviž. Takšne zgradbe naj bi po izročilu v zimskem času gradili krškopoljski zidarji, ki so sicer gradili zagrebško secesijo. ${ }^{334}$ Dejavnost opekarstva na bližnjem brežiškem prostoru je raziskala Ivanka Počkar (2000, 200ıa). Manj znane pa so območju naše obravnave bližnje opekarne, nekatere med njimi sicer mlajšega nastanka, v vasi Gorica, Pristava, Velika vas in Gorenja vas (prim. Pirc 2014, 162, 165; Rihter 2014, 48; Horvat 2014,200 in 211 ).

Iz izročila vemo, da navkljub velikim potrebam po mivki, srenja Drnovega pred 2. svetovno vojno ni dopuščala nekontrolirano črpanje sviža, četudi pogorelcem iz sosednjih vasi. Vendar je bil istočasno tudi $\mathrm{v}$ drugih vaseh urejen nadzor nad skupnimi resursi na gmajnah (Rihter 20II, 4: op. 26; 2015, 173-174). O redu pri upravljanju s skupnimi viri oz. črpanju drnovskega sviža posredno priča tudi vzorna urejenost srenjskega kopa na Barovni, kot ga prikazuje fotografija Drnovega, avtorja Vekoslava Kramariča, zajeta med leti 1928-1947. ${ }^{335}$

Spodnje drnovsko polje je torej na prelomu iz I9. v 20. stoletje, s povečanimi kopi sviža na Barovni, postopoma pričelo pridobivati drugačno podobo. Več kot $2 \mathrm{~m}$ debeli nanosi kvalitetnega sviža so znani predvsem na relaciji DrašceBarovna-Flančišče. Srenjski kopi na Barovni pa so bili izkoriščani še na pragu tretjega tisočletja. Kot rečeno, imajo hiše iz preloma I9. v 20. stoletje, širom Krškega polja, že glajene notranje omete ter zunanjo fasado, za kar vse so prvič po obdobju lesenih gradenj potrebovali izdatne količine kvalitetnega sviža. Ta ni smel vsebovati organskih primesi, še zlasti ne premoga. Relativno starejše holocenske terase - kakršne tu, v bližini vasi, nedvomno so - ustrezajo temu pogoju, saj v času njihovega oblikovanja, v srednjem savskem toku še niso izpirali premoga. Povpraševanju po kvalitetnem svižu so zlasti po drugi svetovni vojni sledili posamezniki, ki so odprli kope kar na svojih njivah (Drašce, Blog, Mali blok), po razdelitvi nekaterih delov srenjskih pašnikov pa po-

334 Informator VRD.

335 Kramarič, Vekoslav (gl. Literatura). novno tudi tam - vzhodni rob Barovne na meji z ledino Flančišče in na Mali barovenci. V času izgradnje vojaških kasarn v Cerkljah ob Krki leta 1947-48 in nekaj let za tem še ob gradnji tamkajšnje nove vzletno-pristajalne steze, so se tudi na Drnovem pričeli odpirati privatni kopi sviža na dotedanjih njivah, kar je še danes vidno v obliki poglobljenih njiv predvsem na ledini Drašce, Blog in Za mlako. ${ }^{336}$ Med starejše kope sviža na drnovskem spodnjem polju lahko štejemo tiste na Barovni, zelo star kop proda in tudi sviža je bil v Gaugah na severnem obrobju drnovskega spodnjega polja, ki je izpričan že na franciscejskem katastru (Rihter 2015, 174 in 255).

$\mathrm{Na}$ brižanskem območju spodnjega polja so kopali sviž na ledini Zarbenice ali Zavrbenice. Za prod je bil na brižanskem odprt kop na meji med zgornjim in spodnjim poljem na ledini Mrtvišce. ${ }^{337}$ Sviž se je kopal tudi na ledini PlišZaroman, kajti iz tamkajšnjih predelov bližje toku Save ni bil uporaben za vsakovrstno zidavo, zaradi vsebnosti premogovih delcev. ${ }^{33^{8}} \mathrm{Na}$ Drnovem so pravili, da v nasprotnem - če se tak sviž s primesmi premoga uporablja za fine izravnave - iz sten kasneje »premog ven tolče «, torej, da na beležu pušča madeže (Rihter 2010, 29 in 2015, 172).

$\mathrm{Na}$ zgoraj omenjeni ledini Pliš-Zaroman lahko sledimo enemu največjih, še ohranjenih ročnih (!) kopov mivke na obravnavanem območju. Gre za ročni površinski kop nemških vojaških ujetnikov, ki so z nakopanim svižem in zemljo izravnavali tukajšnje rezervno travnato vojaško letališče Remen v povojnem času. ${ }^{339} \mathrm{~S}$ to informacijo dopolnjujemo leta 2012 izraženo napačno domnevo, da je tod morda šlo za strojno odstranitev, zelo velike, več kot 0,5 ha velike površine (Rihter 2016d, 249-250).

Na skopiškem so kopali sviž na ledini Malenček oz. Marlenček (Rihter 20IO, 29). Uršula Vodopivec v zvezi s kopi sviža omenja širše območje Skopiškega zaliva: »Moj oče pa, če je ra-
336 Informator JZJ.
337 Informator IFS, VER
338 Informator VER.
339 Informator FSI 
bil sviž doma, se je zapeljal na Gorenje cesarsko in tam v bližini našega tala (op. a., tj. Gorenjega cesarskega in Skopiškega zaliva) in Save, kopal jarek kot kolovozno pot proti Savi. Ko je bila leva stran že usposobljena za prevoz, se je lotil še desne strani. In tako, kos za kosom, in je bilo že izhodišče gotovo. / ... /. « (Vodopivec 2008, p. 65$\left.66^{34 \circ}\right)$. Na Skopiškem poznamo še več kopov iz povojnega obdobja, za katere še ni povsem gotovo ali njihovi pričetki segajo tudi v predvojni čas. Tod je izpričana tudi uporaba sviža v hlevu kot izravnava za jelšev tlak (gl.Jelša).

Poleg uporabe v gradbeništvu, so sviž pogosto uporabljali tudi v gospodinjstvu, npr. za zasipavanje korenja v kleteh. ${ }^{3+\mathrm{I}} \mathrm{Na}$ Bregah so železni jedilni pribor ali bištek, ki je rjal, čistili z svižem, prav tako cilindre petrolejk in litre (steklenice) ter nasplošno rjaste železne predmete. Petrolejkin cilinder se je ob svižu pral tudi s koprivami v vodi. ${ }^{342} \mathrm{Na}$ Drnovem se je sviž uporabljal kot primes pri zasipu za sajenje sadnega drevja in trt na zgornjem polju (pleistocesnka terasa).

$\mathrm{Na}$ Vihrah poznamo še lokacijo starega kopa proda, na ledini Zgorelo, ki ga je preko izročila možno posredno tudi datirati. Izročilo pravi, da naj bi tu kopali zemljino in prod med izgradnjo tamkajšnje t. i. Petrove škarpe. Material so uporabljali za izdelavo nasipa, ki so ga nato tlakovali s kamenjem $^{343}$ (Rihter 2016b, 152). Verjetno je bil kop kasneje še deloma izkoriščan, a glede na morfologijo terena (globina, oblika dna in sten) se je videlo, da vanj nikoli ni posegel strojni izkop. V času zaključne faze komasacije zemljišč, je bil ta kop pred nekaj leti zasut.

\section{Prodniki}

$\mathrm{V}$ vseh vaseh je v starejših gradnjah (kadar gre za kamnite zgradbe) zaslediti tudi večje prodnike (velikosti $30 \mathrm{~cm}$ in več) $\mathrm{v}$ temeljih, $\mathrm{v}$ manjši meri celo $\mathrm{v}$ polnilu sten zidanih zgradb. $\mathrm{Za}$ omenjene dimenzije prodnikov vemo, da jih je moč $\mathrm{v}$ večjih količinah dobiti le $\mathrm{v}$ rečnih strugah in

340 Neobjavljeno delo (gl. Literatura). Navedeni odstavek je bil objavljen pri Rihter (2010,26).

34I Informator TTR

342 Informator VER.

343 Informator CAR. še to ne na vsakem prodišču. So pa bila ta pred stoletjem vsekakor številčnejša in predvsem lažje dostopna. V starih hlevih ponekod še vidimo tlake iz velikih prodnikov (Brege) im. kugle. Tu in tam vidimo tudi manjša tlakovanja pod napušči ali pred vhodi v bivalne in gospodarske objekte ali pa nanje naletijo ob prenovah. Dotrajani stebri plotov so ponekod zagozdeni z večjimi prodniki. Ker na območju obravnavanih vasi lomljen kamen naravno ni prisoten, razen konglomerata $\left(V_{i h r e}{ }^{344}\right)$ ali pa je prisotnost kamenja povezana $\mathrm{z}$ arheološkimi najdišči v bližini, so tod za uteži pri kisanju zelja in repe uporabljali predvsem večje prodnike. Nabiranje teh v izročilu ni vezano na kope proda, saj ročni površinski kopi navadno niso dajali prodnike željene velikosti in s tem povezane teže, če že, pa so bili redki in morda tudi neprimerni. Predvsem niso smeli biti apnasti. ${ }^{345}$ Morda so prav zato poročanja o iskanju kamnov za kisanje vedno vezana na predele ob reki Savi, ${ }^{346}$ kjer je bila izbira neprimerno večja:

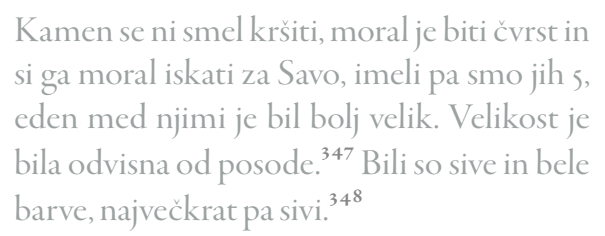

Za navajanje kokoši na stalno gnezdo so odbrali lep prodnik bele barve, ki je posnemal obliko in velikost pravega jajca. Takšen kamen so na Drnovem imenovali podlošk, v uporabi pa je lahko bil desetletja dolgo. ${ }^{349}$ Navadno je šlo že na videz za »lepše « prodnike, gladkih in skladnih površin, večinoma bele barve po obliki in velikosti podobne kurjemu jajcu. Na nekdanjih ${ }^{350}$ savskih prodiščih pa so takšni, med navidez veliko izbiro vendarle ne tako pogosti. Na starih dvoriščih in kmetijah jih je zavržene v okolici gospo-
344

345

346

347

348

349

350

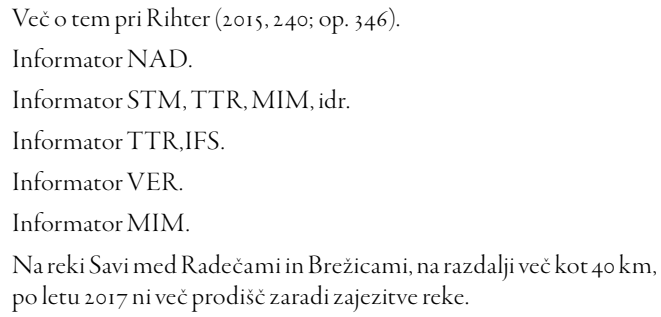


darskih poslopij (npr. pod nadstreški, kapom, ipd) možno pogojno prepoznati po zgoraj omenjeni obliki, v izjemnih primerih (v suhih kontekstih) pa tudi po še ohranjenih drobcih jajčnih lupin, ki so ostali z jajčno vsebino prilepljeni na površino kamna, kot posledice razbitja.

Vse pastirske igre, ki so vključevale tudi kamne (npr. kotlanje), so zahtevale lepo izbrane, navadno bele prodnike. ${ }^{351}$ Pastirji so s prodniki zaščitili pred živino (oz. njenim žrtjem) tudi svojo obleko na prodiščih med kopanjem v Savi. ${ }^{352}$ Odraslo divjo perjad, predvsem nekoliko večje fazanje mladiče so nekateri lovili z metanjem skrbno odbranih prodnikov velikosti okoli $5 \mathrm{~cm}$. Te so nabirali na zalogo ob priložnosti povsod, nosili pa so jih v žepu (gl. Lov). ${ }^{353} \mathrm{Na}$ ravno »lepo « oblikovani prodniki, predvsem pa kremenovi - za katere so pravili, da so za ogenj kresiti $^{354}$ - so vedno pritegnili pozornost in tako pogosto našli prostor tudi doma, čeravno zgolj v okras, kjer so se porazgubili po dvorišču. Sem sodijo tudi prodniki s predrtinami. Še zlasti oblike, ki so funkcionalno posnemale kakšna orodja, npr. brus ali sekiro tu in tam še najdemo po domovih za okras. Nekatere prodnike, ki so jih našli za Savo, so uporabljali tudi za brušenje domačega rezalnega /sekalnega orodja. ${ }^{355}$

\section{Pred zaključkom}

$\mathrm{V}$ obravnavanem obrečnem prostoru smo zabeležili tudi številne druge oblike človekove prisotnosti in njegovih dejavnosti. Ena teh je npr. prestrezanje premoga, o kateri za spodnje Posavje podrobneje beremo $\mathrm{v}$ raziskavah Ivanke Počkar (2009) in pri Živku Šebku (2010). Tu so še nabiranje naplavljenega lesa, ki pri Srednjem Marofu v Žadovinku izprčano sredi i 8. stoletja (Valenčič 1965, I87-I88) in pričevanja o kupčijah s savinjskimi flosarji in razdiranju flosov $\mathrm{v}$ brižansko-mrtviški in vihranski vrbini, ${ }^{356} \mathrm{ki}$ se

351 Informator EKC.

352 Informator EKC

353 Informator MIM.

354 Informator SJR.

355 Informator MIM, IFS.

356 Informator RMI, MRT kot trgovanje s Štajerskim lesom na Savi v Krškem, omenja že sredi i8. stoletja (Valenčič 1965, I88). Nadalje smo zabeležili spomine na poplave, brodarske in druge nesreče povezane $\mathrm{z}$ reko Savo, ${ }^{357}$ vojaške nesreče, ${ }^{358}$ poškodbe in smrti z ubojnimi sredstvi, ${ }^{359}$ pastirske igre, ${ }^{360}$ plutje po poplavljenem polju ter pričevanja o kmetijski in drugi škodi ${ }^{361}$ ipd. Tudi ti vidiki, ki jih na tem mestu podrobneje ne predstavljalamo, posredno dodatno pričajo o človekovem gibanju v tem prostoru. Tem se pridružujejo še razne vojaške dejavnosti, med njimi avstroogrsko vojaško topničarsko strelišče (Brenčič et. al. 2003, 52) in druge, kasnejše vojaške dejavnosti na relaciji Žadovinek - D. Skopice (Rihter 2016d, 247-248). Mnogo je tudi jarkov in nasipov, med katerimi so nekateri ostanki vojaških aktivnosti (Rihter 2015, 261, op. 413), drugi pa razmejitvenih del, pogosto med pašniki in njivami (Rihter 2015, 239, Op. 343, 264).

$\mathrm{Na}$ drugi strani so tu še pričakovane dejavnosti, ki pa jih zaenkrat (še) nismo odkrili v ljudskem spominu, v naravi pa jih težje prepoznavamo zaradi številnih sprememb v načinu kmetijske obdelave površin, vendar jih poznamo od drugod. Takšno je naprimer navodnjavanje travnikov, ki je izpričano v le kakšna $2 \mathrm{~km}$ oddaljeni Stari vasi onkraj Save (Ripšl 2007, I58). Ta način gospodarjenja s travniki, ki je zajemal tako namakanje kakor tudi gnojenje, je bil dobro dokumentiran npr. $v$ porečju Pšate (Radinja et al. 1976, II3). V zaledju vasi Brege ga na pašniku Gmajne in na predelu Velikega Savišča, na podlagi nekaterih topografskih znakov zaenkrat zgolj domnevamo $v$ sicer neznani preteklosti.

V vseh vaseh so izstopali posamezniki z velikim repertoarjem specifičnih znanj in potankosti povezanih s poplavno ravnico; npr. s poznavanjem nekdanjih značilnosti travnikov in pašnikov ter tamkajšnjih trav in rož na obeh

357 Informator ZHK, VER, EKC, IFS, SJR, idr.

358 Informator SJR, IKC, ZHK,idr

359 Informator VER, EKC, FSI, SJR, idr.

360 Informator VER, EKC, VVK, idr.

36I Informator DIN, DIT, STM 
bregovih reke Save, z sposobnostmi natančnega slikanja preteklih podob parcelacije, nekaterih zgodovinskih dogodkov, mest osamelih dreves in nekdanjih vodnih površin do natančnega poznavanja obsegov ledinskih imen in drugih zanimivosti. Mnogi med njimi budno opazujejo spremembe $\mathrm{v}$ poplavni ravnici že 8 desetletij in so neprecenljiv vir informacij o nekdanjem življenju tukajšnjega človeka. Tozadevno izpostavimo Elko Grilc, rojeno na Bregah, ki je bila v 1930-tih letih vrbinska pastirica, in ki še vedno spremlja pokrajino nekdanjega pašnega zaledja vasi Brege. Plod poznavanja in zanimanja za domače okolje Vrbine so tudi dokumentirani vsi večji vodostaji, ki jih na D. Skopicah že desetletja fizično beleži Jože Račečič p. d. Šavarč in so vidni v tamkajšnjem avtocestnem podvozu.

Obseg predstavljenih znanj in dejavnosti v poplavni ravnici, kaže tudi druge, neagrarne vidike človekove prisotnosti, ki jih ni moč prezreti. Takšna so naprimer pričevanja o nadnaravnem, ki jih za celovito razumevanje človekovega življenja s poplavno ravnico, ni možno obravnavti ločeno od gospodarskih dejavnosti, saj so - kot smo videli zgoraj - soočenja z nadnaravnim potekala sočasno, predvsem pa so bila del tedanje stvarnosti (gl. Mokri svet in nadnaravno). Razvidna je tudi močna simbolna vloga poplavne ravnice, ki je s svojo raznovrstnostjo naravnih in kulturnih oblik, za človeka predstavljala do neke mere neukročen svet, kar se odraža preko pričevanj o zahtevanih pastirskih veščinah in spretnostih. Zlasti na Bregah je razvidna izrazita dvodelnost paše; z nasipi in gostimi mejicami ograjen bližnji pašnik Gmajna (pri vasi) je bil v domeni otrok in star$\operatorname{cev}^{362}$ (Sl. 2). Paša izven teh okvirjev, do $2 \mathrm{~km}$ globoko v poplavni ravnici na relaciji Borovnice-Smrekce-Dolgi prudi-Sopina/Sava, pa je zahtevala starejše in izkušene pastirje in pastirice, še zlasti ob neprilikah, ki so se dogajale ob novem kanalu reke Save (neizkušenost plavalcev) in vodenju živine ob močvirni ledini Globajnk. ${ }^{363}$ Franci Škrabec z Breg zahtevnost in

362 Informator EKC, IFS, VER, SOV, idr.

363 Informator EKC, IFS, VER, SOV, DIN, RVF, idr. pomembnost paše $\mathrm{v}$ poplavni ravnici strne $\mathrm{v}$ šaljivem stavku, ki je nekdaj veljal med tukajšnjimi pastirji: »Na pule srat, v Vrbino scat, pri pastirjih pa maniro držat!«

Sledovi regulacijskih del pod vasjo Drnovo iz različnih obdobij, ki jih je opazoval in beležil že rečni načelnik Franc Avšič (Teppey 1977, 29) in tudi domnevno rimskodobnih, kot za nekatere med njimi domneva Mitja Pergar (ustna informacija), so raziskovalni izzivi, ki nas še čakajo. Obstoj rimskega mesta Neviodunum na območju današnje vasi Drnovo tik nad poplavno ravnico, nas opominja, da je potrebno rimskodobne, kakor tudi sledove drugih obdobij, pričakovati tudi v poplavni ravnici, še zlasti v zaledju Drnovega in Breg (Rutar ı899, II7-II8; Rutar in Premerstein I899, 30; Pergar in Rihter 2008, 60; Rihter 2010, 34; 2015, 69; 2016e) pa tudi Viher (Rihter 2015, 278, Op. 470). Posebno vprašanje v zvezi s tem je, v kakšnem obsegu in stanju so ti ostanki ohranjeni (Mlekuž 2009, 8-9).

\section{Zakjuček}

Raziskava zaledja kmečkih gospodarstev v poplavni ravnici reke Save na Krškem polju na območju vasi Drnovo, Brege, Mrtvice, Vihre ter Gorenjih in Dolenjih Skopic, razkriva pomen človekovega bivanja $\mathrm{v}$ neposredni bližini vodnih virov. Podaja nekatere odgovore na vprašanje, zakaj je človek naseljeval robove poplavnih ravnic in predvsem, kaj je $\mathrm{v}$ njih počel $\mathrm{v}$ prvi polovici 20. stoletja. Hkrati pa nas navaja $\mathrm{k}$ razmisleku o koristnosti teh informacij pri preučevanju preteklosti te in podobnih pokrajin $\mathrm{v}$ različnih zgodovinskih obdobjih.

Zapisali smo pričevanja tistih delov človekovih dejavnosti v konkretnem prostoru poplavne ravnice, ki pogosto ne puščajo materialnih sledi (arheologija) in niso bili pogosta tema zapisovanj (zgodovina). Se pa nanje, kot na povsem samoumnevne pogosto sklicujemo, npr. pri opisih razlogov zakaj je neka naslebina zavzela ta ali on prostor $\mathrm{v}$ nekem prostoru, npr. ob reki ali drugih vodnih površinah. 
Predstavljena pričevanja raziskovalce tega in drugih obrečnih okolj seznanjajo z možnimi in pričakovanimi nabori človekovih dejavnosti v poplavni ravnici, ki so (lahko) pustile sledove v raznovrstnih zapisih, bodisi arheoloških ali drugih, in sicer na točno določenih mestih, tako v poplavni ravnici kakor tudi v naselbinah. Nabor predstavljenih dejavnosti poraja nekatera raziskovalna vprašanja tudi za starejša obdobja v tem in drugih okoljih. Nanje bo možno odgovarjati v prihodnosti z ustrezno izbiro raziskovalnih metod $\mathrm{v}$ okviru posameznih ved. V zvezi z nabiralništvom spomnimo, da vseh dejavnosti ni možno nekritično aplicirati na starejša obdobja, na kar je opozoril že Viko Novak (1957), saj so mnoge med njimi odgovor na že spremenjene gospodraske prakse, kakršna je npr. uvedba hlevske živinoreje (Novak 1957, 20).

Pomembna ugotovitev je, da je človek v poplavni ravnici našel znaten del virov za preživljanje in da so tamkajšnje, na videz drobne individualne dejavnosti, ki so po letu 194I sicer že izgubljale pomen, dejansko predstavljale sestavni in nepogrešljiv del kmečkega življenja. Očitna količinska prevlada podatkov o koriščenju poplavne ravnice, napram količini podatkov o dejavnostih na peleistocenski terasi - ki sicer ni bila predmet pričujoče obravnave, vendar se prevlada kaže kot vzporedni/posredni rezultat te iste raziskave - kaže, da večine teh dejavnosti v suhem, zgornjem polju (pleistocenska terasa), ni bilo možno izvajati. Narava obeh polj je namreč neposredno neprimerljiva. Eden od rezultatov raziskave je torej tudi odgovor na vprašanje kaj sploh je človeku dajalo zgornje polje na pleistocenski terasi, poleg svojih, ne povsod najbolj rodovitnih njiv? Odgovor je skoraj nič iz naslova neagrarnih dejavnosti, kakršne smo spoznali v poplavni ravnici. V poljedelskem oziru je zgornje polje sicer pomenilo žitnico, vendar bi bil vtis, da je bilo zaradi tega tudi pomembnejše od spodnjega polja, napačen. Spodnje polje je namreč dajalo enako dober ali še boljši žitni pridelek ob dejstvu, da je stanovitnejše ob suši. Seveda pa je lahko bilo tudi poplavljeno, vendar praviloma ne $\mathrm{v}$ času največje suše. Gre torej za komplementaren način gospodarjenja, kjer bi bilo izključevanje pomena enega ali drugega dela polja napačno. Zato je pravilneje misliti o komplementarnem gospodarjenju v mokrem in v suhem polju, kjer pa so imele vasi z roba poplavne ravnice neprimerno boljša gospodarska izhodišča, kakor tista, ki so stala drugje. Pomembni sta bili torej obe polji, zgornje in spodnje. $\mathrm{Z}$ izbiro prostora za setev v spodnjem in/ali v zgornjem polju, je lahko človek aktivno vplival na količino pridelka v nepredvidljivih vremenskih in drugih situacijah in s tem tudi na svoj obstoj. Narava obeh polj je $\mathrm{v}$ osnovi zahtevala različna znanja in predpriprave za upravljanje, toda izplen za preživetje je bil boljši. Privlačnost takšne naselitve in takšnega načina gospodarjenja, zato ne moremo razumeti zgolj z bližino vodnih virov kot takih, npr. pitna voda, temveč v pestrosti njihovih pojavnih oblik in spremljevalnih okoliščinah, ki so jih te porajale. V občasno poplavljenih lokah in logovih je človek še pred dobrimi 70 leti tod pridobival številne surovine potrebne $\mathrm{v}$ kmečkem gospodarstvu in gospodinjstvu. Osušene in še živeče mrtvice so naseljevale živali, ki jih ob reguliranem rečnem toku ni bilo več ali pa je imel človek do njih že omejen/otežen dostop, npr. pri ribolovu in drugem koriščenju reke. Podobno velja tudi za rastline, ki so poraščale ti dve območji. Zaradi bogatstva raznovrstnega življenja, ki se ustvarja na stiku kopnega in tedaj deloma še živega in razvejanega vodnega sveta, smo tu zabeležili številna, danes že pozabljena opravila in načine ekstenzivne izrabe (Tab. I), kakršno je naprimer mokro godenje lanu v skopiških mrtvicah. Mnoge predstavljene dejavnosti prejkone, pomenijo zadnje odmeve naravnih danosti, starih navad in znanj pridobljenih s tradicijo življenja ob poplavni ravnici.

Članek posvečam pokojni Uršuli Vodopivec, rojeni Srpčič leta 1926 na Gorenjih Skopicah. 


\section{Summary}

The aim of this inquiry was to collect the last remnants of first-person accounts of farming-related activities in former wetland areas/floodplains located on the right bank of the Sava River in Krško polje (Slovenia). The process of data collection was accompanied by placing the old field's place-names onto exact points in the landscape. In the article, we presented mainly data that can be associated with a particular point in the landscape and represented by a place-name (see Fig. I and Table I). The article is focused on the floodplain area as it was in the first half of the $20^{\text {th }}$ century. During the $19^{\text {th }}$ century, river irrigation works were performed here with the aim to direct the river into a single river flow, i. e. into a channel. Because the works were slower and not as successful as planned, certain areas (including those that are part of this inquiry) in the river's hinterland continued to exist in an almost pre-regulated wetland state. It stayed like that up to the first half of the $20^{\text {th }}$ century. Likewise, some backwaters remained. This enabled the pursuance of low-intensive farming-related activities associated with this type of environment. Some of the people that practiced this kind of husbandry are still alive today and have presented us with the opportunity to get some of the last living accounts of using the damp areas as a part of domestic economy.

Following the deepening of a new river channel the water level was slowly decreasing. By the second half of the $20^{\text {th }}$ century, the area in question was no longer suitable for extensive cultivation and food gathering to a previous extent. A wide variety of activities that were taking place in the first half of the $20^{\text {th }}$ century was documented in the area of the (albeit partially dried) floodplain. They are listed in the table below (Tab. I).

The article also highlights the advantages of living in a border area between two different types of environment: The Holocene Sava terraces and the Upper Pleistocene Sava terrace. The former is characterised by being fertile and moist and the latter by being fertile yet dry. These characteristics conditioned the regional planning of crop cultivation. During drought, the fields located on the Holocene terraces were crucial. Similarly, in the case of floods the Upper Pleistocene terraces were indispensable. We identified three types of fields that are specific for the floodplain area. The first one is Flančisčce (place for breeding plants). It represents the smallest semi-cultivated area and it was usually developed in a wider pastureland area by uprooting shrubs to make place for crop cultivation. Flanišce was not permanently placed - it was in use for up to four months per year and could change location within the pastureland area. Plants (mostly cabbage and fodder beet) were transplanted from flančišce in late June. They were transplanted to the second type of field that was usually selected for this purpose after the barley harvest. These fields were located to up to a $200 \mathrm{~m}$ distance from the settlement and were typically named Drage, Drašca, Vrti and Zevniki. The third type of field forms the smallest example of micro-regional planning of crop cultivation. The best example of this field type can be seen in the Brege village (Fig. 2) with its small house gardens. The Southern part of the village is placed exclusively on the Pleistocene terrace. The Northern part's farmyards extended all the way to the first Holocene terrace below the village. The Southern part of the village had the so called »early gardens «, where the harvest of greens/ crops was earlier than anywhere else, but where the crop was destroyed in case of drought. The Northern part of the village had the so called »late gardens « on lower alluvial fields, where the harvest of greens/crops came later. This area was more resistant to drought.

To conclude: the settlements that were placed above the floodplains in this border area between two different types of environment had undeniable advantages in husbandry in comparison to villages located elsewhere. They could practice not only complementary husbandry but also plenty of other subsidiary activities involving non-agrarian exploitation of natural resources on the area of the Holocene terrace. The types of documented activities in the floodplain are listed in the table below. Every activity in the table is followed by a number for the place-name (represented on Fig. I) where this activity took place. 
Tabela ı: Povezetek glavnih človekovih dejavnosti v poplavni ravnici.

Summary of human main activities in a floodplain.

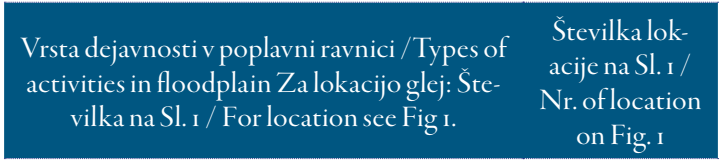

Mokro godenje lanu v mrtvici / Wet retting of flax in backwater

26

Zdravljenje s pijavkami v mrtvici; nabiranje pijavk za domačo uporabo/ Medical treatments with leeches in backwater; collecting $\quad 31,38,43$ leeches for home use

$\begin{array}{lc}\text { Ribolov v mrtvicah / Fishing in backwaters } & \begin{array}{c}26,32,33,37, \\ 39,40\end{array} \\ \begin{array}{l}\text { Ribolov v glavnem rečnem toku / Fishing in } \\ \text { the main river stream }\end{array} & 2,44,5 \mathrm{I} \\ \begin{array}{l}\text { Pranje tkanin ob glavnem rečnem toku / } \\ \text { Washing textiles in the main river stream }\end{array} & 44,50,5 \mathrm{I} \\ \begin{array}{l}\text { Pranje tkanin ob drugih vodnih virih / } \\ \text { Washing textiles in other water sources }\end{array} & 37,49 \\ \begin{array}{l}\text { Spiranje snetljivega žita / Rinsing of blast- } \\ \text { ed cereals }\end{array} & 44,47,50\end{array}$

Kopanje ilovice za domače potrebe / Quarrying clay for domestic use

$29,96,102$

Kopanje zemlje/ Quarrying soil

II, 104

Kopanje peska / Quarrying sand 9, IO, I5, 44, 6I, $73,82,83,108$, IO9, III

Kopanje proda / Quarrying gravel $9,11,39,65,69$, $72,73,104,107$, 109, 110

Nabiranje zdravilnih rastlin in zdravilnih živalskih proizvodov ter rastlinske hrane/ Collecting medicinal plants and animal products and vegetale food

$9,25,48,49,53$, $57,77,78,79$ $82,87,88,89$, $90,91,92,93$, 96, II 4

Nabiranje okrasnih in obrednih rastlin ter živali / Collecting ornamental and ceremo- $\quad 9,12,53,67,96$ nial plants and animals

Rastline za domačo izdelavo orodij in pripomočkov / Plants for home-made tools and accessories

I, 17,30, 53, 55, $56,57,97$

\section{Vrsta dejavnosti v poplavni ravnici / Types of activities in floodplain Za lokacijo glej: Šte- vilka na Sl. I / For location see Fig I.} on Fig. I

Flančišča - nestalni gojitveni vrtovi /

Flančišča - inconstant places for cultivation $\quad 7,8,9$ IO, I2 of plants

Pridobivanje lesa za gradnjo in za druge domače potrebe / Acquisition of construction wood and wood for domestic use

I, 28, 30, 53, 56, 78,79

Drevesa kot mejniki / Trees as a boundary markers or landmarks

IO, $48,95, \mathrm{IOI}$

Nabiranje plodov plodonosnega grmičevja / Gathering of fruit from fruitful shrubs

$5,33,76,77$, 78,79

Lomljenje ledu za ledenice / Acquisition of ice for icehouses

52

Izviri - potočki / Springs - brooks

$29,33,37,38,40$

$49,52,55,56$,

92,93 ,

Paša živine in konj / Pasture of cattle and $9,26,27,28,38$, $40,42,49,53$, horses

$54,56,57,78$, $79,86,96,113$

Paša gosi / Geese pasture

$21,22,52,57$ 58,61

Paša avtohtone krškopoljske pasme prašičev / Pasture of the autochthonous »Krško-polje-type $\ll$ of pigs

$9,29,57,61$

Nabiranje hrane za prašiče / Gathering of fodder for pigs

$9,17,73$

Plavanje, drsanje na ledu in druge otroške igre / Swimming, ice skating and other childhood games

$9,32,38,40,5 \mathrm{I}$, $58,95,111$

Prostori kurjenja (poletnih) kresov / Places for (midsummer) bonfires

$9,88,94,95$

Improvizirane mokre jame ob poteh za predelavo rastlinskih odpadkov v gnojila/ Improvised damp pits along the paths for pro-

II, 53 cessing of vegetal waste into manure

\section{Zahvale}

Za podatke o nekdanjem življenju s poplavno ravnico hvala vsem pripovedovalcem. Za pomoč pri opisih in iskanju rastlin v naravi ter za mož- 
nost ogleda originalnih predmetov hvala Elki Grilc, Veri Jurečič, Ivanki Kobal, Branku Srpčiču, Franciju Škrabcu in Sonji Budna. Za izdatno pomoč pri lociranju nekaterih toponimov hvala st. Francu Škofljancu, Marjanu Barbiču, Jožetu Stoparju, Vinku Škofljancu, Jožetu Račečiču - Šavarču, Janku Teršeliču, Marjanu Horženu, Anici Zahrastnik, Jožetu Gramcu, Mirku Račiču, Dušanu Lukiču, Tomažu Margetiču, Petru Račiču, Janezu in Francu Lopatiču, Slavku Žičkarju, Alojzu Golobu, Alojzu Pircu, Ani Žabkar, Ani Strle in Jožetu Urbanču. Hvala Špeli Pungaršek (Prirodoslovni muzej Slovenije, Kustodiat za botaniko) za določanje nekaterih rastlinskih vrst na podlagi ljudskih imen in opisov ter Tomiju Trilarju in Tei Knapič (Prirodoslovni muzej Slovenije, Kustodiat za nevretenčarje) za vsa dognanja v zvezi s pajkom Atypus in gosenic. Hvala Mitji Pergarju (ZVKDS, OE Ljubljana) za pogovore o poplavni ravnici in njenem izgledu v arheoloških dobah. Za kritično branje, za koristne pripombe ali za nasvete hvala Anji Mlakar, Mihi Miheliču, ZVKDS (CPA) in Timoteju Knificu (NMS). Z Inštituta za arheologijo ZRC-SAZU hvala Maji Andrič, Andreju Pleterskemu, Benjaminu Štularju, Tjaši Tolar in Borutu Toškanu.

\section{Viri in literatura}

Bavec, U. 2006. »Arheološko najdišče Gorenje Skopice - Pečina. «Varstvo spomenikov 42 (Poročila): 44-45.

Bavec, U. 2009. »Rimljani ob veliki reki poskus opisa rimske poselitve Posavja v času od I. do 4. stoletja. «V Ukročena lepotica: Sava in njene zgodbe, uredil J. Petrnel, 5I-76. Sevnica: Javni zavod za kulturo, šport, turizem in mladinske dejavnosti.

Britovšek, M. 1964. Razkroj fevdalne agrarne strukture na Kranjskem. Ljubljana: Slovenska matica.

Bras, L. 1970. Pletarstvo na Slovenskem. Vodnik po razstavi. Ljubljana: Slovenski etnografski muzej.
Brečko, B. 2008. Živi svet Vrbine. Brežice: Agencija za radioaktivne odpadke, Lokalno partnerstvo.

Brenčič, P., et al. 2003. Krško: stoletje na razglednicah. Krško: Založba Neviodunum.

Brown, A. G. 2001. Alluvial geoarchaeology: floodplain archaeology and environmental change. Cambridge manuals in archaeology. Cambridge : University press.

B. T. 2or 4. »Jubilanti. «Lovec, XCVII, September 2014: 464.

Costa, H. 1848. »Reiseerinnerungen aus Krain. Druck der Eger'schen GubernialBuchdruckerei. « Laibach I848: 103.

C. -Hoffmann, R. 1996. »Economic Development and Aquatic Ecosystems in Medieval Europe. «The American Historical Review IOI (3): 631-669.

D. Š. 1930. »Življenje in tegobe Krškega polja. «Jutro, XII (295) (2I. I2. 1930): II.

Evans, J. G. 2003. Environmental archaeology and the social order. London: Routledge.

Gugič, G. 2006. Bilten Parka prirode Lonjsko polje Vol. 8/No. I/2. Krapje: Javna ustanova Park prirode Lonjsko polje.

Hoffmann, R. 2008. Medieval Europeans and their Aquatic Ecosystems. V Beiträge zum Göttinger Umwelthistorischen Kolloquium 2007-2008, ur. B. Herrmann, 45-64. Göttingen: Universitätsverlag.

Hudoklin, A. 2008. »Naravovarstveni pogled na Vrbino. « Živi svet Vrbine, i-iii. Brežice: Agencija za radioaktivne odpadke, Lokalno partnerstvo.

Hudoklin, A. 1993. »Naravovarstveni pomen habitatov v spodnjem Posavju. « Acrocephalus (Spodnje Posavje) I4(6I): I77185 .

Vogrin, M. in A. Hudoklin. 1993. »Ptice ob spodnjem toku reke Save. «Acrocephalus 6I(1993): 19I-200.

Hrobat, K. 2009. »Folklora v vlogi označevanja vaških mej kot prostorskih vrzeli v onostranstvo: primer Rodika. « Studia mythologica Slavica XII: 207-222. 
Klenovšek, D. 2009. »Kvaka, a leti - kvakač. « Svetptic 15(2): 22-23.

Klenovšek, D. 200I. »Travniki ob Savi so še bogati. « Dolenjski list 52(27) (2006) (05. 07. 200I): II.

Klenovšek, D. 1999. »Ptice ob reki Savi. « Proteus 62(I) (sep. 1999): 30-34.

Kuhar, B. 1972. Odmirajoči stari svet vasi: poljudno znanstvena razprava. Ljubljana: Prešernova družba.

Koropec, J. 1977. »Krško v obdobju velikih slovenskih kmečkih vstaj. « Krško skozi čas: 1477-1977. Zbornik ob soo-letnici mesta, ur. L. Smrekar, 45-6o. Krško: Skupščina občine Krško.

Kronberg, H. 1839. »Die Schiffahre Sava in Krain. « Carniola 92(15. 3. I839): 366-367.

Lovrenčak, F. 1980. »Prst in rastje poplavnega sveta ob Krki. « Geografski vestnik: Geografske značilnosti poplavnih območij ob Krkipod Otočcem XX (1980) (198I): 95208.

Makarovič, M. 1960. »Delo etnografskega muzeja v Ljubljani v letih 1957-1959. « Slovenski etnograf $30(\mathrm{I}): 20 \mathrm{I}-207$.

Makarovič, G. 1991. »Prehrana v 19. stoletju na Slovenskem. « Slovenski etnograf XXXIIIXXXIV (1988-1990): 127-206.

Martinčič et al. 1999. Mala flora Slovenije: ključ za določanje praprotnic in semenk (3., dopolnjena in spremenjena izd. ). Ljubljana: Tehniška založba Slovenije.

Mencej, M. 2006. Coprnice so me nosile. Raziskava vaškega čarovništva v vzhodni Sloveniji na prelomu tisočletja. Ljubljana: Filozofska fakulteta, Oddelek za etnologijo in kulturno antropologijo.

Mlakar, V. 2015. Rastlina je sveta, od korenin do cveta. Tradicionalno znanje o rastlinskem svetu na Slovenskem. Ljubljana: V. Mlakar.

Mlekuž, D. 2009. Poplavne ravnice v novi luči : LiDAR in tafonomija aluvialnib krajin. Arheo (26): 7-22.

Mlinarič, J. 1977. »Krško in njegova gospoščina v srednjem veku. « Krško skozi čas: 14771977. Zbornik ob soo-letnici mesta, ur. L.
Smrekar, 25-44. Krško: Skupščina občine Krško.

Novak, V. 1947. Ljudska prehrana v Prekmurju. Etnografska študija. Ljubljana: Slovenski knjižni zavod.

Novak, V. 1957. »Vprašanje nabiralništva pri Slovencih. « Slovenski etnograf X (1957): 19-28.

N. N. 1893. »Gospodarske stvari: Pauliš Baraczko. «Dolenjske novice (I. 5. I893), IX (9): 69-70. www. dlib. si

N. N. 190I. »Pletarska šola. « Slovenski gospodar (28. II. I90I), 35 (48): 3. www. dlib. si

N. N. I893. »Domače vesti (Iz Krškega). « Dolenjske novice (I5. I. I893), IX (2): 13-I4. www. dlib. si

Papež, A. 2010. Uporaba divje rastočih rastlin $v$ prehrani. Neobjavljeno diplomsko delo, Oddelek za biologijo. Ljubljana: Biotehnična fakulteta Univerze v Ljubljani.

V 1 (1) gar, M. in Rihter, J. 2008. »Drnovo-Žabjek. 60. « Varstvo spomenikov 44: 60.

Pergar, M. in Rihter, J. 2008. »Vihre -Brežnice. 60. « Varstvo spomenikov 44: 297.

Plemel, V. I862. »Beitrage zur Flora Krain's. «Drittes Jabresheft des Vereines des krainischen Landes-Museums, $120-164$.

Pintar, L. I895. »Slovarski in besedoslovni paberki. « Letopis slovesnke matice, ur. A. Bartel, I-52. Ljubljana: Založila in izdala matica slovenska.

Pirc, F. 20I4. »Dvorec Grossdorf Velika vas. «Velika in Gorenja vas, Leskovec pri Krškem, ur. J. Spahalić, 163-169. Velika vas: Fotografika.

Počkar, I. (ur) 1998. Iz časov ječmenove kave: življenjepisi Štajercev in Kranjcev ob sotočju Krke, Save in Sotle. Novo mesto: Tiskarna Novo mesto.

Počkar, I. 2000. »Opekarstvo in opekarji v Brežicah. «Rast XI, 6(72), XI: 525-536.

Počkar, I. 200Ia. »Opekarstvo in opekarji v Brežicah. (Nadaljevanje iz prejšnje številke). Rast XII, I(73): 33-49. 
Počkar, I. 20orb. »Od svinje do votivnega prašička. « Rast XII, I(73): 576-589.

Počkar, I., 2009. »Kólnarji - lovilci in nabiralci premoga v Savi pri Brežicah, po toku navzgor in navzdol. « Gospa, če ni dobro, ni treba nič plačat: Brežice, trgovsko mesto (Brežiške študije; 3), ur. J. Škofljanec, 319387. Krško: Zavod Neviodunum.

Radinja, D. et al. 1976. »Geografske značilnosti poplavnega področja ob Pšati : I. del dolgoročne raziskovalne naloge »Geografija poplavnih področij na Slovenskem «, ki jo je prevzel Inštitut za geografijo SAZU. « Acta geographica I5: II-60.

Ravbar, M. 2008. »K nekdanjemu sijaju: letališče Cerklje ob Krki. «Revija obramba 40(6) (jul. 2008): 48-5I.

Rihter, J. 2006. \O prežitkih čarovništva na Drnovem in v okolici. «Profil: revija študentskega arheološkega društva, Študijsko leto 2005/2006, 3: 19-22.

Rihter, J. 2007. Vodic po kranjski vrbini, 25. september 2007. (Neobjavljeno gradivo, hrani ZVKDS OE Ljubljana Dopolnjena verzija).

Rihter, J. 2008. \O strahovih na Krškem polju - dve ledini Beli breg in Gauge. « Profil: revija študentskega arheološkega društva, Śtudijsko leto 2007/2008, 5: 2I-23.

Rihter, J. 2010. »Antropogene aktivnosti na holocenskih terasah južno od reke Save v zaledju Gorenjih in Dolenjih Skopic na Krškem polju in izbrani odstavki iz knjige spominov Uršule Vodopivec. « Profil: revija študentskega arheološkega društva, Študijsko leto 2009/2010, 6: 24-37.

Rihter, J. 20II. »Odnos do arheološke dediščine na Drnovem pri Krškem (Neviodunum) skozi časopisje od sredine 19. do sredine 20. stoletja. «Profil: revija študentskega arheološkega društva, Študijsko leto 2010/201I, 3-15.

Rihter, J. 20I 4. »Drobci iz preteklosti Velike vasi in Gorenje vasi v Leskovcu pri Krškem. «Velika in Gorenja vas, Leskovec pri Krškem, ur. J. Spahalić, 9-87. Velika vas: Fotografika.

Rihter, J. 2015. Drnovo pri Krškem: retrogradna analiza katastra, ustno izročilo, arheološka topografija in mitična pokrajina.

Neobjavljeno diplomsko delo. Oddelek za arheologijo. Ljubljana: Filozofska fakulteta Univerze v Ljubljani.

Rihter, J. 20I6a. »Gorenje/Dolenje cesarsko - ostanki kamnitih struktur iz časa regulacije reke Save. «Varstvo spomenikov 50-51: 58-59.

Rihter, J. 2016b. »Mrtvice in Vihre - Petrova škarpa (del obsavske vlečne poti med letoma 1853 in 1862 ). «Varstvo spomenikov 50-51: 15I-I52.

Rihter, J. 2016c. »Vihre - Turški brod pri Skopiškem zalivu. «Varstvo spomenikov 50-5I: 24I-242.

Rihter, J. 20ı6d. »Avstro-ogrsko vojaško strelišče topničarjev in vadbeni poligon letalskih sil JA/JLA. «Varstvo spomenikov 50-51: $247-249$.

Rihter, J. 20I6e. »Pliš-Zaroman. «Varstvo spomenikov 50-51: 249-250.

Rihter, J. 2017. »Območje jugovzhodne neviodunske vpadnice v ustnem izročilu. « Studia mythologica Slavica XX: 55-8I.

Ripšl, D. F. 2007. »Kronika fare Videm. « Med najlepše kraje slovenskega Štajerja šteje se župnija Videm : zbornik ob 85o-letnici prve pisne omembe pražupnije Videm ob Savi, ur. A. Črnelič Krošelj in M. Makarovič, I38I7I. Krško: Valvasorjev raziskovalni center Krško.

Rohrman, V. I899. »Prašičje pleme na Dolenjskem. « Kmetovalec: gospodarski list s podobami I6(2) (3I. OI. I899): 9-II.

Rutar, S. in A. Premerstein. 1899. Römische Strassen und Befestigungen in Krain mit Karten und Facsimilien. Wien: K. K. Central-Commission zur Erforschung und Erhaltung der kunst- und historischen Denkamale. 
Rutar, S. I899. »Rimska cesta $\gg$ AquileiaSiscia«. «Izvestja Muzejskega društva za Kranjsko 9(4): II3-II9.

Seručnik, M. 2009. »Reambulančni kataster za Kranjsko. « Kronika: časopis za slovensko krajevno zgodovino 57(3): 49I-504.

Snoj, M. 2009. Etimološki slovar slovenskih zemljepisnih imen. Ljubljana: Modrijan, Založba ZRC.

Sosič, B. 2000. »Gradivo o ljudski medicini v zapisih terenskih ekip slovenskega etnografskega muzeja. «Etnolog: glasnik Slovenskega etnografskega muzeja 10: 213254.

Stritar, A. 1990. Krajina, krajinski sistemi; Raba in varstvo tal v Sloveniji. Ljubljana: Partizanska knjiga.

Stritar, A. 1977. »Tla in podobe krajin v spodnjesavskem predelu Slovenije. « Lado Smrekar (urednik), Krško skozi čas: I4771977. Zbornik ob soo-letnici mesta, ur. L. Smrekar, 627-638. Krško: Skupščina občine Krško.

Smole, M. 1980. Graščina Šrajbarski turn. Ljubljana: Arhiv SR Slovenije.

Šebek, Ž. 2009. Krško - življenje z reko Savo. Krško: Založba Neviodunum.

Šribar, L. 20I8. »Kmetijsko zadružništvo. Zadružno gospodarjenje v Leskovcu pri Krškem na področju agrokulture. «Leskovec pri Krškem skozi čas, ur. J. Spahalić, 99-I47. Leskovec pri Krškem: Krajevna skupnost.

Šubic, P. 2018. Krškopoljski prašič bo glavna zvezda nove turistično-kulinarične ponudbe v Posavju (19. or. 2018). Dostopno: https:// agrobiznis. finance. si $/ 8863778$ ?cctest $\&$ (10. OI. 2019).

Teppey, J. 1971. »Dolga sobota kmetice z Drnovega. « Dolenjski list XXII(47) (II30), (25. II. 1971): 22.

Teppey, J. 1977. »Prijateljstvo z reko. « Dolenjski list XXVIII (44)(I475) (Iо. II. 1977): 29.
Umek, E. 1986. »Plovba po Savi in Ljubljanici v i8. stoletju. « Zgodovinski časopis $40(3)$, 233-286.

Umek, E. 1996. »Promet po Savi in mitnina v Krškem. « Gestrinov zbornik, 27I-278. Ljubljana: ZRC SAZU.

Valenčič, V. 1965. »Iz zgodovine naših gozdov. Dolenjski gozdovi v terezijanskem katastru. « Gozdraski vestnik XXIII: I8I192.

Valvasor, J. V. 2010. Slava vojvodine Kranjske, II. knjiga: Kratka topografija. Ljubljana: Zavod Dežela Kranjska.

Vrhovec, I. I895. »Čolnarji in brodniki na • Ljubljanici in Savi. «Slovenska matica IX: 97-I4I.

Valenčič, V. 1970. »Vrste zemljišč. « Gospodarska in družbena zgodovina Slovencev: Zgodovina agrarnih panog. Zv. I, Agrarno gospodarstvo, I3I-I 48. Ljubljana: Državna založba Slovenije.

Verbič, T. in B. Berič. 1993. »Struge reke Save • med Krškim in Brežicami v 19. stoletju. « Proteus 56(1993-1994): 327-333.

Verbič, T. 2004. »Stratigrafija kvartarja in neotektonika vzhodnega dela Krške kotline. I. del: Stratigrafija. «Razprave 45(3)(2004): 17I-225.

Šalehar, A. 2015. Krškopoljski prašič: iskanje ostankov, ohranjanje in osvežitev pasme v letih 19go-2003. Slovenj Gradec : Kmetijska založba.

Verbič, T. 2008. Kvartarni sedimenti, stratigrafija in neotektonika vzhodnega dela Krške kotline. Neobjavljena doktorska disertacija, Oddelek za geologijo.

Ljubljana: Naravoslovnotehniška fakulteta Univerze v Ljubljani.

Vrhovec, I. I895. »Čolnarji in brodniki na Ljubljanici in Savi. « Slovenska matica IX: 97-I 4I.

Vodopivec, U. 2008. Knjiga spominov (za Jerneja). Rokopis. Privatni arhiv. Neobjavljeno gradivo.

Wright, S. in S. L. Goodacre. 2012. Evidence for antimicrobial activity associated with 
common house spider silk. BMC Research Notes 5(326): I-6.

Zadravec, J. 1985. »Fragmenti iz ljudske medicine v severovzhodni Sloveniji. « Zbornik za zgodovino naravoslovja in tehnike 8, ur. F. Dominko, str. 127-136. Ljubljana: Slovenska matica Ljubljana.

Zadravec, J. 2000. »Ljudsko zdravilstvo v Prekmurju. « Etnolog: Glasnik Slovenskega etnografskega muzeja 10: 45-62.

Zakšek, J. 20r2. 》Milena Kuhar z Malenc, ki je ugledala luč sveta prvega januarja 1928. « Kostanjeviške novice. Glasilo občine Kostanjevica na Krki, marec(54): 29-33.

Zelko, I. 1985. »Prekmurska ledinska imena -in primerjava s Panonskoslovenskimi imeni. « Slavistična revija 33 (4) (oktoberdecember): 459-465.

\section{Leksikoni, spletne zbirke in slovarji}

KLDB 1937: Krajeuni leksikon dravske banovine: krajevni repertorij $z$ uradnimi, topografskimi, zemljepisnimi, zgodovinskimi, kulturnimi, gospodarskimi in tujskoprometnimi podatki vseh krajev dravske banovine. Ljubljana: Uprava Krajevnega leksikona dravske banovine.

Pleteršnik, M. Slovensko-nemški slovar: Dostop: www. fran. si. (4. 7. 2019).

Kramarič V. Fototeka SEM. 604 Fo037206. Drnovo pri Krškem. Med leti 1928 in 1947 (https://www. etno-muzej. si).

\section{Arhivsko gradivo}

SI ARS, AS 176, Franciscejski kataster za Kranjsko, k. o. Leskovec pri Krškem; mapni list VII, N o87(I824), abecedni seznam posestnikov $\mathrm{N} \circ 87$ PUA (24. 4. I825); zapisnik zemljiških parcel, $\mathrm{N} \circ 87 \mathrm{PS}$ (april I825), cenilni elaborat, NO 87PZ (26. 3. 1834 ).

SI ARS, AS 176, Franciscejski kataster za Kranjsko, k. o. Krška vas: mape (I824), zapisnik zemljiških parcel, $\mathrm{N}_{165}$ PS (9. 4. I825); abecedni seznam posestnikov, $\mathrm{N}$
I65 PUA (9. 4. 1825) in cenilni elaborat, $\mathrm{N}$ I65PZ (28. 4. 1833).

SI ARS, AS 176, Franciscejski kataster za Kranjsko, k. o. Drnovo; mapni listi (1824); abecedni seznam posestnikov, $\mathrm{N} 033$ PUA (I0. 4. I825); zapisnik zemljiških parcel, N 033 PS (10. 4. 1825), cenilni elaborat, NO ${ }_{33} \mathrm{PZ}$ (20. januar I833). 